\title{
LUÍS FERNANDO GOTARDE
}

\section{A filosofia da educação de William H. Kilpatrick}

\section{Versão Corrigida}

(A versão original encontra-se disponível na Biblioteca da Faculdade de Educação da USP)

Dissertação apresentada à Faculdade de Educação da Universidade de São Paulo para obtenção do título de Mestre em Educação.

Área de Concentração: Filosofia e Educação

Orientador: Prof. Dr. Marcos Sidnei Pagotto-Euzebio 
Autorizo a reprodução e divulgação total ou parcial deste trabalho, por qualquer meio convencional ou eletrônico, para fins de estudo e pesquisa, desde que citada a fonte.

Gotarde, Luis filosofia da educação de william H. Rilpatrick / Luís Fernando Gotarde; orientador Marcos Sidnei Pagotto-Euzebio. -- São Paulo, 2019.

$130 \mathrm{p}$.

Dissertação (Mestrado - Programa de Pós-Graduação Cultura, Filosofia e História da Educaçấo) -Faculdade de Educação, Universidade de são Paulo, 2019.

1. Rilpatrick. 2. Educaçăo Progressiva. 3. Democracia. 4. Self - Caráter - Ética. 5.

Pragmatismo. I. Pagotto-Euzebio, Marcos Sidnei, orient. II. Título. 
GOTARDE, Luís Fernando. A filosofia da educação de William H. Kilpatrick. 2019. 130 f. Dissertação (Mestrado) - Curso de Mestrado em Educação, Faculdade de Educação da Universidade de São Paulo, São Paulo, 2019.

Dissertação apresentada à Faculdade de Educação da Universidade de São Paulo para obtenção do título de Mestre em Educação.

Aprovado em:

Banca Examinadora:

Prof. Dr.

Instituição:

Julgamento:

Prof. Dr.

Instituição:

Julgamento:

Prof. Dr.

Instituição:

Julgamento: 
Aos meus alunos 
Agradecimentos

À minha esposa Samira, pelo amor, respeito, encorajamento e dedicação;

A Marcos Sidnei, pelas contribuições, confiança, encorajamento, compreensão e amizade nos momentos dificeis;

Aos amigos e familiares, pelo carinho e encorajamento;

Às colegas e amigas de Jarinu e de Louveira, pela amizade, companheirismo e encorajamento;

Aos colegas da pós-graduação, por suas colaborações e coleguismo;

Aos professores Darcisio Muraro (UEL), Jaime Cordeiro (USP) e Marcos Lorieri (UNINOVE) pelas valiosas contribuições para o trabalho;

E aos meus alunos, pelo carinho e compreensão. 
"Aprendemos o que vivemos. Aprendemos cada coisa conforme a aceitamos como nossa; e aprendemos na medida em que a consideramos importante" (KILPATRICK, 1941, p.146). 


\section{RESUMO}

GOTARDE, Luís Fernando. A filosofia da educação de William H. Kilpatrick. 2019. 130 f. Dissertação (Mestrado) - Curso de Mestrado em Educação, Faculdade de Educação da Universidade de São Paulo, São Paulo, 2019.

Este trabalho consiste em uma pesquisa bibliográfica que visa à exposição dos elementos essenciais da filosofia da educação de William Heard Kilpatrick. Buscou-se, também, averiguar de que modo esses elementos mantiveram-se pertinentes para o autor ao longo de sua trajetória intelectual. Metodologicamente, realizou-se a leitura das obras de Kilpatrick e da bibliografia pertinente. Ao final da pesquisa, constatou-se que no núcleo do pensamento kilpatrickiano está o princípio da permanente mudança da natureza, tributário do pensamento darwiniano. Esse princípio, o da mudança, ecoará no pensamento filosófico, pedagógico e psicológico de Kilpatrick. Seu pensamento é tributário, além de Charles Darwin, do pensamento de John Dewey, Charles S. Peirce, William James, Edward L. Thorndike e George H. Mead. Também constatou-se que Kilpatrick, ao longo da vida, realizara um movimento teórico ao encontro da integração indivíduo-sociedade, cujos passos foram: a) do ponto de vista da psicologia: a crítica à visão mecanicista de ser humano e a defesa de uma psicologia favorável ao desenvolvimento da criatividade humana e à relação ética entre pessoa e grupo; b) do ponto de vista da educação: a crítica à prefixação de conteúdo, à padronização da avaliação e ao autoritarismo; a defesa do respeito à personalidade e a defesa de uma educação concebida de forma atual e reflexiva; c) do ponto de vista ético-político: a defesa de uma sociedade democrática e a defesa do livre pensamento e da livre expressão da personalidade.

Palavras-chave: Kilpatrick. Educação Progressiva. Democracia. Self - Caráter - Ética. Pragmatismo. 


\begin{abstract}
GOTARDE, Luís Fernando. The philosophy of education of William H. Kilpatrick. 2019. 130 f. Dissertação (Mestrado) - Curso de Mestrado em Educação, Faculdade de Educação da Universidade de São Paulo, São Paulo, 2019.

This work consists of a bibliographic research that aims to expose the essential elements of William Heard Kilpatrick's philosophy of education. It also sought to know how these elements remain relevant to the author along his intellectual trajectory. Methodologically, it was made a reading of Kilpatrick's works and the relevant bibliography. At the end of the research, it noted that the Kilpatrick's thought core is the principle of permanent change of nature, tributary of Darwinian thought. This principle of change will echo in Kilpatrick's philosophical, pedagogical, and psychological thinking. His thinking is tributary, in addition to Charles Darwin, the thinking of John Dewey, Charles S. Peirce, William James, Edward L. Thorndike, and George H. Mead. It also noted that throughout his life, Kilpatrick did a theoretical movement towards the integration member-society, whose steps were: a) in the psychology point of view: the criticism of the mechanistic view of the human being and the defense of a favorable psychology to the development of the human creativity and the ethical relationship between person and group; b) in the education point of view: a critique of the prefixing of contents, the standardization of evaluation and authoritarianism; a defense of respect for personality and a defense of a current and reflexively conceived education; c) in the ethical and political point of view: a defense of a democratic society and a defense of the free thinking and expression of personality.
\end{abstract}

Keywords: Kilpatrick. Progressive Education. Democracy. Self - Character - Ethics. Pragmatism. 


\section{SUMÁRIO}

1.1.2 O pensamento de Kilpatrick por Fernando de Azevedo e

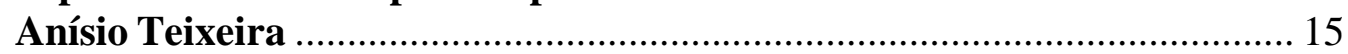

1.1.3 O pensamento de Kilpatrick por Dermeval Saviani .................................. 17

O PENSAMENTO DE KILPATRICK REVISITADO ................................. 19

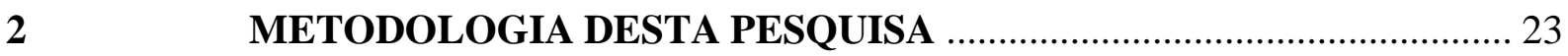

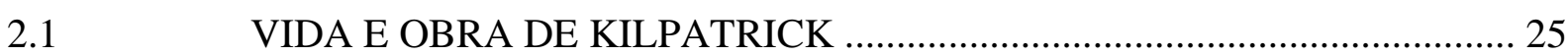

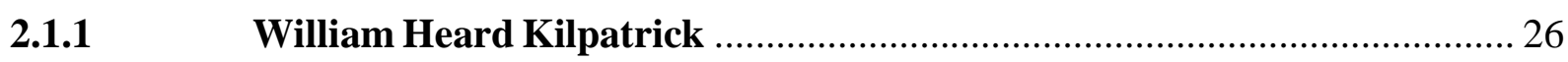

2.1.2 Origens da obra Método de Projeto .............................................................. 27

2.1.3 Interesse pela educação como objeto de investigação ............................... 28

2.1.4 John Dewey e a Universidade Columbia .............................................. 31

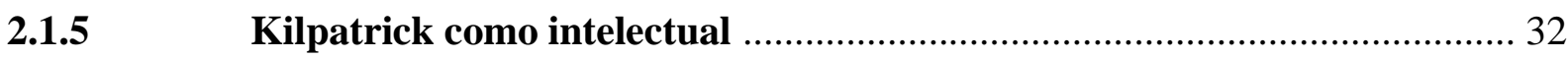

3 A MUDANÇA COMO PRINCÍPIO E A EDUCAÇÃO …....................... 37

PRAGMATISMO E HERANÇA DARWINIANA ........................................ 37

3.1.1 Kilpatrick e conceito deweyano de experiência ......................................... 38

3.2 O CERNE DO PROCESSO PEDAGÓGICO E A SUPERAÇÃO DA DICOTOMIA INDIVÍDUO-SOCIEDADE .................................................... 43

3.2.1 A centralidade do educando no paradigma pedagógico: distinções entre Dewey e Kilpatrick .......................................................... 44

3.3 PENSAR EDUCAÇÃO E SER HUMANO EM MOVIMENTO ..................... 47

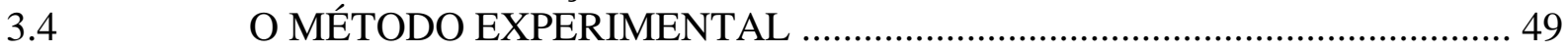

3.4.1 O método experimental: do laboratório para a vida …............................... 50

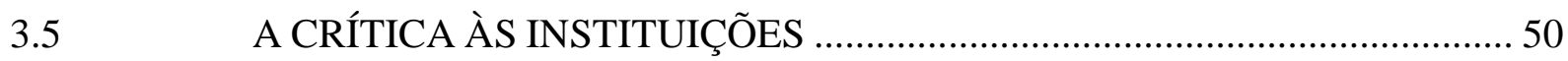

INDUSTRIALIZAÇÃO E INTEGRAÇÃO SOCIAL …................................. 51

A DEMOCRACIA COMO VIDA MORAL …............................................. 52

3.8 A MUDANÇA COMO PARADIGMA EDUCATIVO ................................. 54

3.8.1 A mudança como paradigma pedagógico ….......................................... 57

3.8.2 O papel da escola diante da atomização ético-política da sociedade .......... 58

3.8.2.1 A mudança como paradigma educacional-escolar: o currículo ........................ 62

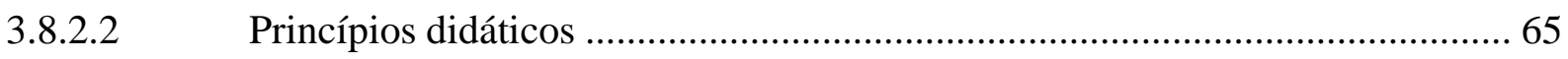

3.8.2.3 Método de Projeto: utilização do ato intencional no processo educativo ........ 69

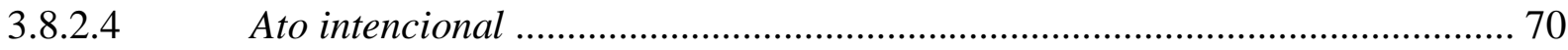


3.8.2.5 Educação democrática e para a democracia ................................................ 73

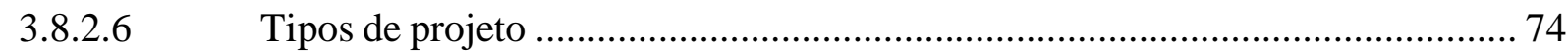

A MUDANÇA COMO PRINCÍPIO PSICOLÓGICO ............................ 76

$4.1 \quad$ A PSICOLOGIA DE THORNDIKE E A PEDAGOGIA PROPOSTA POR KILPATRICK …............................................................................. 76

4.1.1 Leis primárias e princípios e leis secundários da

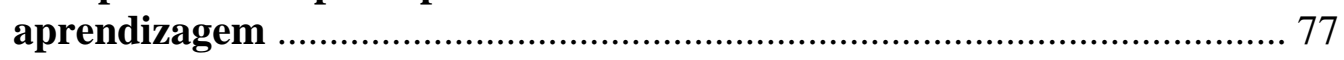

4.1.2 Leis e princípios de aprendizagem e o ato intencional ............................... 80

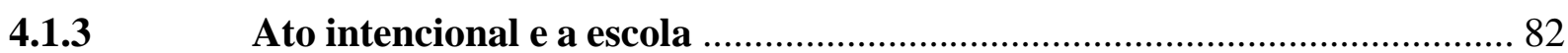

4.1.4 Ato intencional e a educação moral em Método de Projeto ......................... 82

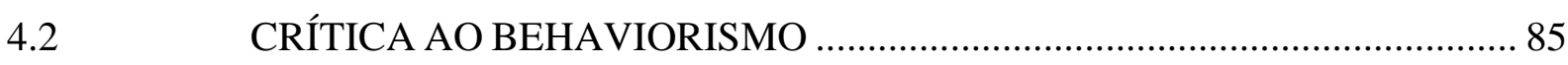

4.3 A PSICOLOGIA COMO RUPTURA DO PARALELISMO

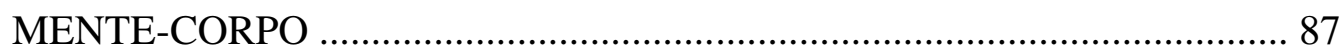

4.4 CRÍTICA À OBJETIVIDADE NEWTONIANA APLICADA ÀS

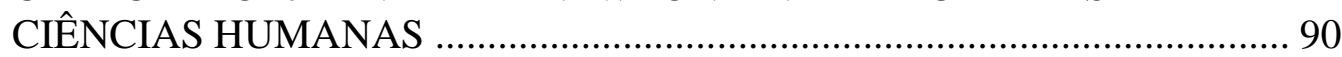

4.5 A EDUCAÇÃO PENSADA A PARTIR DA NOÇÃO MEADIANA DE SELF .......................................................... 91

A FORMAÇÃO DA IDENTIDADE PESSOAL …..................................... 92

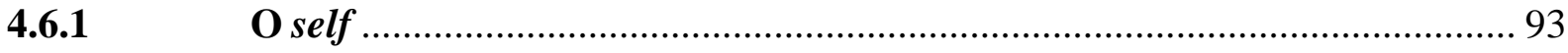

4.6.2 Estágios de desenvolvimento da identidade pessoal ................................ 94

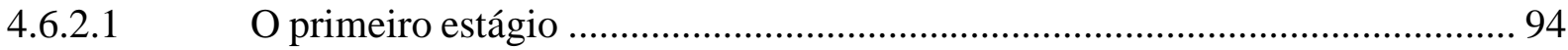

4.6.2.1.1 O processo de formação interna das coisas durante o primeiro estágio ......... 95

4.6.2.1.2 Surgimento da unidade interna do self ............................................................ 96

4.6.2.1.3 Surgimento e desenvolvimento simultâneo do self $e$ do other .......................... 96

4.6.2.1.4 O desenvolvimento da agência e do senso de dever moral durante o primeiro estágio ......................................................................................... 100

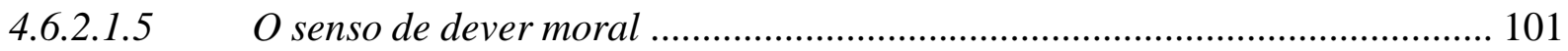

4.6.2.1.6 A moral tradicional na formação da identidade pessoal ............................... 102

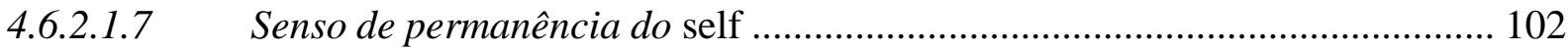

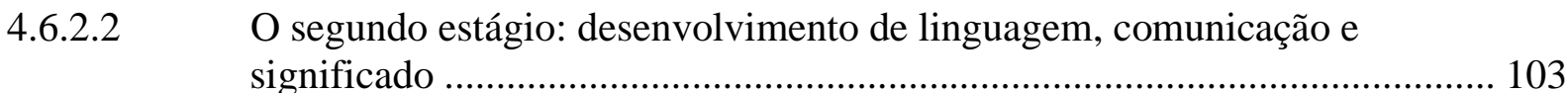

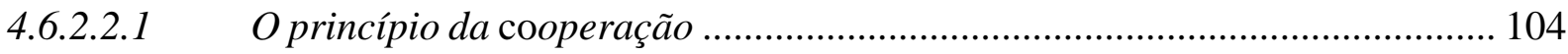

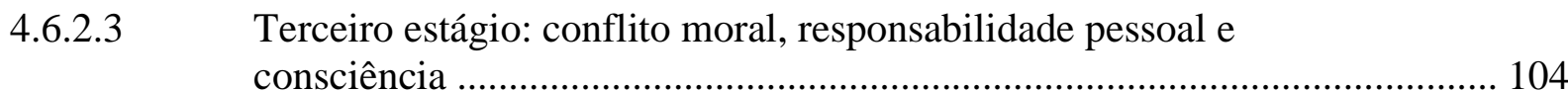

4.6.2.3.1 Consciência, conflito moral e responsabilidade ............................................. 106

4.7 PRINCÍPIO GERAL DA APRENDIZAGEM .......................................... 107

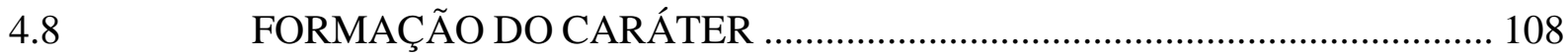

4.8.1 Níveis de agência moral …......................................................................... 110 
O PROCESSO SELF-OTHER COMO PRINCÍPIO NO DESENVOLVIMENTO DA CULTURA E DAS IDENTIDADES PESSOAIS

4.9.1 O processo histórico de complexificação da cultura e das identidades pessoais

4.9.2 A interdependência indivíduo-sociedade no que tange à moral e à crítica à cultura

INDIVIDUALIDADE 118

4.11

LIBERDADE

Liberdade como autodeterminação 119

4.11.2 Liberdade vista sob o princípio universal de causalidade 120

4.11.3

Liberdade $x$ preconceito 122

4.11.4

Liberdade por meio das instituições 123

5. 


\section{INTRODUÇÃO}

A intenção primeira deste trabalho é a exposição da filosofia da educação de William Heard Kilpatrick, pensador estadunidense cuja produção mais contundente concentra-se na primeira metade do século XX. Em suma, busca-se explicitar o que se considera ser o essencial dessa filosofia e as bases que a fundamentam.

Kilpatrick, longe de ser considerado um autor que carece de originalidade, pode ser reconhecido como alguém que pensa de forma atual o papel da educação oferecida pela escola ou por outras instituições e, desse modo, sua originalidade manifestar-se-á enquanto pensador da e na práxis. Essa característica pode ser evidenciada pelo fato de grande parte de sua obra ser composta por textos que trazem uma parte de fundamentação teórica e outra que trata das respectivas implicações de forma atual para a educação.

Este trabalho busca explicitar uma - e certamente não a única - compreensão das ideiaschave da filosofia de Kilpatrick, o que será feito por meio de uma exposição dividida em temas e aspectos cuja origem comum é o princípio da mudança.

O presente estudo limitar-se-á àquilo que no referido autor considera-se como essencial para que se efetive a compreensão de sua proposta de educação e de sociedade.

Embora, por exemplo, haja registros da implementação de suas ideias em escolas de seu país de origem - inclusive alguns que desaprovam a metodologia, conforme descreve Knoll (2018) em Cometi um erro: William H. Kilpatrick e o Método de Projeto - a presente pesquisa manterá seu caráter bibliográfico, pois um possível levantamento e análise de ações de implementação pedagógica seriam suficientes para exigir um trabalho de campo e mesmo uma pesquisa documental, o que extrapolaria o escopo deste trabalho.

Mas, quem é Kilpatrick e como sua obra foi difundida no Brasil?

Durante o período que abrange o final do século XIX e o início do XX, o Brasil passou por profundas mudanças políticas, econômicas e sociais ligadas: à reestruturação do país após a Guerra do Paraguai (1865-1870), à abolição da escravidão negra; ao advento da República; e às consequências sociais e econômicas da crise mundial ocorrida no final do século XIX, que atingiu duramente o setor agrário e impulsionou a migração do homem do campo para a cidade e estimulou a industrialização e a busca de mão de obra qualificada em larga escala (LEMME, 2005, p.164).

Na verdade, a industrialização e a urbanização continuarão a se expandir após esse período - especialmente com a eclosão da Primeira Guerra Mundial - em virtude da escassez 
de produtos estrangeiros manufaturados, até então, disponíveis ao mercado brasileiro. Além disso, na década de 1920, a taxa de analfabetismo havia ultrapassado os 83\% (ibidem, p.164).

Diante desse quadro e da pressão tanto por parte de industriais que desejavam a modernização do país, quanto de intelectuais e de grandes educadores, houve uma série de movimentos por reformas que não apenas a econômica e a política, mas, sobretudo, a cultural. O movimento da escola nova no Brasil viria ao encontro dessas necessidades.

O movimento da escola nova, em si, foi um movimento presente em vários países. Dentre os educadores mais influentes, estavam, para citar alguns: Claparède (1873-1940), Binet (1857-1911), Decroly (1871-1932), Montessori (1870-1952), Dewey (1859-1952), Wallon (1879-1962), Thorndike (1874-1949) e Kilpatrick (ibidem, p.169).

No Brasil, Kilpatrick ganhou notoriedade com esse movimento e principalmente com o Manifesto dos Pioneiros da Educação Nova, publicado em 1932, redigido por Fernando de Azevedo.

Anísio Teixeira, um dos signatários do Manifesto, fora aluno de Kilpatrick e de Dewey na Universidade de Columbia. Em relação a ambos, Anísio notara, inclusive, que cada um se colocava de modo peculiar acerca da questão da educação. Diz, Anísio: "Dewey diz o que se deve fazer e Kilpatrick o como se deve fazer, em educação.” (TEIXEIRA, 1930, p.34, nota de rodapé apud PAGNI, 2008, p.22-23).

A partir do comentário de Anísio Teixeira, sugere-se que há uma maior preocupação didática em Kilpatrick se comparado a Dewey.

Contudo, houve mais de uma interpretação feita pelos pioneiros acerca da escola nova e acerca do próprio movimento em sua vertente brasileira, a exemplo de Anísio Teixeira e Fernando de Azevedo, conforme Pagni (2000, p.35-36).

\subsection{O PRAGMATISMO DEWEYANO NO BRASIL}

No Brasil, as iniciativas pela reforma da educação e do ensino tiveram início já em 1909, com a publicação de Educação, um livro que preconizava a renovação escolar e que fora escrito por Antônio Carneiro Leão, um intelectual pernambucano.

Cerca de onze anos mais tarde, no Estado de São Paulo, a primeira dessas reformas regionais de ensino seria feita por Sampaio Dória. E a partir de então, a década de 1920 seria marcada por uma série de mudanças na área. 
Em 1922, Lourenço Filho é chamado pelo Estado do Ceará para realizar a segunda dessas reformas. Na Bahia, em 1924, houve a reforma realizada por Anísio Teixeira, após seu retorno da Universidade de Columbia.

Por sua vez, outros educadores tomaram a mesma iniciativa: José Augusto Bezerra de Menezes, no Estado do Rio Grande do Norte, nos anos de 1925 a 1928; Antônio Carneiro Leão, entre 1922 e 1926, no antigo Distrito Federal e, posteriormente, em 1928, no Estado de Pernambuco; e nos anos de 1927 a 1928, Lisímaco Costa no Estado do Paraná, Francisco Campos em Minas Gerais e Fernando de Azevedo, no antigo Distrito Federal, até então a Capital da República (LEMME, 2005)

Nesse contexto brasileiro de modernização do ensino, durante década de 1920, a recepção do pragmatismo deweyano ganhou ênfase. No final dessa década, Lourenço Filho publicaria Introdução ao Estudo da Escola Nova, um livro que seria o resultado da organização de suas aulas de psicologia e pedagogia ministradas na Escola Normal de São Paulo (ASSIS; CAMPOS; LOURENÇO, 2002, p.18). Nessa obra, estão presentes apontamentos importantes sobre o pensamento de William James, John Dewey, Edward Lee Thorndike e William H. Kilpatrick.

Lourenço Filho, assim como outros escolanovistas, inspirara-se no movimento estadunidense da educação progressiva, que, historicamente, fora um dos desdobramentos do progressivismo americano. Esse, por sua vez, é reconhecido como um amplo esforço social de busca e implementação do ideal americano de democracia em meio à civilização urbanoindustrial que se formava a partir da segunda metade do século XIX.

A expressão "educação progressiva", na verdade, representava a face educacional do progressivismo americano. Desse modo, historicamente a educação progressiva começou como progressivismo em educação e consistiu no esforço de se utilizar da educação escolar como um meio de transformação radical da sociedade em seus aspectos sociais e culturais (CREMIN, 1964, p.viii). Seus partidários viam na educação progressiva várias justificativas.

A primeira é a adequação tanto do projeto pedagógico quanto da função da escola para assumir temas diretamente relacionados à saúde, à vocação profissional e à qualidade de vida familiar e da comunidade.

A segunda, a aplicação em sala de aula dos princípios pedagógicos derivados das ciências sociais e da nova pesquisa científica em psicologia.

A terceira justificativa, a dialogicidade curricular com as necessidades de cada grupo social que ingressa na escola, ou seja, a ideia de uma educação para todos. Principalmente em 
relação a essa ideia, os progressistas afirmavam que não somente os métodos, mas muito do significado da educação deveria mudar.

E finalmente, o progressivismo implicava a crença radical de que a cultura poderia ser democratizada sem ser vulgarizada e também a crença de que todos poderiam partilhar não somente dos benefícios das novas ciências, mas também da busca pelas artes (CREMIN, 1964, p.ix).

Mas, de que modo intelectuais como Lourenço Filho, Fernando de Azevedo e Anísio Teixeira introduziram a educação progressiva no Brasil? E de que modo Kilpatrick foi interpretado pelo pensamento crítico à escola nova, como, por exemplo, o de Dermeval Saviani?

\subsubsection{O pensamento de Kilpatrick por Lourenço Filho}

A obra Filosofia da Educação de Kilpatrick é citada em Introdução ao Estudo da Escola Nova por Lourenço Filho quando este, pautado na perspectiva de ensino por projetos, trata do papel desempenhado pelas atividades intencionais na promoção de uma experiência educativa sob o regime de liberdade.

A citação que segue é um ponto importante dessa obra de Lourenço Filho, pois o autor reúne num único parágrafo algumas ideias-chave das filosofias de Kilpatrick e de Dewey, tanto quanto evidencia a filiação teórica de Kilpatrick em relação a Dewey. Diz, Lourenço Filho:

as atividades intencionais, ou de propósitos definidos, reclamam porções unificadas da experiência; só assim a criança será levada do desejo a intenções conscientes, e dessas intenções a propósitos mais amplos, na forma de aspiração e ideais. Este modelo é que constitui o cerne da concepção educativa de Dewey. Ter propósitos representa um bem em si, pois projetar e realizar será viver em liberdade. "As situações sociais que animam a estruturação e a realização de propósitos - ajunta Kilpatrick - levam a respeitar a personalidade, porque permitem a cada pessoa escolher e realizar aquilo que aprecia, por lhe parecer mais digno, mais capaz de contribuir para a expansão de sua vida segundo os estímulos de seu coração. Ser respeitado nessa capacidade de projetar e realizar é a função da liberdade que caracteriza o estilo de vida democrático". E Kilpatrick encerra esse trecho citando as palavras de Whitehead: 'A essência da liberdade é a praticabilidade dos propósitos que formulamos' (LOURENÇO FILHO, 2002, p.299).

A presença de Kilpatrick no pensamento escolanovista por meio de Lourenço Filho se dá, novamente, quando esse, na mesma obra, expõe os princípios gerais da escola nova, dos quais, para este trabalho, foi transcrito o primeiro. Diz, Lourenço Filho: “O primeiro princípio, porque constante em todos os sistemas renovados, é o respeito à personalidade do educando ou o reconhecimento de que deverá ele dispor de liberdade.” (ibidem, p.356-357). 
Esse princípio está intimamente ligado tanto à citação anterior quanto àquilo que Kilpatrick escreve alhures em Filosofia da Educação:

a educação até agora discutida [na obra em questão] é uma educação pensada no sentido de libertar totalmente a personalidade do aprendiz para a vida plena, para o melhor e mais independente exercício de todos os seus poderes, para o controle de seu próprio destino. Eis o que consideramos como o verdadeiro respeito pela personalidade (KILPATRICK, 1951, p.121, tradução nossa).

Para Kilpatrick, o respeito pela personalidade é o pilar não somente da educação, mas também da democracia, pois:

o espírito da democracia enquanto modo de vida é visto como a obrigação moral de respeitar a personalidade como tal. No que se segue, este princípio, do respeito à personalidade, é aceito como a essência primária do modo de vida democrático, sua concepção dominante, seu âmago, o critério pelo qual julgamos se qualquer medida proposta é ou não é coerente com o espírito democrático (ibidem, p.138-139, tradução nossa).

O respeito pela pessoa humana e ao livre pensamento como evidência da educação democrática também fora exposto em A Democracia e o Respeito à Personalidade, onde Kilpatrick argumenta que a democracia, dentro ou fora da escola,

caracterizar-se-á pela maior variabilidade em interesses, atividade, expressão e realizações. Se a comunicação de ideias for livre, tais diferenças tenderão a ser reconhecidas e aproveitadas cada vez mais pelo grupo em sua totalidade (idem, 1942, p.30).

É notória, de fato, a filiação teórica Dewey-Kilpatrick-Lourenço Filho, assim como a aproximação filosófica desses autores com a do movimento escolanovista.

\subsubsection{O pensamento de Kilpatrick por Fernando de Azevedo e Anísio Teixeira}

Fernando de Azevedo e Anísio Spínola Teixeira são outros pensadores importantes do pensamento escolanovista brasileiro. No entanto, as interpretações do pragmatismo feitas por ambos são distintas.

Pagni (2000, p.35-36) considera que em Fernando de Azevedo o pragmatismo deweyano é lido a partir de uma forte influência da sociologia de Durkheim e da psicologia experimental, na qual, por sua vez, também se apoiara Kilpatrick quando elaborou Método de Projeto, em 1918, e Fundamentos do Método: Diálogos Informais sobre Ensino, em 1925.

Anísio Teixeira, por sua vez, também se apropriara do pragmatismo de Dewey, mas, segundo Pagni (2000), o fizera de modo a valorizar seu sentido pedagógico e fílosófico. E, além 
disso, ao mesmo tempo em que endossara um conceito de democracia diferente do conceito de democracia defendido por Azevedo, Anísio Teixeira desempenhou um papel crítico dentro do movimento.

Tanto Kilpatrick quanto Dewey parecem fundamentar o pensamento de Fernando de Azevedo no que tange ao texto do Manifesto, especialmente em sua primeira parte. Pagni afirma que os princípios pedagógicos e didáticos presentes no Manifesto, os quais visam à aprendizagem dos educandos pelo trabalho, pelo auto ajustamento ao progresso material e espiritual e por sua ação na sociedade, parecem ter sido formulados, principalmente,

a partir da filosofia da educação de John Dewey e da psicologia experimental interpretada por William Heard Kilpatrick. De um modo geral, a filosofia da educação de Dewey, conjuntamente com a concepção de aprendizagem de Kilpatrick, era entendida ou traduzida como um conjunto de métodos e princípios pedagógicos à época (ibidem, p.127).

Anísio Teixeira, por sua vez, enquanto elucida seu próprio posicionamento político no prefácio de Educação Progressiva: Uma Introdução à Filosofia da Educação, de 1934, expõe sua herança evolucionista e sua filiação teórica aos pensamentos de Dewey e de Kilpatrick. Também expressa o significado do termo "progressiva", presente no título do livro, o qual, de certo modo, distancia-o da visão positivista defendida por Fernando de Azevedo. Nas palavras de Anísio:

\footnotetext{
Alguns dos aspectos fundamentais da teoria de educação para uma civilização democrática e dominada pela ciência, são estudados neste pequeno livro.

O pensamento do autor não tem preocupações de originalidade. Filia-se ao dos modernos educadores e, mais diretamente, ao do grupo que reconhece, como sua principal figura, a do filósofo John Dewey.

A este e a Kilpatrick confessa-se profundamente devedor, embora assuma a responsabilidade exclusiva da forma de apresentação das ideias, das lacunas e das possíveis inexatidões deste trabalho.

Quanto ao título - 'Educação progressiva' - não se veja aí nenhuma referência ao termo 'progresso', na sua acepção entusiástica de crença, mas simplesmente a equivalência, no campo social, do termo 'evolução', no campo biológico. Educação em mudança permanente, em permanente reconstrução, buscando incessantemente reajustar-se ao meio dinâmico da vida moderna, pelo desenvolvimento interno de suas próprias forças mais bem analisadas, bem como pela tendência de acompanhar a vida, em todas as suas manifestações (TEIXEIRA, 1934, prefácio).
}

Anísio Teixeira foi responsável pela tradução para a língua portuguesa de algumas obras de Dewey, como A criança e o programa escolar (DEWEY, 1980a) e Interesse e esforço (DEWEY, 1978). Seu trabalho também se deu no âmbito da interpretação, quando, por exemplo, escreve A Pedagogia de Dewey, de 1978. 
Nesse texto, Anísio Teixeira faz referência ao conceito deweyano de educação, segundo o qual, educação é “o processo de reconstrução e reorganização da experiência, pelo qual lhe percebemos mais agudamente o sentido, e com isso nos habilitamos a melhor dirigir o curso de nossas experiências futuras." (TEIXEIRA, 1978, p.17).

Teixeira também se inspirou no pensamento de Kilpatrick ao se coadunar com certas ideias-chave desse autor, como, por exemplo, a concepção de educação em permanente mudança e a concepção de formação do caráter por meio da ação da consciência de si enquanto indivíduo livre e responsável e pela busca do próprio reajustamento ao meio social.

São, essas ideias, basilares, por exemplo, na obra Educação para uma Civilização em Mudança, uma das poucas publicações de Kilpatrick disponíveis em língua portuguesa - além de A Democracia e o Respeito da Personalidade e A Filosofia da Educação de Dewey -, obra, essa, que traz importantes questionamentos e apontamentos que são pertinentes para se pensar a educação tanto na época quanto posteriormente.

Teixeira também se coaduna com o princípio de que a educação é ao mesmo tempo parte e o próprio processo da vida, em todas as suas manifestações. Princípio, esse, que remete a um dos objetivos da educação propostos tanto por Dewey quanto por Kilpatrick e que pressupõe uma escola que deve proporcionar meios que possibilitem ao indivíduo tornar sua vida mais rica em conteúdos e significados.

\subsubsection{O pensamento de Kilpatrick por Dermeval Saviani}

Em Escola e Democracia, Saviani (2008, p.35) afirma que, ao mesmo tempo em que acusa o ensino tradicional de ser pré-científico, a escola nova promove uma falsa crença de cientificidade em seus adeptos.

O termo pré-científico, segundo Saviani, fora cunhado por Kilpatrick em Educação para uma Civilização em Mudança. Em outras palavras, o autor brasileiro, citando especificamente essa obra, questiona a afirmação de Kilpatrick acerca da suposta não-cientificidade do ensino tradicional, ensino, esse, supostamente fundado na própria ciência moderna.

Em suma, Kilpatrick consideraria o método herbartiano um método pré-científico, pois, segundo Saviani, o método tradicional, considerado como pré-científico por Kilpatrick e pela escola nova, é, na verdade, “o método expositivo, [...] cuja matriz teórica pode ser identificada nos cinco passos formais de Herbart." (ibidem, 35).

Esses cinco passos propostos por Herbart, por sua vez, correspondem ao método científico indutivo formulado por Francis Bacon, filósofo empirista e importante pensador da 
ciência moderna (ibidem, 36-37). Uma aula que seguisse os cinco passos herbartianos poderia ser, hipoteticamente, exemplificada, como diz Saviani, por um aluno que está a realizar exercícios, e, portanto, a passar por esses passos, a saber: a) preparação - recordação da lição anterior, do conhecido; b) apresentação - quando ao aluno é exposto um novo conhecimento que lhe cabe assimilar; c) comparação e assimilação - que por comparação com o conhecimento velho, o novo é identificado e assimilado; d) generalização - o aluno é capaz de identificar os fenômenos correspondentes àquele conteúdo apreendido; e) aplicação - por meio de exemplos novos o aluno demonstra se ele aprendeu ou não. Para Saviani, Kilpatrick, ao considerar como pré-científico o ensino tradicional herbartiano, consequentemente consideraria como tal o método baconiano.

Contudo, a crítica de Saviani está inserida em uma crítica mais ampla e dirigida, na verdade, à escola nova. E o livro de Kilpatrick, nesse caso, seria uma obra representativa desse pensamento (Cf. SAVIANI, 2008, p.34-37).

Saviani, na referida obra, não considerou a necessidade de realizar uma explanação histórica sobre o conceito de ciência. Não é preciso salientar que esse conceito não é unânime entre as filosofias, mesmo entre filosofias contemporâneas; a partir disso, o que dizer, então, de autores como Saviani e Kilpatrick que possuem perspectivas distintas de realidade? Independentemente de o conceito de ciência ser ou não comum a Saviani e Kilpatrick, esse último, para afirmar que não há ciência no método educacional tradicional, também não realizara uma argumentação prévia que justificasse a qualificação da pedagogia herbartiana como pré-científica. De fato, uma argumentação nesse sentido seria importante para explicitar o que Kilpatrick considera como ciência.

Quanto ao livro Educação para uma Civilização em Mudança em si, entre outras questões feitas por Kilpatrick, a mais contundente é: qual é a tarefa da educação diante do diagnóstico de que a civilização está em acelerada mudança e que há um hiato entre o nível de desenvolvimento tecnológico e a capacidade de o ser humano lidar eticamente com o produto desse desenvolvimento?

De antemão, pode-se dizer que a discussão presente nessa obra referencia, ao mesmo tempo, um importante paradigma da educação e um dos princípios do pragmatismo, a saber: o de que a natureza está em constante transformação e, como não há ruptura entre natureza e cultura, essa também se encontra em transformação.

De posse desse princípio e diante do impasse acerca da suposta pré-cientificidade do método tradicional, não se poderia argumentar em favor da transitoriedade da própria definição 
de ciência? Ou seja: se o método científico, como produto cultural, também está em transformação, como definir o que é científico ou pré-científico?

De todo modo, no que tange ao ensino brasileiro em toda sua história, uma das teses de Saviani é a de que quando mais se falou em educação democrática, menos democrática foi a escola, e essa escola antidemocrática - ou para as elites, segundo Saviani - é uma herança do movimento da escola nova no Brasil. Vale lembrar que Saviani afirma não desejar, com Escola e Democracia, assumir uma postura anti-Manifesto dos Pioneiros. O próprio Anísio Teixeira é citado como uma figura de referência no debate educacional, segundo Saviani:

somos, pois, herdeiros de Anísio Teixeira. Dizia ele, em 1947, por ocasião da discussão do capítulo de Educação e Cultura da Constituição do Estado da Bahia: 'Sobre assunto algum se falou tanto no Brasil, e em nenhum outro, tão pouco se realizou. Não há, assim, como fugir à impressão penosa de nos estarmos a repetir'. E exatamente porque tão pouco se realizou, somos forçados a continuar insistindo nos pontos que Anísio, segundo seu próprio testemunho, se cansara de repetir. Sua luta de ontem é, ainda, a nossa luta de hoje (SAVIANI, 2008, prefácio à $33^{\text {a }}$ edição).

Ressalta-se que este trabalho não pretende examinar a educação em seu processo de implementação, ou seja, enquanto política pública, mas, sim, a educação enquanto concepção. Desse modo, não se considerou necessário ultrapassar, neste trabalho, os limites de uma descrição sumária acerca das concepções que alguns dos atores do período dentro do qual ocorreram as reformas educacionais citadas anteriormente e referenciadas por Teixeira e Saviani nessa citação. O que se considera relevante aqui é o levante de conceitos e a exposição de argumentos que conduzam à compreensão do pensamento de Kilpatrick, que é o objeto deste estudo.

\subsection{O PENSAMENTO DE KILPATRICK REVISITADO}

Kilpatrick tem muito em comum com os autores escolanovistas, não somente em virtude de semelhanças pontuais; mas, como visto, o próprio cerne do pensamento kilpatrickiano se faz presente, por exemplo, nas filosofias da educação de Anísio Teixeira, de Lourenço Filho e, de certo modo, na de Fernando de Azevedo.

Como foi dito, a escola nova foi um movimento multifacetado, tanto em relação aos educadores que o idealizaram quanto em relação a seus intérpretes. Apesar disso, a questão que se deve ter em mente quando se pensa Kilpatrick ou mesmo a escola nova é o quanto há de protagonismo no e do educando enquanto sujeito da aprendizagem. 
Tomando esse questionamento como ponto central do pensamento do autor, é notório que esse elemento, o protagonismo subjetivo, esteja circunscrito a outros conceitos em função do objetivo com o qual o autor produziu determinada obra. Se o escopo deste trabalho é justamente levantar elementos essenciais de Kilpatrick, dentre os quais certamente se destacam tanto a natureza quanto o nível do protagonismo do educando, é preciso, consequentemente, o estudo de várias obras do autor, visto que há elementos importantes de seu pensamento que não estão presentes com tanta ênfase, por exemplo, em Educação para uma Civilização em Mudança.

Beineke (1995, p.142, tradução nossa) chega a afirmar que Educação para uma Civilização em Mudança fora o "mais criativo, inovador e radical pensamento sobre escolas, currículo e sociedade" desenvolvido por Kilpatrick. De fato, a obra trouxe para o contexto da época elementos que, décadas depois, ainda se constituiriam valioso material crítico para se pensar a educação numa sociedade cujo futuro é incerto.

Porém, por mais profícua e inovadora que seja essa obra, ela não encerra a totalidade do pensamento kilpatrickiano, mesmo porque Identidade Pessoal e Civilização: um estudo do processo self-other ${ }^{1}$ difere de Educação para uma Civilização em Mudança tanto em termos de temática quanto pela matriz teórica predominante.

Mesmo sendo menos "criativa", Identidade Pessoal e Civilização é uma obra basilar para a compreensão do autor, a qual traz como temática a relação entre sociedade e indivíduo e de que modo, por meio da linguagem, ambos se tornaram constitutivos um do outro. Em Identidade Pessoal e Civilização, Kilpatrick explicita sua interpretação da psicologia de George

\footnotetext{
${ }^{1}$ Originalmente, em inglês: self-other process.

Ainda em relação à tradução, destaca-se que, primeiramente, toda a terminologia utilizada por Kilpatrick referente a conceitos meadianos será, neste trabalho, utilizada em sua versão portuguesa e segundo a nomeação dada por Kilpatrick, que é o autor de destaque, com exceção dos termos self e other, que, por razões de significado, serão mantidos em inglês. O termo self, especificamente, foi mantido em inglês inclusive por Casagrande (2014) e Sass (1992); o termo other, por sua vez, será mantido em inglês sob duas justificativas: a de referenciar o conceito meadiano de outro generalizado (generalized other) e a de evitar um "choque linguístico" quando em sua utilização na expressão self-other. Nos casos em que Kilpatrick utiliza os termos self e other em contextos que sugerem significados diferentes dos cunhados por Mead, ambos serão traduzidos, respectivamente, como "eu" e “outro". Desse modo, serão utilizados no corpo do texto e nas citações os termos e expressões:
a) self, tal como o utiliza Mead;
b) other para se referir a generalized other, em Mead;
c) eu interno para se referir ao $I$, em Mead;

d) outro interno para se referir a me, em Mead;

Em segundo lugar, destaca-se que, embora não seja o caso da expressão self-other process, Kilpatrick, ao longo de Identidade Pessoal e Civilização, utiliza frequentemente a expressão self-other no lugar de utilizar somente self, visto que, o autor, de posse da psicologia meadiana, concebe tanto o desenvolvimento quanto a própria possibilidade de existência do self como condicionados a um processo social, de interação pessoa-ambiente. Nesse sentido, a frequente utilização da expressão self-other no lugar de self evidencia, supostamente, a intenção do autor em explicitar a natureza social do self.
} 
Herbert Mead ao mesmo tempo em que aproxima ainda mais do campo da educação o pensamento desse autor.

É um exemplo de como uma obra ocasionalmente pode não tratar o pensamento integral de um autor, pois em Educação para uma Civilização em Mudança não havia qualquer referência direta à Mead. Essa viria anos mais tarde, em Remaking the Curriculum, quando, por exemplo, Kilpatrick trata da natureza social do self e traz um elemento fundamental para se pensar a questão do determinismo ao afirmar que: "[a] identidade pessoal é uma realização individual [...] e demanda um contexto social. [...] O próprio self, o lugar mais íntimo da própria identidade, é socialmente construído e condicionado." (KILPATRICK, 1936, p.42, tradução nossa).

O conceito meadiano de self, presente em Remaking the Curriculum (1936), não aparece em Educação para uma Civilização em Mudança (1926), e a ausência desse conceito pode induzir o leitor a uma interpretação limitada do pensamento do autor, interpretação, essa, circunscrita a apenas o conteúdo daquela obra, a um período da vida de Kilpatrick ou mesmo a um tipo de enquadramento ético-político prefixado.

Aparentemente, o próprio biógrafo de Kilpatrick comete um equívoco em And there were giants in the land: the life of William Heard Kilpatrick (1995), quando afirma que Kilpatrick em certo momento rompera com o pensamento behaviorista para se apropriar do pensamento de G. H. Mead. Para tanto, Beineke apoia-se na exposição argumentativa presente em Identidade Pessoal e Civilização, porém, em certa medida, ignora o exposto em Filosofia da Educação.

Beineke (1995, p.313) afirma textualmente que na obra Identidade Pessoal e Civilização Kilpatrick não somente rejeita o behaviorismo psicológico como essa rejeição seria reiterada em Filosofia da Educação. Porém, em Filosofia da Educação, Kilpatrick deixa claro que não rejeita o behaviorismo como um todo, mas antes o coloca em seu lugar enquanto psicologia cujo alcance encontra-se circunscrito ao estudo e à descrição do comportamento humano em seus níveis mais elementares.

Pois, bem. Como ler Kilpatrick?

Como proposto anteriormente, a intenção deste trabalho é compreender a filosofia da educação de Kilpatrick, o que pressupõe uma tentativa de trazer à luz aquilo que o autor pensou. Diante dessa tarefa, buscou-se uma organização de leitura e de exposição que, diante do pensamento do autor, favorecesse a correlação de conceitos.

O que se buscou com este trabalho, portanto, foi um estudo dos textos do autor; para tanto, tentou-se ser filosófico e deixar que Kilpatrick falasse. 
O leitor encontrará este trabalho dividido como se segue.

O item dois explicita a metodologia empregada na pesquisa, a qual busca fazer a contextualização histórica do pensamento de Kilpatrick por meio de uma breve descrição tanto da vida do autor quanto das obras mais pertinentes para o propósito deste trabalho.

O terceiro item aborda o princípio da mudança, suas origens filosóficas e suas consequências para a educação, especialmente as que tangem à centralidade do estudante em relação ao modelo pedagógico, e suas consequências para a sociedade em seus aspectos ético, político e moral.

O item quatro pretende expor os fundamentos de psicologia apropriados por Kilpatrick, que compreendem, especificamente, as leis de aprendizagem e o processo de formação da identidade pessoal, os quais compreendem principalmente o pensamento de Edward Lee Thorndike e George Herbert Mead.

A psicologia e filosofia deweyanas foram referenciadas por todo o trabalho, visto que constituem a principal fonte teórica de Kilpatrick.

Este trabalho também propõe uma leitura do pensamento de Kilpatrick sob o princípio pragmatista de ruptura das dicotomias mente-corpo e indivíduo-sociedade, princípio, esse, que, na obra Método de Projeto, de 1918, encontra-se circunscrito ao ambiente escolar e à didática e, posteriormente, em 1951, na obra Filosofia da Educação, radicaliza-se sob a forma de uma filosofia da educação.

A relação indivíduo-sociedade sob a ótica pragmatista manifesta-se na educação, por exemplo, na querela educacional do "ensino de matérias" e o "ensino de crianças", a qual, concebida segundo o conceito deweyano de experiência, tende a perder seu estatuto dicotômico. E é nesse sentido que este trabalho visa a averiguar até que ponto Kilpatrick seguiu na direção da superação da dicotomia "ensinar matérias" ou "ensinar crianças", de modo a argumentar em favor de uma educação que vise ao ensino de "o que pensar", "como pensar" e "como agir pensadamente".

As considerações finais, por sua vez, constituir-se-ão da retomada das questões acerca das concepções de democracia, de educação e de escola e de seu papel numa sociedade que se pretende democrática, mas, cujo futuro é incerto. Especificamente em relação à educação e à escola, serão retomados os argumentos que elucidam a ruptura com as dicotomias mente-corpo e indivíduo-sociedade. 


\section{METODOLOGIA DESTA PESQUISA}

Diante da importância e do esforço em compreender o autor, este trabalho visa a expor o pensamento de Kilpatrick tomando como referência as obras que mais representam seu posicionamento intelectual em relação especificamente à educação.

Embora o que se almeje é proporcionar ao leitor a percepção das permanências e rupturas que marcaram seu pensamento, o conteúdo de suas obras não será explanado estritamente segundo sua cronologia e obra por obra. A exposição se dará de forma temática, o que de modo algum sugere uma leitura fragmentária do pensamento do autor ora tratado. E embora certos posicionamentos teóricos fossem mantidos por Kilpatrick ao longo da vida, houve, de fato, aqueles que em certo momento foram, pelo autor, reconsiderados: tais reconsiderações serão explicitadas neste texto.

Cada tema é interdependente dos demais e visa a esclarecer sob a perspectiva do autor em estudo, as seguintes questões mais centrais: a) o que é democracia? b) o que é educação? e c) qual o papel da educação e da escola numa sociedade que se pretende democrática e em permanente transformação?

Essas questões serão explanadas por meio do desenvolvimento de dois eixos temáticos presentes na filosofia da educação de Kilpatrick, a saber, o ensino e a psicologia; sendo que ambos respondem a um princípio central, o da mudança.

Como mencionado, uma das correntes escolanovistas presentes na literatura educacional brasileira que dialogam diretamente com Kilpatrick são as que, por exemplo, coadunam com a interpretação feita por Lourenço Filho em Introdução ao estudo da escola nova a realizada por Anísio Teixeira em Pequena Introdução à Filosofia da Educação.

Evidentemente, há outros autores brasileiros que se debruçaram sobre o pensamento de Kilpatrick, por exemplo Leite (2005), em A noção de projeto na educação: o método de projeto de William Heard Kilpatrick, quando buscou explicitar a noção de projeto em Kilpatrick e sua relação com a modernidade. Leite (2005) parte da hipótese de que o conceito de projeto presente em Kilpatrick evidencia uma visão dicotômica por parte do autor acerca da relação indivíduosociedade, visto que, segundo a autora, Kilpatrick concebe a formação do indivíduo como um processo independente das condições sociais favoráveis para sua concretização.

Bin (2012), preocupada com a lacuna de pesquisas em língua portuguesa que se dediquem à abordagem da pedagogia de Kilpatrick, escreveu Concepções de Conhecimento $e$ Currículo em W. Kilpatrick e implicações do método de projetos, uma obra em que há, ao mesmo tempo, um cotejamento entre Kilpatrick e Fernando Hernández sob o ponto de vista 
didático e uma abordagem multifacetada sobre o pensamento de Kilpatrick e suas contribuições para a atualidade.

Este trabalho, por sua vez, propõe uma leitura pragmatista da obra de William Heard Kilpatrick. A metodologia é composta de dois elementos. O primeiro, a leitura rigorosa das obras de Kilpatrick e, então, sua exposição. O segundo, a exposição da vida pessoal e acadêmica do autor.

Como passo metodológico, a descrição da vida pessoal e acadêmica de Kilpatrick justifica-se em função de dois propósitos.

O primeiro consiste em manter em seu aspecto histórico a integridade da obra de Kilpatrick por meio da contextualização do autor enquanto sujeito histórico-cultural. Essa contextualização fundamenta-se no conceito deweyano de educação, a partir do qual supõe-se que um sujeito é determinado - e não pré-determinado, segundo Kilpatrick - por sua (re)ação pensada em relação ao ambiente.

Segundo essa concepção de educação, Kilpatrick agira como agira e pensara o que pensara em função de incontáveis feixes de experiências pessoais reconstruídas e, consequentemente, ressignificadas a partir do contato consciente com situações do ambiente. Como consequência desse processo de reconstrução do antigo por meio da incorporação do novo o pensamento do autor torna-se produto de um processo não apenas onto, mas também sociogênico, onde a cultura é fator necessário para que haja o próprio pensamento.

A educação vista sob esse prisma, como processo - ou, mais propriamente, como experiência reflexiva, segundo Dewey -, é inerente à vida consciente humana, inclusive os processos de aprendizagem que, para o educando, são menos evidentes, chamados por Thorndike e por Kilpatrick de aprendizagens concomitantes. Desse modo, o caráter do sujeito é o resultado do entrecruzamento de todas as suas experiências educativas.

O segundo objetivo da contextualização histórica do sujeito da pesquisa é complementar ao primeiro e busca, em relação ao leitor, a superação das dicotomias mente-corpo, pensamentoação e texto-contexto. Nesse sentido, e considerando os limites da competência científica deste autor, o presente trabalho intenta proporcionar ao leitor uma experiência dewey-kilpatrickiana de leitura, oferecendo informações tanto acerca do autor em questão quanto do produto de sua vivência como educador e intelectual, de modo a cuidar para que o leitor, enfim, tenha uma percepção histórica e humana dos conceitos aqui expostos. Desse modo e em suma, propõe-se um trabalho pragmatista em forma e conteúdo. 


\subsection{VIDA E OBRA DE KILPATRICK}

William Heard Kilpatrick nasceu em White Plains durante o período conhecido como Reconstrução, ou, dito no modo sulista estadunidense "a sombra da Guerra de Secessão". Na época, White Plains era um vilarejo agrícola localizado em Greene County, porção centro-norte da Georgia (BEINEKE, 1998, p.01). Embora, segundo censo realizado em 1890, Grene County mostrasse uma população negra de 11.719 de um total de 17.051, ainda assim permanecia uma sociedade culturalmente conservadora, eurocêntrica e escravocrata (ibidem, p.02).

Durante os últimos trinta anos do século XIX, por razões políticas e sociais que envolviam principalmente o racismo, o sul dos Estados Unidos fora marcado por forte onda de violência. Embora White Plains não houvesse sido palco especificamente desse tipo de violência, do ponto de vista econômico e social o vilarejo encontrava-se em meio a uma permanente recessão, conhecida como Pânico de 1873, e a uma crise econômica provocada por altas tarifas do algodão e pela eliminação do trabalho escravo.

Além de um forte sentimento regionalista por parte do sul, tão ou mais forte era o sentimento religioso, que chegou a ser incorporado à rotina das escolas de modo que cada dia de aula se iniciava com uma oração.

Kilpatrick teve uma educação marcada pelos princípios e doutrina protestantes, o que possivelmente explicaria referências a episódios bíblicos feitas posteriormente em seus trabalhos.

O avô de Kilpatrick, James Hall Kilpatrick, foi um ministro batista e sua esposa, Harriet Eliza Jones, também fazia parte da vida religiosa.

James Hines Kilpatrick - pai de Kilpatrick - nascera em 1833, e, quando mais velho, graduou-se na Universidade Mercer em Macon, Georgia, e ingressou na vida ministerial da Igreja Batista. Em White Plains, exerceu tanto o magistério quanto funções executivas na administração do vilarejo, inclusive a de prefeito. (ibidem, p.06).

Sua relação afetiva com Kilpatrick era distante, embora esse o admirasse pela inteligência. Contudo, mesmo que o pai de Kilpatrick - o Dr. Kilpatrick, em virtude de um título honorário da Mercer - tornar-se-ia um dos mais influentes batistas na Georgia, seria com sua mãe, Edna Perrin Heard - nascida em Augusta, Georgia, 1843 - que Kilpatrick encontraria oportunidade de estabelecer um maior vínculo afetivo.

Kilpatrick não raras vezes reafirmou a influência que sua mãe exerceu em sua vida, inclusive enquanto professor, devido à sua gentileza, bondade, sensibilidade e atitude de encorajamento. Em 1925, logo após sua morte, Kilpatrick escreveria na dedicatória de 
Fundamentos do Método: “À memória de minha mãe, primeira e maior de meus professores." (BEINEKE, 1998, p.07-09, tradução nossa).

Edna estudou na Escola Preparatória do Colégio Presbiteriano para Mulheres Jovens, depois em Greensboro e Covinston, Georgia, e finalmente em White Plains, local onde lecionou como tutora. Edna também lecionou em um orfanato, em Augusta, Georgia; e quando ainda era estudante em White Plains, conheceu o pai de Kilpatrick (ibidem, p.08).

\subsubsection{William Heard Kilpatrick}

Kilpatrick nasceu em 20 de novembro de 1871, no mesmo vilarejo em que onze meses antes seus pais haviam se casado e construído uma casa. Era o filho mais velho do casal, já que após seu nascimento também viriam Helen, Sarah e Howard.

Após a morte da esposa, seu pai se casaria novamente e Kilpatrick teria outros irmãos, entre os quais duas meias-irmãs que viriam a morrer em 1896 de febre tifoide. Esse evento levou Kilpatrick, ainda adolescente, engajar-se ainda mais no protestantismo; engajamento, esse, que perduraria até sua entrada no colégio, dois anos depois (BEINEKE, 1998, p.10-11).

O colégio era parte integrante de um sistema educacional para estudantes de seis a dezoito anos, na Georgia. Segundo Kilpatrick, o ensino era metodologicamente convencional, tradicional e muitas vezes sexista, quando durante a chamada "as meninas respondiam 'presente' e se sentavam longe do professor, enquanto os meninos respondiam 'aqui' e se sentavam à frente." (ibidem, p.12, tradução nossa).

No final do século XIX, muitas escolas já contavam com um tradicional curso preparatório para o ingresso na universidade. Aos doze anos, Kilpatrick iniciou seus estudos de latim e grego e depois seguiu com o estudo de álgebra, geometria, trigonometria, inglês e retórica. E, em 1888, aos dezessete anos, ingressou na Universidade Mercer.

Uma considerável desenvoltura intelectual enquanto estudante universitário, principalmente em matemática e física, proporcionou a Kilpatrick o vislumbre de uma possível carreira como engenheiro. Porém, Kilpatrick passaria por um grande autoquestionamento que resultaria em uma crise pessoal-existencial. Conforme relatou o próprio, "esse impacto significaria uma completa rejeição de minha educação religiosa e filosófica.” (TENENBAUM, 1951, p.13-14). Essa crise pessoal-existencial levou Kilpatrick a abandonar sua crença na imortalidade da alma. E isso se deu após a leitura de $A$ descendência do homem e a seleção em relação ao sexo, de Charles Darwin. 
Apesar de o darwinismo haver abalado suas crenças, inclusive crenças religiosas, em relato a Tenenbaum (ibidem, tradução nossa), Kilpatrick afirma:

No momento, [após o início da crise,] eu não sei de nada que possa substituir o lugar [antes ocupado pela religião]. Foi, antes, uma rejeição do que eu pensava anteriormente. Mas, ao contrário do que muitas pessoas profetizaram acerca dessa questão, eu não mudei em nada minha visão moral de mundo. Até o momento, não tenho qualquer teologia, porém minha vida social e moral continuou exatamente do mesmo modo.

Desse modo, apesar de Kilpatrick não indicar mudanças em seu paradigma moral pessoal, o objeto de sua crise pessoal-existencial se colocaria em alguma medida em choque com sua fé religiosa.

\subsubsection{Origens da obra Método de Projeto}

Ao final de sua trajetória na Mercer, em 1891, surgiram para Kilpatrick algumas possibilidades de permanecer inserido na vida acadêmica. A primeira foi a de retornar na mesma universidade como assistente de professor nas áreas de matemática e física; a segunda, de estudar engenharia civil no Instituto Militar de Virginia; e a terceira, de ingressar na Universidade Johns Hopkins, em Baltimore. Kilpatrick optou pela última, o que para ele significou ampliação de repertório teórico e também de sua capacidade crítica em vários aspectos, como teologia, política ou mesmo didática (BEINEKE, 1998, p.18-19).

No verão de 1892, viajou para o sudoeste da Georgia com a intenção de assumir uma vaga de professor em uma escola na cidade de Blakely. Mais tarde, John Wade, um colega de sala na Mercer, assumiu o posto de diretor nessa mesma escola e, então, convidou Kilpatrick para dividir o cargo com ele. Wade passou a ser o responsável pela disciplina dos estudantes, enquanto Kilpatrick, a responsabilizar-se pela organização curricular.

Ao mesmo tempo em que trabalhava como diretor em Blakely, Kilpatrick também passou a dar aulas em Rock College, uma escola normal em Athens, norte da Georgia. Até então, sua visão de educação restringia-se a, como ele mesmo disse, "passar lições de um livro texto e então cobrá-las." (ibidem, p.21, tradução nossa).

Entretanto, sua visão acerca do processo educacional mudou após ouvir de Otis Ashmore, um colega professor, o relato de que, um dia, Ashmore havia deixado, por um breve período, os estudantes sozinhos na sala de aula realizando atividades, sem supervisão. Quando um visitante à procura de Ashmore entrou na sala, encontrou seus alunos totalmente envolvidos na atividade, sem que houvesse qualquer necessidade de coação. 
Para Kilpatrick, esse relato pareceu lançar luz ao fato de que seria realmente possível aos estudantes realizar suas tarefas por meio de uma motivação intrínseca e sem necessidade de serem vigiados. Essa situação ocorreu em $1892 \mathrm{e}$ foi o primeiro passo em direção à obra Método de Projeto, publicada em 1918.

\subsubsection{Interesse pela educação como objeto de investigação}

Para alguém que começa a questionar uma pedagogia centrada no professor e, então, predispõe-se a adotar um paradigma pedagógico radicalmente diferente, centrado no estudante, é necessário um aprofundamento, por exemplo, nos fundamentos de cada uma dessas perspectivas, ou ainda, uma reflexão que traga à baila a discussão sobre o sentido do ensinar e do aprender. Foi a partir dessa lógica que Kilpatrick passou, por conta própria, a investigar mais a fundo a literatura educacional. Em outras palavras, "partiu para os clássicos": inicialmente, Frederick Froebel e Johann Pestalozzi (BEINEKE, 1998, p.22).

Enquanto desempenhava sua função de diretor, Kilpatrick concordou em lecionar matemática, grego e latim para o oitavo, o nono e o décimo níveis, e não tardou em colocar em prática os ideais de Pestalozzi em sua turma. Desse modo, seu conhecimento teórico e sua experiência como educador continuaram a se expandir.

$\mathrm{Na}$ primavera que se seguiu, Kilpatrick viajou à Albany, Georgia, para ouvir Colonel Francis Parker, considerado por muitos o pai da educação progressiva e conhecido principalmente por meio de um livro escrito por Lelia E. Partrige, chamado The Quincy Method. Esse livro relata as experiências de Parker em Quincy, Massachussets (ibidem, p.23).

Kilpatrick leu essa obra e logo buscou implementar práticas mais progressivas na escola, como, por exemplo, substituir os boletins mensais por relatórios de aprendizagem, e também passou a buscar novos métodos de ensino de matemática (ibidem, p.23).

Ao final de três anos como professor e diretor em Blakely, Kilpatrick havia economizado dinheiro suficiente para retornar a Johns Hopkins e seguir com seu Ph.D. em matemática. Porém, por motivos pessoais, em vez de matemática, matriculou-se em grego e filosofia (ibidem, p.24-25).

Após deixar Hopkins, Kilpatrick entrou em contato com seu antigo colega de Rock College, Otis Ashmore, e, em virtude de uma proposta de cargo de diretor em uma das escolas de Ashmore, foi para Savannah. 
Em Savannah, continuou sua progressiva mudança de atitude pedagógica sob a mesma ideia de que a motivação intrínseca é o ponto chave para a aprendizagem, além do reconhecimento do indivíduo pelos outros (BEINEKE, 1998, p.26-27).

Além de sua atuação como diretor, Kilpatrick foi convidado por Dr. Pickney Daniel Pollack, presidente da Universidade Mercer, a assumir a cadeira de matemática e astronomia. Kilpatrick aceitou o convite e não demorou a conhecer e a estabelecer uma amizade duradoura com o professor de história da instituição, J. R. Moseley, de cuja revista Magazine Club Kilpatrick seria, futuramente, o coordenador.

Durante uma viagem, Kilpatrick conheceu Olin Wimberly, um advogado que lecionava na escola de direito da Mercer. Em janeiro de 1898, por meio de Wimberly, Kilpatrick veio a conhecer Marie Bemem Guyton, prima de Wimberly, com quem estabeleceu o que no começo fora um breve relacionamento e, em menos de um ano, culminaria em união matrimonial. Em pouco mais de dois anos, nasceria a filha do casal, Margaret Louise (ibidem, p.30).

Seu trabalho na Mercer na área de matemática levou-o a duvidar da efetividade de uma prática pedagógica que, mesmo em se tratando de matemática, tendesse a se resumir em simples treinamento. Kilpatrick encontrava muita dificuldade em manter o interesse dos alunos, ao mesmo tempo em que seu próprio interesse também começava a decair.

Nesses momentos, perguntava-se se a matemática tradicional não poderia ser ensinada de acordo não somente com uma nova didática, mas também de acordo com uma filosofia da educação mais efetiva. Foi a partir de então que Kilpatrick passou a diversificar seu objeto de estudo. Inicialmente, passou a ler mais a fundo sobre educação e administração, e, mais tarde, sobre ética e psicologia educacional (ibidem, p.31).

De fato, Mercer não oferecia qualquer curso que tivesse a educação como disciplina formal. Porém, além de coordenar a filosófica Magazine Club, a revista que fora de Moseley, Kilpatrick durante um bom tempo vinha organizando reuniões de um grupo de discussão sobre problemas educacionais, dentro do qual fora realizada, por exemplo, a leitura de Herbert Spencer e também do livro Diálogos com professores, de William James (ibidem, p.31).

No verão de 1898, Kilpatrick viajou para o norte dos Estados Unidos para fazer dois cursos na Universidade de Chicago, um em matemática e o outro em educação. No primeiro, Kilpatrick ficou desencorajado devido ao alto nível de dificuldade do problema matemático apresentado aos cursistas. Quanto ao segundo, Kilpatrick não se sentiu mobilizado pelas questões apresentadas pelo palestrante John Dewey.

Dois anos depois, Kilpatrick viajou ao Estado de New York para mais dois cursos, desta vez na Universidade Cornell, em Ithaca. Diferentemente da outra vez em que o curso de 
matemática fora muito exigente, Kilpatrick, dessa vez, decepcionou-se pelo fato de ser pouco instigante. Porém, o curso de educação ministrado por Charles De Garmo a partir do texto Interesse relacionado à vontade (mais tarde intitulado Interesse e esforço), de Dewey, constituiu-se como um divisor de águas em sua trajetória intelectual, tal como dissera a Tenenbaum (1951, p.37, tradução nossa):

Este livro abriu um mundo completamente novo para mim, como nenhum livro jamais o fizera. [...] O ponto de partida em toda educação - o cerne do processo educativo - é o interesse individual; mais que isso, o melhor e mais rico tipo de educação começa com o próprio impulso do interesse.

Em 1902, Kilpatrick e outros cento e sessenta e dois georgianos, fomentados pela Rockefeller Fundation, integraram a Escola de Verão do Sul, em Knoxville, Tennessee. Essa iniciativa o incentivou ainda mais a manter a educação como objeto de estudo e, agora, de pesquisa. Ao mesmo tempo em que continuou fascinado pelos trabalhos de William James, gradativamente foi desinteressando-se pela matemática (BEINEKE, 1998, p.35).

A partir de 1903, Kilpatrick assumiu a presidência da Universidade Mercer, inclusive com o intuito de encontrar uma solução para a forte crise financeira pela qual passava a instituição. Durante esse período, os Kilpatricks tiveram outra filha, que, infelizmente, morreu em uma semana. Isso ocorreu ao mesmo tempo em que Marie começou a apresentar os primeiros sintomas de tuberculose (ibidem, p.36).

Em 1904, uma palestra intitulada O progresso educacional do século marcou o início da identidade de Kilpatrick como educador progressista. A ênfase da palestra estava na ideia de que "a educação do futuro não teria como foco o treino de memorização de informações. Mais que isso, teria como foco as sensações, sentimentos e emoções, que são questões relacionadas à vida." (ibidem, p.38, tradução nossa).

Os anos que se seguiram como presidente da Mercer foram marcados por problemas que envolviam sua posição como administrador e suas concepções filosóficas e teológicas. Acusado de "herege", Kilpatrick fora fortemente perseguido pela comunidade acadêmica. Sua situação constrangedora, juntamente com a saúde precária de sua esposa, fez com que, em 1906, os Kilpatricks se mudassem para Columbus, Georgia, uma cidade rural onde Kilpatrick assumiria a função de diretor e professor de matemática em uma escola.

Em 29 de Maio de 1907 sua esposa Marie faleceu. Kilpatrick tinha trinta e cinco anos e sua filha, Margaret, seis. 


\subsubsection{John Dewey e a Universidade Columbia}

Após a morte da esposa, enquanto via-se forçado a deixar sua filha com seus pais e irmã em White Plains, Kilpatrick planejava cursar seu doutorado na principal instituição de educação do país, possivelmente do mundo, o Teachers College da Universidade Columbia, na cidade de New York (BEINEKE, 1998, p.51).

Com as questões pessoais resolvidas dentro do possível Kilpatrick encontrou-se com Dewey em setembro de 1907 para elaborar o planejamento de seus estudos.

Durante o período em que esteve no Teachers College, além de Dewey, Kilpatrick foi fortemente influenciado por Edward Lee Thorndike, aluno de William James, professor, pesquisador e um pioneiro na clássica fórmula de aprendizagem baseada no esquema estímuloresposta $(S \rightarrow R)$. Do ponto de vista intelectual, Kilpatrick considerava Thorndike tão brilhante quanto Dewey.

Dewey havia chegado à Columbia em 1904, depois de dez anos na Universidade de Chicago. Embora oficialmente associado ao departamento de Filosofia da Universidade Columbia, Dewey lecionou em vários cursos no Teachers College e também participou de várias comissões no doutorado.

Em 1908, Kilpatrick retornou abruptamente a White Plains por conta do agravamento do estado de saúde de seu pai, que, em março do mesmo ano, viria a falecer.

Depois da morte de seu pai, Kilpatrick foi para a Universidade da Georgia, em Athens, para ensinar psicologia educacional, história da educação e matemática.

Após o retorno à Universidade Columbia, Kilpatrick continuou sua busca por um tema de pesquisa, até se interessar por história da educação, particularmente sobre as primeiras escolas holandesas surgidas na colônia, tema a partir do qual elaborou sua tese (ibidem, p.56).

No mesmo ano, Kilpatrick casou-se com Rita.

$\mathrm{Na}$ arena profissional, Dewey havia modificado profundamente a visão de mundo e de educação de Kilpatrick.

Kilpatrick, além de reconhecer a dimensão dos conceitos de interesse e esforço presentes na obra de Dewey, buscou generalizar a nova filosofia - o experimentalismo - para todas as situações da vida, pois, consonante ao que pensa Dewey, Kilpatrick afirma que

nós deveríamos usar os métodos da ciência tanto quanto pudermos em todas as situações da vida, assim como fundamentar neles nossa filosofia. [...] Usando a inteligência, o homem deveria estar constantemente empenhandose por tornar a vida melhor (TENENBAUM, 1951, p.78-79, tradução nossa).

Segundo essa filosofia, do ponto de vista ético, pode-se dizer que 
a inteligência passou a ser o fim e o meio da vida. No contexto da filosofia pragmática, razão indutiva e seus resultados práticos passam a ser o processo pelo qual alguém busca a boa vida. [...] Uma coisa é boa ou má na medida em que ela torna a vida [também] boa ou má para todos os envolvidos (ibidem, p.79, tradução nossa).

Dessa maneira, Kilpatrick percebeu, a partir do contato com Dewey, que é preciso aprender não apenas o que pensar, mas também como pensar. E esse é, para Kilpatrick, o significado da inteligência tomada como propósito na educação.

\subsubsection{Kilpatrick como intelectual}

Durante o ano letivo de 1910, Kilpatrick ensinou história da educação no Teachers College da Universidade Columbia. Em virtude do estado de saúde de Mac Vannel, professor de filosofia da instituição, em novembro do mesmo ano também assumiu as aulas de filosofia da educação.

Em janeiro de 1911, defendeu sua tese. Duas semanas após a defesa, recebeu o convite para se tornar professor associado da instituição, o qual aceitou, embora estivesse conjecturando também um cargo em Knoxville, Tennessee.

Em junho do mesmo ano, viajou à Europa para conhecer de perto o trabalho de Maria Montessori, educadora e física italiana. Um mês antes de sua ida, Thorndike manifestara algumas críticas contra o método montessoriano, às quais Kilpatrick somou as suas próprias. Em 1914, Kilpatrick publicou O sistema Montessori examinado, com suas observações e críticas acerca dessa pedagogia (BEINEKE, 1998, p.72).

Nos meses que se seguiram, Kilpatrick continuou a ganhar espaço tanto nas salas de aula quanto nos auditórios, e havia alguns motivos para tal.

Em primeiro lugar, ao mesmo tempo em que estava apto a comunicar e popularizar as ideias de Dewey, Kilpatrick também tecia críticas consistentes a vários pensadores da educação: Assim como fizera, por exemplo, em relação à pedagogia montessoriana, Kilpatrick publicou, em 1916, Princípios do Jardim de Infância de Froebel criticamente examinados.

E em segundo lugar, Kilpatrick havia conquistado um grande respeito da comunidade acadêmica e de educadores em geral (ibidem, p.77).

Por volta de 1917, já havia também se estabelecido como palestrante, cujos temas correntes eram Interesse e educação, Educação como socialização, O método de projetos, Princípios subjacentes ao jardim de infância e à educação primária, Educação como atividade e Democracia e educação. 
Em 1915, fora promovido a professor associado, desta vez, em filosofia da educação. Evidentemente, ao mesmo tempo em que tinha o objetivo tornar-se professor integral - o que viria de fato a ocorrer em 1918 -, tinha como preocupação superar sua situação de "discípulo" ou “expositor" da filosofia de Dewey. Então, no final do ano de 1918, Kilpatrick publicou no jornal Teachers College Record um artigo intitulado Método de Projeto: a utilização do ato intencional no processo educativo.

Na década seguinte, Kilpatrick publicou três livros, diferentes em foco, conteúdo e estilo, mas que, conjuntamente, fazem a conexão lógica entre as ideias de Método de Projeto e seu pensamento posterior. Em 1923, publicou Livro referência em filosofia da educação; em 1925, Fundamentos do Método: diálogos informais sobre ensino; e em 1926, Educação para uma Civilização em Mudança (BEINEKE, 1998, p.134).

Em Livro referência em filosofia da educação, Kilpatrick organizou e agrupou em forma de sumário: citações, epigramas, excertos de artigos e anotações compiladas de aula, cujo conteúdo trata de democracia, progresso, currículo, pensamento, educação moral, natureza e sociedade, o conceito de experiência, entre outros temas (ibidem, p.134). Um dos motivos pelos quais Kilpatrick concebeu e organizou esse livro foi o desejo de prover seus estudantes e outros leitores interessados por filosofia de um conteúdo abrangente, organizado e que pudesse contribuir de alguma forma para sua formação.

Em Fundamentos do Método: diálogos informais sobre ensino, Kilpatrick aborda temas concernentes às discussões que compunham um de seus maiores cursos, Fundamentos do Método. Em estilo diverso do adotado em outras publicações, o livro é composto pelo diálogo entre dois, às vezes três, estudantes matriculados em um curso similar ao próprio curso de Kilpatrick. O livro trata de assuntos concernentes ao curso, como a necessidade de bases científicas para o ensino; a aprendizagem sob regime de coerção; o desenvolvimento de atitudes, aspectos emocionais e sua relação com a construção do caráter; e aprendizagem primária e aprendizagem concomitante.

Além dessa temática, o livro remonta ao ato intencional e a mais alguns tópicos desenvolvidos em Método de Projeto, e a alguns elementos de Como pensamos, de Dewey, como os estágios da resolução de problemas (ibidem, p.139).

Em 1926, Kilpatrick publica Educação para uma Civilização em Mudança, uma compilação de três palestras dadas na Universidade Rutgers, no mesmo ano. O livro faz um elo entre o pensamento do autor em Método de Projeto e sua mudança de perspectiva no começo da década de 1930, que significaria, entre outras coisas, reconsiderar em certa medida a 
centralidade da criança dentro do currículo em função da necessidade de atender certas demandas decorrentes das crises econômica e social do país.

Na década de 1930, os contextos nacional e internacional exigiram uma resposta formal dos líderes governamentais e também dos educadores, a qual viria em setembro de 1932 com a publicação de Educação e crise social: um programa proposto. Ao manifestar sua preocupação com a situação social e econômica do país, Kilpatrick, nessa obra, dá ênfase à necessidade de reformas educacionais cujo cerne estaria tanto no currículo quanto na formação dos educadores (BEINEKE, p.203-204).

Mas, anteriormente, em Fevereiro de 1932, em coautoria com John Dewey, John R. Childs e outros, Kilpatrick publicara A fronteira educacional, cujo principal objetivo era o de oferecer um livro sobre educação que fosse uma resposta, do ponto de vista filosófico, à situação pela qual passava a nação, e então discutir qual seria o papel da educação naquele contexto. Kilpatrick contribuiu com dois capítulos, um sobre educação de adultos e outro sobre formação de educadores (ibidem, p.207).

Em julho de 1936, a partir de uma série de artigos publicados anteriormente, Kilpatrick publicou Reformulando o Currículo. De certo modo, esta obra requer atenção especial, pois ao mesmo tempo em que Kilpatrick mantém consistente sua filosofia da educação, evidencia tanto uma reconsideração sobre o papel do behaviorismo como psicologia educacional quanto sua apropriação da psicologia de George Herbert Mead.

Quanto a essa reconsideração, pode-se dizer que Kilpatrick reconhece a contribuição de Thorndike para a educação, tal como em Método de Projeto e Fundamentos do Método. No entanto, Kilpatrick pensava que, em primeiro lugar, a psicologia não deveria permanecer apenas voltada a si mesma, sem estabelecer preocupações com o contexto social. E, em segundo lugar, Kilpatrick também via a necessidade de uma perspectiva de psicologia com uma natureza mais criativa, que fosse mais abrangente e que envolvesse a busca pessoal e consciente de propósitos e que tivesse como objetivo a auto direção (BEINEKE, 1998, p.232).

Por essa razão, Kilpatrick criticou o rumo tomado pelos behavioristas, pois, segundo o autor, o behaviorismo, enquanto ciência falhou por

reduzir os traços superiores ou distintamente humanos a algo inferior, principalmente a processos psicológicos ou físicos. [...] O pensamento do homem, sua responsabilidade moral e sua criatividade estética não poderiam ser reduzidos meramente a processos animalescos ou físicos sem romper essencialmente com o ser em si (KILPATRICK, 1941, p.85, tradução nossa). 
Para Kilpatrick, esse reducionismo significaria uma compreensão do comportamento humano de modo estritamente mecânico. A crítica de Kilpatrick ao behaviorismo será abordada com maior profundidade no item quatro deste trabalho.

Por ora, é suficiente afirmar que, contrapondo-se ao reducionismo levantado por Kilpatrick, em Reformulando o Currículo, o autor enfatizaria a centralidade dos sentimentos e emoções na aprendizagem, pois ambos também são responsáveis pelo esforço empregado pelo estudante na busca de soluções para os problemas. A aprendizagem é retomada por Kilpatrick como um processo em que há a reconstrução e reorganização da experiência por meio do envolvimento integral da pessoa - uma visão deweyana de educação -, o que, de fato, fora desconsiderado pelos behavioristas (BEINEKE, 1998, p.232).

Uma maior convicção dessas ideias viria em 1941, com a publicação de Identidade Pessoal e Civilização: um estudo do processo self-other, cujo ponto de partida é a ideia de que o cerne do processo educativo, que compreende também a formação da identidade pessoal, é o processo self-other em meio a um ambiente social (ibidem, p.304).

Segundo Beineke (1998, p.304, tradução nossa, grifo do autor),

a tese de Kilpatrick in Identidade Pessoal e Civilização é a de que a identidade humana, em todos os sentidos, é inerentemente um produto social. Ser-se humano, como disse, é desenvolver-se por meio de um processo de maturação social em estágios e níveis, e isso poderia ocorrer somente em um ambiente social e em um contexto cultural particular. Este é o amálgama das experiências primárias e vicárias das quais emerge o conceito de self-other. Este conceito não representa necessária ou absolutamente o autoconceito da criança. [...] O resultado ideal do conceito de self-other ocorre quando as crianças veem elas mesmas como outras, o que permite o uso crítico dessa experiência em suas próprias vidas.

Kilpatrick afirma no Prefácio de Identidade Pessoal e Civilização que o objetivo do livro é

mostrar a natureza essencial do self-other na identidade pessoal e mostrar como a civilização, que cresceu a partir de identidades pessoais tão diferentes, deve continuar a crescer para se desenvolver e expressar ainda mais plenamente essas identidades (KILPATRICK, 1941, tradução nossa).

Conforme exposto em Método de Projeto, Kilpatrick em Identidade Pessoal e

Civilização reafirmou o principal aspecto ético-moral de sua metodologia, a saber:

é preciso que haja abundância de oportunidades para os jovens para que, sempre sob orientação correta, tomem decisões com o objetivo de formar um caráter convicto, com pensamento racional e hábitos de ação que testam a própria razão. A orientação [de alguém mais experiente] pode assistir, mas não compelir; e o racional não deve sobrepor-se ao emocional (BEINEKE, 1998, p.308). 
Entre 1939 e 1943, Kilpatrick foi diretor editorial de A fronteira social, um jornal de conteúdo político e educacional surgido após a Grande Depressão e publicado no Teachers College da Universidade Columbia. Muitos de seus idealizadores defendiam os ideais do Reconstrucionismo Social, um movimento que buscou solucionar os problemas relacionados à desigualdade socioeconômica por meio da reforma cultural (HILL, 2006, p.96-97). Contribuíram com o jornal: John Dewey, Sidney Hook, Leon Trotsky, John Childs, Kilpatrick entre outros (BEINEKE, 1998, p.213-214).

Em 1951, como resultado do trabalho de cinco anos, Kilpatrick publica sua obra magna Filosofia da Educação, na qual desenvolve de modo coeso e minucioso vários temas, ideiaschave e conceitos dos quais lançou mão ao longo de sua trajetória como educador e intelectual.

Em 14 de Fevereiro de 1965, Kilpatrick falece aos 93 anos. 


\section{A MUDANÇA COMO PRINCÍPIO E A EDUCAÇÃO}

Os mecanismos descritos por Peirce que compõem sua teoria da crença e da dúvida são tributários do pensamento de Darwin, expresso em A origem das espécies, o qual considera a inquirição não mais como uma característica "de divindade" para separar o homem da besta, mas, antes, um mecanismo de adaptação por meio do qual os organismos reagem às mudanças concretas do seu ambiente no intuito de reaver seu equilíbrio homeostático (WAAL, 2007, p.32). Nesse sentido, para Peirce, o exercício racional que visa a superar um estado de dúvida para alcançar um estado de crença encontra-se circunscrito num universo que compreende natureza e cultura concebidos de modo não-dicotômico.

Este item visa à elucidação do significado da adaptação biológica para a educação, quer dizer, de que modo esse princípio, inicialmente circunscrito à Biologia, acaba por repercutir na filosofia e, então, na educação.

\subsection{PRAGMATISMO E HERANÇA DARWINIANA}

O pragmatismo surgiu nos primeiros anos da década de 1870 do encontro regular de alguns jovens intelectuais de Cambridge, Estados Unidos, cuja intenção era discutir filosofia. Esse grupo, chamado "Clube Metafísico", incluía, entre outros, William James, Charles Sanders Peirce, Oliver Wendell Homes Jr. e Nicholas Saint John Green (ibidem, p.17).

As discussões que ocorriam no grupo, segundo Waal (2007, p.17), giravam, frequentemente, em torno do conceito de crença, quando, a partir de um certo momento, deuse atenção especial a uma definição proposta pelo pensador escocês Alexander Bain segundo a qual crença é aquilo com base em que um homem está preparado para agir. Essa definição será, para Peirce, objeto de reflexão e culminará naquilo que o autor denominou estado de crença, cujo oposto é o estado de dúvida.

Esses dois estados carregam distinções importantes. O estado de crença se traduz por um estado intelectual de fixidez; e seu oposto evoca um estado insatisfatório, desconfortável e do qual a pessoa luta para se libertar. E, embora ambos conduzam à ação, cada um o faz de modo diferente.

O estado de dúvida, para Peirce, comporta-se como um estímulo direto para a inquirição, o qual cessará tão logo a dúvida tenha sido sanada. O estado de crença, por outro lado, 
quando a ocasião surgir". Isso quer dizer, para Peirce, que a crença é o estabelecimento de um certo hábito que determinará como agiremos quando apropriadamente estimulados. [...] Já que para Peirce o próprio motivo da inquirição é nos livrarmos do desconforto da dúvida, o objetivo último de toda inquirição nada mais é do que reaver um estado de crença (PEIRCE, 1998, p.114 apud WAAL, 2007, p.31-32, grifo do autor).

O conceito peirceano de crença estará presente de forma subjacente em A Natureza Humana e a Conduta: uma introdução à psicologia social, de John Dewey e no pensamento de Kilpatrick, por exemplo, na obra Identidade Pessoal e Civilização, explanada com maior profundidade no item quatro deste trabalho.

De modo análogo a Peirce, Dewey concebe hábito como uma disposição interna da pessoa que se caracteriza por demonstrar um certo nível de inercialidade, porém, não se confunde com um mero processo de repetição, já que o processo de sua formação "envolve o início de uma especialização intelectual” (DEWEY, 1956, p.139).

O hábito, na verdade, possui um componente teleológico que o transforma em ferramenta necessária para que o indivíduo possa modificar o ambiente. Diz, Dewey:

podemos considerar os hábitos como meios, como ferramentas em uma caixa à espera do momento em que serão chamados e usados por uma resolução consciente. Mas eles são alguma coisa mais do que isso. Eles são meios ativos, meios que se projetam, modos de atividade enérgica e dominante. [...] [Os hábitos] integram uma organização de entes que independentemente levam a efeito resultados definidos (DEWEY, 1956, p.32).

Para Dewey, a efetivação na pessoa de determinados hábitos se manterá ativa enquanto não houver divergências entre os resultados intelectivamente projetados e os até então efetivados, ou seja, enquanto houver consonância entre seus fins em vista e as consequências efetivadas no ambiente, a conduta não sofrerá mudanças. Percebe-se, então, que o mesmo conceito de adaptação biológica presente na filosofia de Peirce está, conforme Waal (2007, p.32) presente na psicologia social de Dewey, psicologia, essa, que será apropriada e expressa por Kilpatrick em A Filosofia da Educação de Dewey (1953, p.78).

\subsubsection{Kilpatrick e conceito deweyano de experiência}

O pragmatismo clássico busca a superação da dicotomia corpo-mente, pensamentoação. Diante desse objetivo geral, cada filósofo pragmatista enveredou-se por questões mais específicas, e cada qual, a seu modo, construiu um pensamento a partir de um mesmo conceito- 
chave: experiência. Kilpatrick segue na mesma linha ao propor uma filosofia da educação baseada na experiência, o que o torna integrante e intérprete desse pensamento.

Experiência, na obra de Kilpatrick, assume outras terminologias em razão do fenômeno ao qual se refere o termo, porém, todas são desdobramentos do conceito deweyano primitivo, o qual Anísio Teixeira explicita do seguinte modo: dado o conjunto infinito de elementos da natureza em vários e múltiplos estados de interrelação, experiência é a ação de determinados elementos sobre outros e, simultaneamente, o sofrer dessa ação. Esse processo relacional termina por transformar a totalidade das partes envolvidas em algo novo. Tudo o que existe pode ser concebido segundo essas relações mútuas (TEIXEIRA, 1978, p.13).

Consequentemente, ressalta Teixeira (1978, p.13), esse conceito está longe de ser atributo puramente humano, já que contempla a atividade permanente de todos os corpos, uns com os outros. Contudo, há uma distinção muito importante entre a experiência que se passa no mundo biológico e no não-biológico. No plano biológico, as experiências tendem à conservação do organismo, o que não ocorre no plano não-biológico. Isso significa que, no plano da vida, há um telos nas experiências, o qual não é presente no outro plano. Esse telos é o que impulsiona o organismo a adaptar-se ao ambiente, à situação atual.

Essa adaptação, ocasionada por meio da ação e reação do organismo na busca de seu equilíbrio em frente à situação, ganha um elevado nível de complexidade quando se trata do ser humano, por exemplo, no que tange à esfera psicológica. Diz, Anísio Teixeira (1978, p.13-14, itálicos do autor):

no plano humano, esse agir e reagir ganha sua mais larga amplitude, chegando não só à escolha, à preferência, à seleção, possíveis no plano puramente biológico, como ainda à reflexão, ao conhecimento e à reconstrução da experiência. Experiência não é, portanto, alguma coisa que se oponha à natureza, - pela qual se experimente, ou se prove a natureza. Experiência é uma fase da natureza, é uma forma de interação, pela qual os dois elementos que nela entram - situação e agente - são modificados.

Por seu caráter de finitude, qualquer experiência não ocorre mais de uma vez, mas pode ser reconstruída, o que significa uma nova experiência referida a uma experiência que se findou. Por esse motivo, a experiência de reconstrução acaba por resultar, em última instância, em elementos distintos dos elementos iniciais da mesma.

Sobre o conceito em si, por exemplo, poder-se-ia considerar o empinar pipa como uma experiência, dentro da qual são denominados como elementos em interação o vento a linha, o carretel, a luz e o calor solares que inundam o ambiente, o aroma e a cor da grama, o desejo, o interesse, o esforço e o medo da pessoa que pratica o ato de segurar a linha e a pipa, o som dos 
pássaros ou da voz de outras pessoas no local, a imaginação, a memória e o próprio pensamento que referencia outros elementos que não pertencem à situação atual.

Contudo, cada elemento que constitui essa experiência pode ser considerado uma experiência "em si mesma", composta, por sua vez, pela contraposição de outros elementos. Por exemplo, o vento, que é considerado um dos elementos que compõem a experiência de empinar pipa pode ser tomado como a experiência da relação entre os gases da atmosfera, a poeira e o vapor d'água. A própria pipa, considerada um dos elementos que compõem a experiência de empinar pipa, poderia ser considerada uma experiência "em si mesma", formada, por sua vez, por outros elementos como a ação da cola no papel e nas varetas ou a tensão mecânica criada pelo estiramento da linha.

Quando há, pois, a referência a um fenômeno como experiência, é importante salientar que esse fenômeno, enquanto tal, pode, em si, ser referido como um feixe de experiências em interação e continuidade, considerando que o próprio processo de referenciação é uma experiência de linguagem. Desse modo, fica claro que conceber a realidade a partir do conceito de experiência implica, ao mesmo tempo, o abandono da noção absoluta de substância - tal como Aristóteles ou mesmo Descartes a concebiam - e a adoção de uma cosmovisão fundada na relação transitória e contingente entre elementos.

Sobre o conceito de experiência, diz, Ghiraldelli (2008, p.122):

em vez de falarmos de coisas, vamos falar de relações. Podemos continuar
usando os termos que até então estávamos usando, um tanto reificados como
pedra, homem, terra, leão, computador, amor e frauda. Claro, não há razão
para se abandonar de uma hora para a outra nossa linguagem, que é nosso
pensamento. Mas podemos imaginar que cada uma dessas 'coisas' é um feixe
contingente de relações. Assim, quando fazemos isso, nos libertamos da ideia
de substância - algo perene, imutável, que seria o núcleo de cada coisa - e
passamos a viver com a ideia de que tudo está em contínua mudança segundo
as relações que vão se estabelecendo. Essas relações podem ganhar nomes
diferentes, segundo o campo que recortamos para conversar, falar, estudar ou
investigar. Um desses nomes é "experiência".

Em Dewey e, consequentemente, em Kilpatrick, a referência ao conceito experiência é sempre feita por meio da enunciação do termo acompanhado de um qualitativo, por exemplo: experiência educativa, experiência de aprendizagem, experiência autoconsciente; ou pela referência implícita a algum qualitativo, por exemplo, a expressão "educação pela experiência significativa", que significa "a experiência individual da reconstrução de experiências findas e cujo processo ocorre pelo confronto entre o significado dessas últimas e os significados oriundos das novas situações vivenciadas pelo indivíduo". 
Por exemplo, em uma aula de ciências, antes de o professor explicitar os princípios que regem os fenômenos naturais, é de praxe que se realizem experimentos com a participação dos estudantes, de forma que os significados depreendidos a partir da interação (experiência) estudante-processo de experimentação possam, posteriormente, ser reconstruídos de outro modo pelo primeiro, possivelmente de uma forma mais abstrata e generalizada.

É notório que compreender o pragmatismo deweyano implica considerar os próprios termos sob regime do conceito nuclear de experiência. Um exemplo é o conceito de conduta, presente em A Natureza Humana e a Conduta; sob a ótica deweyana, conduta pode ser entendida, por exemplo, como experiência prática (ANDRADE; CUNHA, 2019, p.341). Porém, para que se compreenda a fundo o significado desse conceito não basta correlacioná-lo a expressões análogas, é preciso, antes, vislumbrar sua raiz ontológica, a saber, o entrecruzamento de certos feixes de experiências reflexivas do indivíduo-em-relação-aoambiente.

Evidentemente, a leitura de qualquer filósofo exige que se considere os termos em sua completude e especificidade teórica. O exemplo a partir da expressão "educação pela experiência" ou do conceito de "conduta" sugere que a compreensão do que significam esses termos segundo apenas o dicionário não é suficiente para compreender o papel que os mesmos - enquanto referentes e/ou referidos - desempenham dentro da filosofia do autor.

Ademais, os exemplos dados também revelam o quão primitivo e inclusivo é o conceito de experiência. Se ao se referirem à experiência prática, Andrade e Cunha houvessem dito apenas "experiência", o termo não alcançaria o nível de distinção necessário para transmitir com exatidão a mensagem.

O conceito de experiência perpassa toda a obra de Kilpatrick, na qual é frequentemente utilizado em referência à esfera pessoal, como experiência reflexiva individual. Essa natureza de experiência individual, em Kilpatrick, é consoante àquilo que Anísio Teixeira (1978) bem explicitou em A pedagogia de Dewey, a saber: uma experiência em nível biológico que, em última instância, representa um esforço adaptativo do organismo diante de uma situação atual.

Em Kilpatrick, a experiência reflexiva resulta em aprendizagem, a qual é inerente à própria vida humana em seu sentido biológico e psicológico. Nas palavras do autor:

por experiência nós queremos dizer, pois, um específico tipo de conteúdo da vida, o conteúdo da vida tal como um ser autoconsciente se coloca em interação ativa com seu ambiente. A partir disso segue que, conforme dissemos antes, a unidade de estudo não é a própria pessoa, nem mesmo a pessoa sozinha tomada "em sua completude", mas a pessoa-em-ativainteração-com-seu-ambiente. A situação a desestabiliza; a pessoa, então, se sente afetada por aquilo e responde ativamente: primeiro, sentindo-se 
provocada; depois, passa a avaliar a situação, a planejar metas e meios para controlar a situação e, finalmente, a tentar a efetivação do real controle. [...] Experiência, portanto, em um sentido verdadeiro é um tipo de vida em que os estágios iniciais permeiam, através da aprendizagem, os estágios posteriores para moldar esses esforços adicionais (KILPATRICK, 1951, p.23-24, tradução nossa).

Desse modo, o autor torna patente a indissociabilidade indivíduo-sociedade, do ponto de vista deweyano da experiência. Porém, Kilpatrick pontua, nesse excerto, um segundo pilar teórico: o pensamento Charles Darwin exposto em A origem das espécies, do qual são pontuados, especificamente, dois atributos da natureza: interação e mutabilidade. Esses atributos, assim como o conceito de experiência de Dewey, são dois dos pilares do pensamento kilpatrickiano. Sobre a interação e a mutabilidade, diz Kilpatrick (1951, p.19, tradução nossa, grifos nossos):

em Darwin, a mudança - mesmo da natureza do próprio homem - foi o conceito essencial. [...] Aqui, dois resultados da posição de Darwin nos interessam [...]: primeiro, o processo de mudança tornou-se o principal conceito na compreensão dos assuntos humanos, tanto no desenvolvimento individual quanto no da civilização; segundo, o comportamento biológico, o comportamento do homem ao enfrentar uma situação para controlá-la tornouse a chave para o estudo do processo da vida, tanto do indivíduo (psicologia, psicologia) quanto do grupo (sociologia, história, política, economia).

A afirmação de Darwin de que os aspectos de mutabilidade e interação são inerentes ao processo da vida significou para Kilpatrick que se a sociedade pretendesse caminhar para uma situação econômica, social e política mais justa, não poderia continuar a carregar uma visão estática de mundo. Sociedade e indivíduo interagem dialeticamente e, nessa interação, transformam-se, ambos, em algo novo. E diante desse movimento complexo, Kilpatrick questiona-se sobre o papel da educação e, particularmente, sobre a educação anacrônica pautada em um currículo prefixado.

Essa é uma das questões que este trabalho pretende responder, sob a ótica de Kilpatrick. Porém, ao mesmo tempo em que Kilpatrick, incomodado com essa questão, buscou respostas, várias foram as críticas acerca de seus posicionamentos como pedagogo. No cerne de algumas dessas críticas encontra-se a discussão sobre a centralidade do estudante no paradigma pedagógico, expressa por uma frase conhecida atribuída à escola nova: "ensinamos crianças, não matérias". 


\subsection{O CERNE DO PROCESSO PEDAGÓGICO E A SUPERAÇÃO DA DICOTOMIA INDIVÍDUO-SOCIEDADE}

A discussão acerca do protagonismo do professor, do aluno ou da técnica no processo pedagógico é um dos pontos nevrálgicos da discussão a partir da qual a pedagogia renovada tece sua crítica à pedagogia tradicional. Ressalta-se que essa discussão gerou, inclusive, uma cisão interna à pedagogia renovada, cisão, essa, provocada por algumas distinções entre a visão pedagógica de Dewey e a de Kilpatrick.

Antes de tudo, é preciso ter em mente que, ao longo dos anos, o pensamento filosófico de Kilpatrick passou por uma expansão de horizontes, principalmente no que tange à relação indivíduo-sociedade.

Em Método de Projeto, por exemplo, é possível observar um Kilpatrick que busca uma transformação escolar e enfaticamente didática, a qual foi arquitetada e justificada sob o darwinismo e o pragmatismo deweyano. Esses, por sua vez, vistos sob esse prisma pedagógico, pressupõem que a natureza está em permanente evolução biológica e a educação, assim como o comportamento, são, ao mesmo tempo, processos e instrumentos por meio dos quais essa natureza regula a interação organismo-ambiente. Nessa obra, Kilpatrick discorre sobre esse processo regulatório com vistas à sua aplicação no ambiente escolar.

Em Fundamentos do Método, por sua vez, é possível encontrar, segundo Cremin (1961, p.217), os princípios pedagógicos presentes em Método de Projeto mais bem desenvolvidos, dentre os quais estão a noção deweyana aprimorada de uma escola como um ambiente social depurado e a questão específica do método, a qual preconiza um ambiente educacional pensado de forma a torná-lo o mais próximo possível da vida mesma. Essa obra fora elaborada com base em um curso denominado Fundamentos do Método, ministrado por Kilpatrick durante alguns anos na Universidade Columbia.

Desse modo, aparentemente, a proposta de Kilpatrick pode soar não-diretiva. Porém, Lourenço Filho revisita Filosofia da Educação, de Kilpatrick, e elucida essa questão com o seguinte trecho:

a nova educação acentua a atividade finalista; a velha educação a punha de lado, negando-lhe qualquer valor. Para realizar uma atividade finalista producente, a unidade típica dos procedimentos escolares deverá ser, portanto, o propósito pessoal, porque ao mesmo tempo em que respeita a identidade pessoal, apoia a democracia, cultivando os atributos necessários ao seu exercício: respeito por si mesmo, autodireção, iniciativa, ação dirigida pelo pensamento, autocrítica e persistência (KILPATRICK, 1951 apud LOURENÇO FILHO, p.299-300). 
Nesse sentido, o método de projetos visa a, democraticamente, formar para a democracia. Essa é uma das tarefas da educação, segundo Kilpatrick, e, por outro lado, não há como desenvolver o espírito democrático nas pessoas se não houver princípios e objetivos pedagógicos norteadores da prática educacional. Desse modo, a pedagogia defendida por Kilpatrick em nada se relaciona a uma pedagogia não-diretiva. Não há espontaneísmo em Kilpatrick. O que há é liberdade sob regime de responsabilidade em meio a um ambiente social pedagogicamente arquitetado.

Por sua vez, a articulação kilpatrickiana entre a visão pragmatista-darwiniana e o processo educacional também se dá por meio da referência à psicologia e à ética expressas em A Natureza Humana e a Conduta e Interesse e esforço, e também por meio da referência às leis de aprendizagem de Thorndike, expressas em Psicologia Educacional.

\subsubsection{A centralidade do educando no paradigma pedagógico: distinções entre Dewey e Kilpatrick}

Segundo Cremin (1961, p.217-218), embora Kilpatrick se propusesse a manter uma postura filosófica e pedagógica de superação da dicotomia entre "ensinar matérias" e "ensinar crianças", tanto em Método de Projeto quanto em Fundamentos do Método, o autor inevitavelmente favorece uma abordagem centrada na criança. E continua, Cremin: "Essa tendência é claramente fortalecida por seu incisivo ataque ao que ele [, Kilpatrick,] chamou de assunto-matéria extrínseco, ou assunto-matéria 'prefixado'.” (CREMIN, 1961, p.217-218, tradução nossa).

Mas, por que Kilpatrick, em suas primeiras obras, defenderia uma pedagogia centrada no estudante?

$\mathrm{Na}$ verdade, a partir de dois elementos deweyanos, o conceito de experiência e o princípio de continuidade (COSTA, 2016), Kilpatrick reconhece haver na experiência de aprendizagem a dependência ôntica que todo novo saber estabelece em relação ao antigo, o que poderia significar, em termos estritamente epistêmicos, a valorização radical do encadeamento lógico de matérias em vez da valorização do conhecimento originário do interesse pessoal dos atores diretamente envolvidos.

Porém, Kilpatrick afirma que, historicamente, essa dependência do novo em relação ao velho não se deu de modo equivalente entre os diferentes tipos de experiências humanas, haja vista o descompasso entre a organização sócio-econômica, de então, e os valores democráticos. 
Esse descompasso é razão suficiente para que, diante do espectro curricular cujos extremos são, cada qual, "ensinar matérias" e "ensinar crianças", ou, em outros termos, "saberes prefixados" e "saberes circunstanciais", Kilpatrick visse com descrença o encadeamento lógico que rege a prefixação dos conteúdos. Para Kilpatrick, a história mostrou que as mudanças, por ocorrerem de modo caótico, não deixam para a escola outra alternativa senão a de desenvolver a moralidade, as preferências e a ação da inteligência, que são capacidades individuais. E essas capacidades individuais, segundo o autor, não somente resistirão ao mundo em mudança como permitirão que essa mudança se dê em função de um nível cada vez maior de intencionalidade.

Portanto, a escola, segundo esse pressuposto, deve ensinar métodos de investigação e de confirmação dos saberes postos pela sociedade e pela ciência, pois, caso contrário, a escola estaria tornando a sociedade ainda mais estática e, consequentemente, ampliaria ainda mais o descompasso entre a transformação econômica e as mudanças culturais e éticas.

Desse modo, para o Kilpatrick de Método de Projeto e Fundamentos do Método, os assuntos-matéria do currículo jamais deveríam ser prefixados; os alunos os traríam para a sala de aula por si mesmos por meio de atividades propostas e planejadas por eles mesmos. E nesse aspecto há diferenças em relação a Dewey. Diz, Cremin (1961, p.219-220, tradução nossa):

Dewey preocupava-se com os interesses e propósitos das crianças, mas sua empreitada na Escola Laboratório era desenvolver um novo currículo para assumir o lugar do antigo - um novo corpo de assuntos-matéria, melhor ordenado e delineado, o qual iniciaria com a experiência dos aprendizes e culminaria com os assuntos organizados que representariam a experiência acumulada no trajeto. Kilpatrick, por outro lado, em sua ênfase sobre o futuro incerto e seu inflexível ataque à prefixação dos assuntos-matéria, revela, em última instância, descrédito aos assuntos organizados e, dessa forma, altera o equilíbrio do paradigma pedagógico deweyano em direção à criança. A [questão] da centralidade [extrema] na criança chamou atenção até mesmo de Dewey, que a rejeitou, primeiramente em The Child and the Curriculum (1902) e depois em Experience and Education (1938).

Ainda assim, se por um lado, Kilpatrick distancia-se de Dewey em relação à centralidade do educando no paradigma pedagógico, conforme afirmou Cremin, por outro, Kilpatrick concorda com Dewey que, diante dos efervescentes impulsos econômicos e sociais, frutos do avanço científico e industrial, a escola necessita transformar-se completamente (ibidem, p.218, tradução nossa).

Partindo desse objetivo, em Fundamentos do Método, Kilpatrick evidencia sua crítica a uma educação limitada ao behaviorismo não apenas em função dos testes escolares padronizados, mas também em função de seus pressupostos metodológicos de pesquisa, os quais se utilizavam prioritariamente da aplicação de estímulos prefixados ao organismo. 
Segundo Kilpatrick, uma psicologia que se embasa em estímulos prefixados do ambiente não está à altura de oferecer à educação princípios de aprendizagem que sejam efetivos em meio a uma sociedade dinâmica.

Aliás, Cremin (1961, p.218-219) confirma a posição de Kilpatrick, posta em Fundamentos do Método, acerca da prefixação de conteúdos e ressalta que essa posição será o ponto nevrálgico para o desenvolvimento de Educação para uma Civilização em Mudança.

Diante da importância dessa questão, é possível destacar, em Fundamentos do Método, um trecho do diálogo no qual dois interlocutores discutem sobre a diferença entre ensinar aos alunos "o quê pensar" e ensiná-los "como pensar". As personagens do diálogo utilizam-se do exemplo de dois professores hipotéticos, dentre os quais um referencia uma sociedade estática e o outro, uma sociedade dinâmica:

[Personagem A:] "Imagine dois professores: um sabe exatamente o que seus alunos ou eles todos enfrentarão; o outro sabe (ou pensa que sabe) algumas coisas as quais terão de enfrentar, mas, sabe, principalmente, que eles irão enfrentar mudanças inevitáveis e cada vez mais rápidas, em direções desconhecidas. Agora, eu pergunto, ambos deveriam conduzir suas aulas de modo semelhante?"

[Personagem B:] "Acho que não. O professor da sociedade fixa saberá previamente as respostas às questões que seus alunos encontrarão. Ele, inclusive, pode ensiná-las na forma com a qual seus alunos precisarão sabêlas. Mas o professor da sociedade em mudança não poderá fazê-lo. Realmente não sei o que ele pode fazer."

"O ensino para ele torna-se um problema diferente, não é?"

"Com certeza. Nunca pensei sobre isso dessa forma."

"O professor da sociedade fixa pode ensinar ao seus alunos o quê pensar, você diz, mas o outro não."

"E quanto a ensinar como pensar? Digo, como dar conta dos problemas? Como agir diante de situações difíceis? O professor da sociedade em transformação não poderia fazê-lo?"

"[Talvez, se] as escolas trabalhassem de modo diferente. Elas não poderiam?" "Sim, é mesmo. Agora eu compreendi. Enquanto as pessoas olhavam para o mundo como fixo e estático, elas punham as crianças para, principalmente, memorizar respostas às perguntas que um dia pudessem encontrar. Memorização e adequação a uma ordem fixa, ou seja, habituação; é o tipo de escola que nos acostumamos a esperar, e o tipo que elas realmente tiveram. Interessante, não?"

"Sim; e se pessoas enfrentassem mudanças cada vez mais aceleradas e transformações no mundo de forma inesperada e em direções inesperadas, e então?"

"Então, a educação delas deveria enfatizar o pensar, os métodos de resolução e princípios de ação, mais que meramentte o que fazer. É claro. Tal escola deveria tentar formar pessoas independentes e adaptáveis (KILPATRICK, 1925, p.266-67, tradução nossa).

Primeiramente, esse excerto explicita que Kilpatrick, depois de haver exposto sua concepção pedagógica em Método de Projeto e Fundamentos do Método, passou a considerar 
de forma mais pontual as demandas pelas quais a escola deveria responsabilizar-se. Demandas, essas, que seriam abordadas com afinco em Educação para uma Civilização em Mudança.

Em segundo lugar, o excerto torna notória a visão do autor de que as permanentes mudanças da sociedade de fato reforçam o antagonismo entre a educação nova e a tradicional, não somente em relação à questão didática, mas, antes, em relação ao equilíbrio entre permanência e transitoriedade de saberes, costumes e valores.

Mesmo do ponto de vista didático, esse equilíbrio não pode ser definido apenas por seus extremos: "ensinar matérias" ou "ensinar crianças". Em outras palavras, Kilpatrick não estabelece uma hierarquia entre o pensar e o agir, já que, segundo seu conceito de educação, o pensar é concebido como um comportamento, assim como o agir. A distinção entre ambos se dá unicamente em função de sua natureza, o que, do ponto de vista curricular, implica uma visão mais complexa acerca do significado para o estudante do conteúdo escolar que a visão posta pela pedagogia tradicional. É preciso, segundo Kilpatrick, encontrar um "equilíbrio dinâmico" entre as demandas sociais e os interesses dos educandos, equilíbrio, esse, mais bem explanado em Educação para uma Civilização em Mudança, sem o qual não há efetiva aprendizagem.

\subsection{PENSAR EDUCAÇÃO E SER HUMANO EM MOVIMENTO}

Em 1926, Macmillan publicou Educação para uma Civilização em Mudança, uma compilação de três palestras proferidas por Kilpatrick na Universidade Rutgers no mesmo ano. Essa obra, como dito anteriormente, evidencia um passo importante do autor na direção de uma concepção mais dinâmica de ser humano.

Para Kilpatrick, a segunda metade da década de 1920 foi um período de autoquestionamento em relação à centralidade do estudante no paradigma pedagógico.

As palestras proferidas em 1926 e que, no mesmo ano, compuseram Educação para uma Civilização em Mudança, tinham como escopo analisar e diagnosticar o descompasso existente entre: a) o ritmo de desenvolvimento tecnológico na comunicação, no transporte e no setor bélico e b) o necessário ritmo de desenvolvimento espiritual segundo o qual se alcançaria a necessária maturidade ética, cultural e política para assegurar uma vida democrática e humana.

Diante desse descompasso, o autor buscou apontar o papel da educação. Essas palestras não visavam a propor, por exemplo, meios de promoção de reformas sociais de modo a eliminar 
as desigualdades. Evidentemente que Kilpatrick não as ignorava, porém, não as considerou sob os mesmos termos sob os quais, por exemplo, eram tratadas pelos marxistas.

O contexto no qual Kilpatrick formula o conteúdo dessas palestras remonta ao período imediatamente anterior à data na qual foram proferidas, dentro da década de 1920; período, no qual, a população urbana estadunidense passava por uma situação econômica relativamente estável ao mesmo tempo em que a aquisição de bens materiais e tecnológicos e o poder da comunicação, do transporte e do setor bélico intensificaram-se.

A importância da análise dessa obra, além do fato de ser uma das poucas que possuem versão em português, além das já citadas Democracia e o respeito da personalidade (KILPATRICK, 1942) e A Filosofia da Educação de Dewey (idem, 1953), repousa na possibilidade de cotejamento entre o pensamento do autor e duas de suas principais matrizes teóricas: John Dewey e Edward Lee Thorndike.

Como foi dito, Educação para uma Civilização em Mudança acabou por se constituir como uma espécie de antessala do pensamento kilpatrickiano para os educadores brasileiros. Inclusive, é a obra mais difundida entre as bibliotecas universitárias do país.

A tese principal do autor é a de que a sociedade estadunidense está mudando em um ritmo inédito, e essa mudança ocasionou novas exigências à educação, a qual, para enfrentar a nova ordem social e tecnológica em marcha, necessitará também de mudanças.

Kilpatrick, diante desse diagnóstico, indaga-se se seria, essa mudança, um aglomerado caótico de possibilidades ou, no interior desse caos, seria possível identificar tendências.

A resposta de Kilpatrick, evidenciada nos parágrafos anteriores, sugere que, é possível, de fato, notar a presença de certos elementos cuja expansão é indubitável, como a comunicação, o transporte - tanto em velocidade quanto em grau de generalização - e o poder bélico (KILPATRICK, 1978, p.15). O que leva à segunda indagação de Kilpatrick, a saber: haveria um fator comum que sustente tais tendências?

A resposta do autor é afirmativa, e esse fator é "o pensamento baseado na experimentação, ou, de modo geral, o desenvolvimento da ciência e de suas aplicações à atividade humana" (ibidem, p.16, grifos do autor).

Na sequência dessa afirmação, Kilpatrick demonstra historicamente como a civilização ocidental extrapolou a utilização da lógica experimental, própria da ciência, para incorporá-la como paradigma de comportamento. 


\subsection{O MÉTODO EXPERIMENTAL}

Para o autor, o chamado mundo moderno, que se apoia na comprovação da teoria pela observação dos fatos, apresenta-se para as pessoas como algo tão razoável que, para compreendê-lo ou mesmo para inferir a gênese de seu principal atributo - a mudança - é preciso remontar à história para, nessa, localizar e evidenciar o início de uma nova epistemologia.

O pensamento baseado na experimentação não é algo recente à época de Kilpatrick. Segundo o autor, essa concepção remonta a Galileu e expressa um modo de conhecer que não se circunscreve a uma epistemologia estritamente argumentativa, ou mesmo dogmática como fora a dos escolásticos. A ruptura epistemológica entre o antigo e o moderno se dá justamente no "princípio que Galileu introduziu ao demonstrar que o pensamento, para ser aceitável, precisa ser comprovado em suas consequências práticas." (KILPATRICK, 1978, p.17, itálico do autor).

Em Platão, o pensamento é epistemologicamente considerado superior à sensação, e a mente, considerada superior à matéria. Na escolástica, ocorre que, moralmente, o espírito é superior ao corpo. A partir disso, é notório o quão grande fora a inversão praticada por Galileu ao subordinar o espírito e a mente ao regime sensorial, especialmente no que tange à noção das pessoas acerca do caráter teleológico da própria existência.

Do princípio ensaiado por Galileu pode-se inferir que a despeito da incompletude da ciência, com ele é possível acumular continuamente material de pensamento sobre o qual se pode depositar inteira confiança. Não é possível atribuir-lhe estatuto de "Verdade", porém, ser considerado como "verdadeiro" é suficiente para que esse pensamento seja digno de crédito, mesmo que de forma provisória.

Corolária à prática científica da experimentação seguiu-se não somente a tendência de aplicar os resultados científicos à melhoria da vida humana material, mas também a influência desse tipo de pensamento na própria concepção da vida e nas atitudes do homem para consigo mesmo (ibidem, p.19).

Para Kilpatrick, o pensamento baseado na experimentação sustenta três profundas tendências da vida moderna: a) uma atitude mental, diante da vida; b) a industrialização; e c) a democracia. Da análise dessas, segue o objetivo maior da obra Educação para uma Civilização em Mudança, que é o de apontar tendências do mundo moderno e explicitar as possíveis consequências para a educação. 


\subsubsection{O método experimental: do laboratório para a vida}

Por transformação do ponto de vista mental entende-se a mudança de uma moral negativa para uma moral positiva, ou, dito de outro modo, de um sentimento de incompletude para um sentimento de fé na ciência e em si mesmo como ser humano.

A moralidade derivada do cristianismo ocidental supõe que o homem é um ser dotado de pensamento falível e, por conta dessa falibilidade, não deve ser deixado por si próprio (KILPATRICK, 1978, p.21). Sem o auxílio divino, da bíblia e da teologia, o homem jamais seria capaz de conduzir um juízo de valor que o levasse a uma vida realmente mais digna. Desse modo, diante do mistério que envolve as leis naturais e de um contexto desprovido de verificações empíricas, a argumentação teológica deveria bastar.

A passagem de uma visão negativa de homem, que enfatizava aquilo que lhe falta, para uma visão positiva, que visa ao progresso apesar da incompletude do conhecimento, motivou a fé no método científico. A conduta passiva diante do mundo natural fora modificando-se para uma conduta ativa, em cujo processo se deu uma transformação não apenas de caráter epistemológico, mas também de caráter passional.

\subsection{A CRÍTICA ÀS INSTITUIÇÕES}

Assumir a crença no método baseado na experimentação significou, corolariamente, autorizar a crítica contra as instituições, sejam essas a religião, a família, a moral, o sistema econômico, a propriedade, a guerra ou o próprio Estado (KILPATRICK, 1978, p.22).

Nesse sentido, a crítica às instituições ou mesmo as justificativas para sua existência passaram a obedecer ao critério das consequências reais, embora juntamente com esse critério estava o problema metodológico de como avaliar as consequências, visto que as condições de dentro e de fora do laboratório são diversas. Porém, o próprio progresso, frequente e irrefletidamente tido como paradigma, poderia, então, tornar-se alvo de crítica.

Do ponto de vista moral, a crítica às instituições provocou mudanças profundas no sentido da vida humana, que outrora fora dominado por um único paradigma e que, agora, encontra-se cindida em pelo menos dois: o tradicional, ancorado no passado, e o experimental consequencialista, ancorado no presente. Sendo que, para esse último, as instituições foram feitas do homem para o homem e, portanto, do ponto de vista ético, deverão ser julgadas segundo sua contribuição para o bem comum (ibidem, p.23). 
Diante desse quadro, Kilpatrick afirma que o paradigma experimental consequencialista, enquanto modo de pensar a própria vida, tende a se difundir entre os membros da sociedade, e essa é a primeira tendência da sociedade a partir de Galileu.

\subsection{INDUSTRIALIZAÇÃO E INTEGRAÇÃO SOCIAL}

A segunda tendência moderna é a crescente industrialização, cujo efeito mais evidente é a integração social, ou seja, a maior dependência entre os homens (KILPATRICK, 1978, p.24).

A maquinofatura e a produção em larga escala fez com que houvesse a centralização na cidade da produção de muitos bens, produção, essa, feita anteriormente de modo integral pelos artesãos das próprias comunidades para, logo em seguida, serem conduzidas e organizadas pelos comerciantes locais.

$\mathrm{Na}$ fase artesanal, cada comunidade era capaz de manter-se por si. Com a manufatura, houve o início de uma maior interdependência entre produtores da matéria-prima e os artesãos, o que culminaria na forte divisão do trabalho em escala local e mais tarde em escala regional e mundial.

A crescente interdependência humana produzida pela interdependência do processo produtivo trouxe correlatamente a integração social do indivíduo, principalmente em função da expansão dos meios de comunicação.

As consequências para o conhecimento e o saber humanos ocasionadas pela expansão da comunicação e pela crescente velocidade de difusão da informação são: a) a transitoriedade do saber humano e b) o descompasso entre as pessoas que possuem meios eficientes de se comunicar e as que não os possuem.

A reorganização do espaço em função de fatores econômicos fora outra consequência da industrialização, já que ao mesmo tempo em que as fábricas se multiplicaram, a cidade expandiu-se em função do aumento expressivo da migração de trabalhadores vindos do campo.

O mundo visto através da comunicação mais rápida passa a se parecer menor, ao mesmo tempo em que, gradativamente, o poder da propaganda e dos artefatos tecnológicos - inclusive para substituir a mão-de-obra humana - vão minando o poder político do indivíduo e tornando-o a cada dia menos capaz de posicionar-se.

A dependência econômica do outro também aumentou na medida em que se intensificara a relação hierárquica intra e entre corporações. Ou seja, houve o aumento na 
proporção das pessoas que trabalham sob a autoridade de outrem em lugar de dirigirem os seus próprios negócios (ibidem, p.26).

Em suma, Kilpatrick afirma que, diante desse cenário, ao mesmo tempo em que há a maior interdependência entre as pessoas, há, paradoxalmente, um processo subjetivo de atomização com consequências políticas radicais, pois

há menor oportunidade e encorajamento para compreensão do porquê das coisas. O homem comum sente que, cada vez mais, o seu pensamento é elaborado por outros. E sente, assim, que o valor de sua opinião pessoal diminui proporcionalmente. [...] Surge, desse modo, a chamada atitude do "fatalismo das massas", a crença de que, com grande multidão a convencer, o pensamento tem pequeno papel a desempenhar. A responsabilidade pessoal tende a diminuir. [Dessa situação,] segue-se facilmente [para] um individualismo egoísta (KILPATRICK, 1978, p.26, itálicos e aspas do autor).

A terceira profunda tendência moderna é a democracia, que, num primeiro olhar, apresenta-se como uma tendência contraditória em relação às outras duas.

\subsection{A DEMOCRACIA COMO VIDA MORAL}

Em Kilpatrick, assim como em Dewey, o significado de democracia não se restringe à designação de forma de governo, mas, em primeiro lugar, significa que "cada indivíduo deva figurar como uma pessoa e assim ser tratado." (ibidem, p.27, grifo do autor).

Em segundo lugar, democracia supõe que o mundo e as instituições são do homem e para o homem, para desenvolvê-lo e servir-lhe de expressão. Diz, Kilpatrick:

[se] o homem só vem a ser homem em sociedade, cada qual deve desenvolverse e exprimir-se de tal forma que, da própria expressão, resulte simultaneamente o desenvolvimento e a expressão de todos juntos. Nenhum homem capaz [de expressar-se] deverá ficar à margem (ibidem, p.28, itálico do autor).

Sobre esse excerto, vale ressaltar que Kilpatrick explicita do ponto de vista político uma determinada visão acerca relação indivíduo-sociedade que remete à noção de sujeito proposta por George Herbert Mead, noção, essa, abordada com maior profundidade no item quatro deste trabalho.

Embora a ideia de democracia, como a concebe Kilpatrick, seja aparentemente estranha à tendência moderna de industrialização, o autor opõe-se à existência de uma contradição $a$ priori entre ambas. Para Kilpatrick, ocorre de fato uma contradição entre ambas quando à industrialização se permite o correr livre e desorientado. Em outros termos, equivaleria a dizer 
que a ética do "livre mercado", que preconiza produtividade em detrimento de condições dignas de trabalho e de vida, guarda em si a tendência de conduzir o homem à barbárie.

A democracia, para Kilpatrick, é uma exigência básica da moral moderna e deve nortear a industrialização, pois,

a democracia sobretudo representa vida moral. [...] [É] um esforço para fundar a sociedade num princípio moral: a cada um se deve oferecer simultaneamente oportunidade de desenvolvimento e expressão individual, até o ponto máximo que seja possível (ibidem, p.28, itálico do autor).

E o que significa vida moral para Kilpatrick?

Democracia e vida moral são imbricados e interdependentes. Vida democrática, como foi dito, implica uma vida com responsabilidade e liberdade radical de expressão. Para Kilpatrick, a moral segue a mesma lógica da democracia, pois sustenta-se na autoridade interna do indivíduo e não na autoridade externa, como ocorre no autoritarismo. Desse modo, a distinção entre autoridade democrática e autoritarismo repousa, justamente, na distinção entre autoridade interna e externa.

Conceitualmente, autoridade, para Kilpatrick, é a regra ${ }^{2}$ que a inteligência aceita ao considerar, sem preconceitos, a situação como ela, de fato, é. Trata-se de uma percepção do ambiente pelo indivíduo que é o menos possível mediada por outrem. A partir dessa percepção mais direta, a escolha do indivíduo será encarada por esse como necessária devido a uma postura interna - ou em outros termos, intrínseca ao indivíduo -, a qual é inerente ao próprio funcionamento da conduta (KILPATRICK, 1978, p.29).

Radicalmente oposta à autoridade interna, a autoridade externa supõe a aceitação incondicional e indeliberada de uma regra pelo indivíduo, perante à qual esse se inclina, seja pela imposição da tradição ou por qualquer outra razão senão a de sua existência. A autoridade, quando assim exercida, é alheia, externa ao indivíduo a quem é imposta - ou, em outros termos, é uma autoridade extrínseca ao indivíduo (ibidem, p.29). Nesse sentido, a transformação, por exemplo, de uma sociedade teocrática em uma sociedade democrática implicaria a mudança de uma forma de autoridade externa para uma de autoridade interna.

Um exemplo de autoridade externa, dado por Kilpatrick, são os adultos que ensinam às crianças o que é certo ou errado a partir de argumentos de autoridade tradicional: "Isso é errado porque na Bíblia está escrito o contrário do que você está fazendo!" ou "Eu ensino a você proceder dessa forma pois meu pai me ensinou assim e o pai dele idem!”. Nesse sentido, é

\footnotetext{
${ }^{2}$ Observa-se, apenas, que embora Kilpatrick aparentemente estabeleça do ponto de vista gramatical uma relação de identidade entre "autoridade" e "regra", a "autoridade", nesse caso, é identificada com "estado peirceano de crença", ao passo que "regra" corresponde ao "conteúdo da crença" em si.
} 
possível que, aos olhos de terceiros, a criança passe a agir conforme o que foi prescrito pelo adulto, porém, internamente, não é garantido que esteja ocorrendo o mesmo.

Por conta da possibilidade de desencontro entre as atitudes externa e interna, é preciso que se eduque por meio do diálogo motivado por porquês justificadores da conduta (ibidem, p.31-32).

A justificativa psicológica para os porquês se dá por meio da referência ao conceito peirceano de crença, como afirmado anteriormente, e ao conceito de aprendizagem do ponto de vista deweyano.

A palavra porque provocaria, segundo Peirce, um infinito número de experiências intelectivas cujas consequências são a mudança de um estado de crença para um estado de dúvida e depois para um processo de fixação de novas crenças (WAAL, 2007, p.32-39).

Em Dewey, por sua vez, o interesse em inquirir, movido por um porquê, leva a pessoa a considerar a situação, a levantar hipóteses, a considerar a validade dessas hipóteses e suas consequências éticas e a agir em função do resultado desse processo de deliberação e de ressignificação da realidade.

Por exemplo, o debate sobre questões de gênero inclui o porquê de homens e mulheres, ao trabalhar na mesma função, receberem frequentemente salários desiguais. Há várias justificativas para essa desigualdade, como a possibilidade de a mulher afastar-se do trabalho por conta da maternidade e com isso oferecer "menor produtividade", ou mesmo por um juízo de valor que considera a austeridade ou força física como fatores determinantes de poder sobre os outros.

De qualquer modo, a despeito do número de justificativas ou de sua plausibilidade, a mudança de uma situação injusta, como o caso da desigualdade de salários entre homens e mulheres, para uma situação de maior justiça se dá por meio de um porquê filosófico. Nesse sentido, é necessário que as pessoas intencionalmente se envolvam pela e na situação de injustiça e, por meio da reflexão e do questionamento do status quo, desenvolvam a aprendizagem e, então, tornem-se pessoas mais justas.

\subsection{A MUDANÇA COMO PARADIGMA EDUCATIVO}

A mudança como paradigma educativo é tida como meio e como fim. Diz Kilpatrick: “a experimentação no pensamento social e moral tem agido por duas vias: uma, para quebrar a autoridade como era concebida, a outra para espalhar o hábito geral de indagar [acerca] dos porquês [das coisas].” (KILPATRICK, 1978, p.32, itálico do autor). 
Quanto à tarefa da educação moral, Kilpatrick afirma que é preciso fazer a mudança da autoridade externa para a interna, sem que essa mudança signifique um total abandono da autoridade externa enquanto ainda não foi construída a interna, principalmente quando concorrendo contra a fixação de princípios democráticos de ação está a mudança cada vez mais veloz dos costumes em função da descoberta de novas tecnologias e de sua cada vez mais rápida difusão entre as pessoas.

Mesmo diante de um quadro em que a vida cotidiana das pessoas é marcada pelo experimentalismo, pela interdependência econômica e atomização social e pelo embate entre autoridade interna e externa, Kilpatrick indaga-se sobre um provável declínio da marcha de mudança.

A esse respeito, o autor conclui que não há evidências que corroborem tal declínio, especialmente ao se considerar que o pensamento baseado na experimentação tende a formar uma quantidade cada vez maior de saberes, os quais são difundidos numa velocidade e num alcance geográfico cada vez maiores.

A mudança em progressão geométrica, decorrente desse processo, traz corolariamente mudanças sociais, porém, estas em uma cadência diversa da primeira. $\mathrm{O}$ descompasso entre os ritmos material e espiritual de mudança gerou uma tensão cada vez maior entre a visão tradicional de educação a visão de educação proposta por Kilpatrick, já que a primeira possui como pressuposto a valorização da permanência justificada por "razões" que estão fora e acima do homem, enquanto a segunda organiza-se em função da presente condição humana sob uma cultura científica experimental.

Mas, seria possível uma vida democrática sem qualquer elemento permanente? Sobre essa questão, primeiramente, Kilpatrick afirma que é preciso uma filosofia que considere a mudança em sua radicalidade, ou seja, que tenha como essência a mudança. Para elucidar essa tese, o autor recorre à história, especificamente a Heráclito, Aristóteles e Darwin.

Kilpatrick relembra que, primeiramente, Heráclito pensara o cosmo como essencialmente mutável. Porém, com Aristóteles a natureza passa a ser entendida segundo a coexistência de fatores mutáveis e imutáveis nos seres vivos.

Kilpatrick exemplifica historicamente o pensamento aristotélico referente à questão da mudança com o desenvolvimento de uma semente:

A mudança é o desenvolvimento para um alvo prefixado, como por exemplo, a semente se transforma em carvalho, a árvore desenvolvida. A semente é o carvalho em potencial. O carvalho, em pleno desenvolvimento, é carvalho real. A mudança era, desse modo, o processo pelo qual a potencialidade se transformava em realidade. Mas a espécie carvalho permanecia sempre a 
mesma, através da sucessão: semente, carvalho; semente, carvalho; semente carvalho... Assim concebida, a mudança era regular, conveniente, limitada, previsível. Foi desse modo que Aristóteles procurou conciliar a mudança com a imutabilidade (KILPATRICK, 1978, p.36, itálicos do autor).

Como se nota, a ideia de mudança estivera presente em Aristóteles, porém, cerceada por certos limites, visto que as espécies eram fixas.

Muito tempo de passou até a publicação de A origem das Espécies, cujo escopo significaria uma ruptura com a hipótese de imutabilidade das espécies e traria evidências favoráveis à hipótese evolucionista. A partir de então, qualquer teoria ou filosofia que intencionasse reafirmar o aristotelismo, teria de enfrentar tanto a própria tese darwiniana quanto suas consequentes derivações.

Quanto à pergunta sobre a impossibilidade de a democracia manter-se em marcha sem qualquer elemento permanente, Kilpatrick argumenta que o primeiro passo é a superação do descompasso entre desenvolvimento tecnológico e sua correspondente reflexão ética e epistemológica. Para tanto, em vez da insistência numa espécie de equilíbrio estático provindo da autoridade da tradição, deve-se estabelecer um equilíbrio dinâmico, ao modo do peão que, para se manter de pé, necessita do movimento. Para que essa mudança ocorra, é preciso um mecanismo de adaptação (ibidem, 38-39).

Há, segundo Kilpatrick, um perceptível desejo da sociedade estadunidense em aceitar a tecnologia e sua aplicação à vida cotidiana, porém esse desejo não é aplicável do ponto de vista moral-social, visto que, sobre esse aspecto, essa sociedade não raramente se posiciona de modo retrógrado. Eis, então, a tarefa da educação: auxiliar na conscientização de que a mudança pode ser compreendida e então direcionada para aquilo de que necessita o homem. Nas palavras de Kilpatrick:

Se houvesse alguma coisa como equilíbrio social em movimento, ou estabilidade dinâmica social, ela bem caberia nesse momento e poderia consistir na disposição e habilidade para conservar a visão e a compreensão moral e social à altura das mudanças sociais adotadas. [Nesse sentido,] auxiliar na criação e manutenção desse equilíbrio dinâmico, com o intuito de ajudar o desenvolvimento da visão moral e sua compreensão necessária é o maior dever de um sistema educacional eficiente (KILPATRICK, 1978, p.40).

A ideia de equilíbrio dinâmico social, expressa nesse excerto, é presente no pensamento de Kilpatrick e relaciona-se tanto a um nível mais difuso das relações sociais quanto a um nível mais específico, por exemplo, o das relações pedagógicas escolares, levantado anteriormente neste trabalho quando se tratou do equilíbrio entre a prefixação de conteúdos e os interesses dos estudantes. Em suma, Kilpatrick está inter-relacionando esferas distintas da vida humana, o que 
supõe, ao mesmo tempo, uma preocupação por parte do autor em superar a dicotomia indivíduosociedade e em estabelecer o papel da escola nessa empresa.

\subsubsection{A mudança como paradigma pedagógico}

Para Kilpatrick, o fato de a sociedade estar em plena marcha de mudança não significa a adoção do não-diretivismo pedagógico, mas, apenas, que novas exigências chegam à escola e que mudanças filosóficas e pedagógicas são imprescindíveis.

No sentido mais tradicional, a escola visa à transmissão para os mais jovens de aspectos eleitos da cultura de um grupo. Desde seu surgimento, a escola tem sido apenas um dos espaços que promovem educação; os demais consistem na vivência doméstica e na transmissão não organizada de saberes vinculados à vida diária, como linguagem, deveres domésticos, meios de ganhar a subsistência, disposições e costumes morais e sociais.

Diferentemente de muitos ambientes extraescolares, o espaço escolar possui lugar e tempo preestabelecidos. Porém, em virtude de o espaço extraescolar vincular-se mais diretamente à vida, quando essa muda em algum aspecto, o aspecto educacional é imediatamente modificado; ao passo que, historicamente, a escola formal não acompanhou com a mesma imediaticidade as mudanças do entorno, e, desse modo, passou, gradativamente, a lograr vida própria. Kilpatrick exemplifica:

Encontrou-se, por exemplo, numa tribo indígena americana, perpetuada pelo ensino, uma canção-ritual cujas palavras não eram mais compreendidas, porque pela força das circunstâncias essa tribo tivera de abandonar o seu antigo idioma. Se bem que exemplos desse tipo sejam raros, é frequente observar igual tendência a respeito de muitos pontos do programa escolar (KILPATRICK, 1978, p.42).

Com o passar do tempo, o programa escolar foi, em função da opinião coletiva, tornando-se cada vez mais cristalizado e mais extenso, de modo a exigir maior permanência do educando na escola. E em função do descolamento existente entre o que a coletividade almejava e as necessidades dos aprendizes, seu objetivo também passou a ser o de exigir comportamentos exteriores de aprendizado. Assim, a escola progressivamente tornou-se conservadora e convencional.

Em suma, três são as tendências que concorreram para o descolamento entre a escola e a vida social mais ampla:

primeiro, a inércia do próprio sistema, a tendência natural do formalismo a perpetuar-se dentro de si mesmo, por toda parte; segundo, a influência de 
sinais exteriores de aprendizado, a importância dada a esses sinais, o que tornou, afinal, a matéria meramente convencional; e, terceiro, a possibilidade, que os "conservadores" geralmente têm de usar a escola para fixar na mocidade opiniões e atitudes que julgam de necessidade manter de qualquer forma (ibidem, p.43, itálico e aspas do autor).

Kilpatrick afirma que se educação de fato deve ir além de mera preparação para a vida futura, é preciso ter em mente que o futuro, seguindo a lógica da mudança, não será igual ao presente. Portanto, educar para o presente já se constitui tarefa árdua, quanto mais uma educação para um futuro incerto, que é o principal problema levantado Educação para uma Civilização em Mudança. Antes de tudo, reitera o autor, é preciso adaptar-se à própria mudança.

Com a histórica mudança do trabalho doméstico de subsistência para o trabalho fora do espaço doméstico, a família tem assistido à perda de seu espaço e tempo educativos, já que cada vez mais o lar tem se transformado em local apenas de alimentação e sono. A cooperação existente entre os membros da família e a aprendizagem pelas crianças do labor relativo à subsistência não mais se dão como antes da industrialização. O próprio conteúdo básico da educação doméstica da criança dificilmente trata de como cultivar e preparar o próprio alimento, nem mesmo de como confeccionar as próprias roupas.

Devido ao desenvolvimento industrial e comercial, aos poucos foram desvinculando-se da educação doméstica não apenas processos econômicos naturalmente intrínsecos à vida humana como o cultivo do próprio alimento e a confecção das próprias roupas, mas também a chance de criar disposições na criança de cooperação moral-social e hábitos essenciais da vida do grupo (KILPATRICK, 1978, p.47).

Em suma, a escola tradicional (nos Estados Unidos) desempenhava um papel complementar à educação doméstica. Porém, com a transformação da vida em virtude das transformações que ocorrem no mundo do trabalho, "a ação educativa escolar [de então] tem de mudar, tanto em sua essência quanto em sua gradação, em virtude do enfraquecimento das forças educacionais do lar e da comunidade." (ibidem, p.48).

\subsubsection{O papel da escola diante da atomização ético-política da sociedade}

O desenvolvimento do espírito crítico pressupõe o questionamento de todos os aspectos das instituições até então aceitas e, se necessário, opor-lhes resistência, ainda mais em meio à expansão em progressão geométrica da comunicação e da maior facilidade de se manobrar as massas (ibidem, p.50). 
Kilpatrick afirma que a sociedade industrial, com auxílio da comunicação, tende a caminhar para uma configuração que demanda a especialização de funções no individuo, a agregação dos indivíduos em grupos cada vez mais numerosos e a integração desses grupos para solução dos problemas de mútuo interesse.

No que tange à especialização de funções no indivíduo, é preciso, segundo o autor, que haja um alargamento do sentido da vida para que a pessoa não sucumba à limitação de significados oriundos apenas de sua atividade e de seu círculo profissional. Nesse sentido, é preciso oferecer oportunidades educacionais para que se possa desenvolver os aspectos moraissociais necessários à cooperação.

No que tange às exigências educativas de agregação, é preciso ênfase na valorização vida humana e no desenvolvimento de atividades que não transformem a vida escolar - e consequentemente a vida laboral futura - numa completa prisão. É preciso estabelecer a liberdade de expressão como rotina diária tanto dentro quanto fora da escola, pois, em ambos os espaços, há demandas éticas e sociais envolvidas em função da vida em grupo. Com essa medida, pretende-se a ressignificação do sentimento de impotência vivido pelo indivíduo por se perceber apenas um entre muitos.

Integração não se confunde com agregação. Portanto, é preciso uma mentalidade universal, que, segundo Kilpatrick, implica pensar para além de um partidarismo e um patriotismo cego. Do mesmo modo que seria inviável uma soberania pessoal absoluta, também o seria um país manter-se isolado do restante do mundo em termos sociais, culturais e econômicos. Nesse sentido, de integração, a escola deve visar à formação do cidadão cosmopolita, por meio de uma nova História, uma nova Geografia e uma nova Ciência Social, segundo as quais os fatos abordados não são capciosamente selecionados com vistas a manipular a construção de sentidos dos educandos.

Kilpatrick afirma que para que se possa tornar a democracia uma condição de êxito é preciso praticá-la do ponto de vista comportamental segundo uma teoria educativa à altura da tarefa.

A escola deve mudar de um modo organizacional autocrático para um democrático, o que significa mudar: a) da receptividade passiva à pesquisa responsável; b) do futuro remoto como perspectiva educacional para a vida presente, visto que o presente é o ponto de partida na configuração da emoção, da percepção e do intelecto; c) da concepção de escola como sistema fabril para uma escola em que o poder e a iniciativa advêm de todas as direções e não de uma única fonte centralizada; d) de um planejamento pedagógico estanque e centralizador para uma autodireção eficiente do professor e dos alunos em uma coparticipação de responsabilidades; e) 
de uma escola isolada dos acontecimentos do entorno para uma escola atual e consciente de seu papel dentro do contexto social (KILPATRICK, 1978, p.55-56).

As considerações de Educação para uma Civilização em Mudança ganharão maior enfoque educacional em Remaking the Curriculum, quando Kilpatrick passa a discutir a transformação da escola de modo ainda mais contextual e sistemático, por exemplo, em seu aspecto curricular e em relação à formação inicial de professores. Isso significa que, em relação às obras anteriores, Kilpatrick insere o debate sobre a educação em um universo maior de fatores econômicos, sociais e políticos, dentro dos quais a escola e os educadores de fato estão inseridos (idem, 1936, p.34-36).

A reflexão de Kilpatrick acerca da então dicotômica relação interior-exterior da escola, explicitada em Remaking the Curriculum, contou com um novo e importante elemento: a psicologia meadiana, a qual, em Identidade Pessoal e Civilização, tornar-se-á pilar teórico.

Kilpatrick, gradativamente, passa a assumir que a complexificação da vida em sociedade exige que a educação e a escola sejam pensadas nos mesmos moldes. Dito de outro modo, a complexificação da vida em grupo alterara o equilíbrio da balança pedagógica em cujos pratos contém, cada qual, "conteúdos prefixados" e "interesses das crianças"; ou seja, foi alterado o equilíbrio entre um currículo centrado na criança e um centrado nas demandas sociais, que, nesse caso, deslocou-se em direção à segunda proposta. Em termos darwinianos, a regulação entre organismo e ambiente no que diz respeito a aspectos educacionais e psicológicos ganhou nova configuração, expressa na proposta de Kilpatrick de reconstrução do currículo e no aprofundamento da visão psicológica do autor acerca da sociedade, do indivíduo e da sua interrelação.

Essas são, de fato, propostas de efetivação das questões levantadas em Educação para uma Civilização em Mudança. Diz, Kilpatrick, no segundo capítulo de Reformulando o Currículo:

a mais nova psicologia desenvolve-se de uma biologia mais avançada, a doutrina evolucionista, e o fato da rápida mudança. Ela [, a nova psicologia, também] vê a vida como um processo de interação contínua entre organismo e seu ambiente. [...] Essa concepção de aprendizagem e de pensamento, em contraste com a antiga visão estática [behaviorista], é essencialmente criativa e dinâmica, própria de um mundo plástico e em mudança (KILPATRICK, 1936, p.22, tradução nossa).

Nessa obra, Kilpatrick critica a análise psicológica que reduz o comportamento ao esquema estímulo-resposta, a qual, segundo o autor, impossibilita uma visão mais profunda do ser humano enquanto ser cultural. 
Para que a reorganização cultural dê um passo adiante, é preciso que se efetue um movimento de reformulação metodológica, inclusive sob a mesma justificativa que, anteriormente, fizera a psicologia behaviorista fornecer importantes saberes sobre o comportamento humano e, com isso, contribuir para que o método de ensino se tornasse mais científico.

As leis de aprendizagem de Thorndike são um bom exemplo desses saberes. Porém, essa abordagem psicológica não seguiu na mesma direção na qual seguiram as necessidades educacionais da sociedade. Gradativamente, o behaviorismo foi consolidando a crença na aplicação de métodos padronizados de avaliação (CREMIN, 1964, p.185-187) e a crença em uma educação fundamentada no comportamento humano como resposta a estímulos prefixados do ambiente (KILPATRICK, 1936, p.26). Para Kilpatrick, a escola e os educadores deveriam caminhar em outra direção, de modo a desenvolver a criatividade e o exercício livre do pensamento.

Em suma, Kilpatrick enfatiza que é preciso pensar o ser humano em movimento.

A adoção de uma nova abordagem do fenômeno social, concebida em torno de elementos cuja gênese também é social, conforme propõe a psicologia de Mead, pode ampliar a possibilidade de se enxergar o comportamento humano em sua complexidade e, com isso, dar prosseguimento ao necessário processo de transformação curricular da escola.

O descompasso existente entre a capacidade operacional humana de modificação do ambiente e a capacidade ética de avaliar o quão são benéficas essas mudanças obriga a sociedade e a escola a se repensarem enquanto instituições, conforme Kilpatrick enfatiza no terceiro capítulo de Reformulando o Currículo:

nós já vimos que para lidar com nossa rápida mudança social é preciso reflexão e não mero hábito. E também o quanto a mudança desigual produziu um descompasso perturbador em relação ao nosso balanço cultural, de tal modo que, no momento, precisamos de drásticas mudanças no intuito de colocar a cultura em seu lugar e então formar um todo coeso [composto pela vida material e espiritual]. Essas medidas requerem que nossos cidadãos se vejam desejosos por aprender a criticar e a julgar nossas várias instituições, com o intuito de distinguir entre o que é importante e o que não é (KILPATRICK, 1936, p.34, tradução nossa).

Nesse excerto é possível notar a importância que a crítica às instituições encontra no projeto de educação de Kilpatrick. Uma instituição, para Kilpatrick, significa não apenas um órgão formal que representa os interesses de um grupo, mas formas diversas de organização social, como leis, religiões, partidos políticos, organizações de engajamento social ou ambiental, grupos de intelectuais, grêmios estudantis ou mesmo a própria sociedade. 
3.8.2.1 A mudança como paradigma educacional-escolar: o currículo

Para Dewey, a crítica às instituições significa uma crítica à moral tradicional e a prática de uma moral reflexiva. A distinção entre moral tradicional e moral reflexiva é que "a primeira coloca o padrão e as regras de conduta nos hábitos ancestrais; a segunda apela para a consciência, para a razão e para algum princípio que inclua o pensamento" (DEWEY, 1980, p.201).

Kilpatrick faz referência à noção deweyana de moral reflexiva quando defende que os valores da sociedade não devem se curvar à estaticidade e ao anacronismo, mas, antes, devem colocar-se sob crítica, de forma que se adaptem e estabeleçam uma situação de vida melhor que a anterior.

A educação que tem como paradigma o princípio da mudança exige adaptação, o que sugere um ensino que estimule não a aprendizagem de respostas preestabelecidas, mas métodos de ação eficaz, em situações novas.

Como foi dito, Kilpatrick defende uma educação movida pelos porquês: "A única moral em que podemos crer, para o futuro, é aquela que se baseia num porquê defensivo quando em situações reais da vida social (KILPATRICK, 1978, p.75, itálico do autor)”. No que tange à escola, é tarefa do currículo fazer a crítica à moral tradicional e promover o respeito à liberdade de expressão. E além disso, em função da especialização do trabalho e da vida em torno desse, o currículo deve visar a tornar o interesse social mais forte e mais amplo; em função da massificação cultural, deve visar à estimulação do carácter pessoal; em função da demanda pela vida democrática, deve exigir do educando maior disposição para o bem comum; em função da incerteza do futuro, deve realizar a discussão dos possíveis problemas que poderão surgir em função da situação atual e aprender a tolerar e a discutir eticamente as causas dos males sociais; em função da capacidade de aprender com a experiência alheia, deve proporcionar aquisição dos saberes provenientes da história humana (KILPATRICK, 1978, p.75).

Se a experiência, segundo Dewey, possui um aspecto ativo e outro passivo (TEIXEIRA, 1978, p.13), é preciso que a escola seja o aspecto ativa, que diz respeito à iniciativa criadora, ou seja: a partir de uma queimadura, o que fazer? Pode-se buscar exclusivamente no saber tradicional os primeiros socorros, ou a partir do saber tradicional, modificar a forma de trato do ferimento, de modo a adaptar o ato a uma nova circunstância. E no caso de a pessoa não possuir o saber necessário para prestar os primeiros socorros, existe a possibilidade de compartilhamento de saberes entre os colegas, o que favorecerá o espírito de solidariedade e o interesse de vários educandos em aprender sobre técnicas de primeiros socorros; quando mais 
tarde, esse assunto poderá se tornar pauta "obrigatória" entre os educandos. Nesse sentido, o interesse em aprender não mais se concentra unicamente no indivíduo, mas é compartilhado pelo grupo. Por essa razão, o educador deve, primeiramente, sentir as necessidades do grupo de estudantes e, em seguida, pensar e planejar as experiências de aprendizagem em função dessas necessidades, mesmo sabendo que cada integrante atribuirá um sentido particular à vivência, em função de sua própria experiência pessoal de vida. A experiência compartilhada, que demanda a definição de pautas de interesse comum, é algo fundamental para a vida democrática.

A ampliação das experiências com colegas conhecidos deve, desse modo, expandir-se para relações com grupos maiores e mais afastados, por meio de visitas, correspondência ou intercâmbio. O que o educador deve ter em mente é a importância das relações humanas para a construção de um caráter democrático no estudante (ibidem, p.80).

Outro objetivo de uma experiência educativa realizada em pequenos grupos é a pesquisa sobre a cultura mais ampla em variadas fontes de informações, como livros ou, atualmente, a internet. Se a tarefa é a construção de um castelo, pode-se questionar os educandos sobre como surgiu a arquitetura e qual as bases matemáticas envolvidas no projeto de um castelo. É importante a busca ativa por respostas, visto que esse procedimento "irá fixar-lhes o hábito ${ }^{3}$ de voltar à pesquisa, quando necessário.” (ibidem, p.80).

Quando se trabalha por projetos, a divisão estanque em matérias esvai-se. A construção de um castelo, dentro de um projeto, pode exigir saberes em arte, história, química, física, matemática e tecnologia. Sem contar a linguagem oral, pois os alunos dependeriam de comunicação. E por que não dizer sobre o desenvolvimento do aspecto moral-social do caráter, pois, para se trabalhar em grupo é preciso integrar as diferenças individuais dentro de um objetivo comum, a tomada de decisões, a escolha ou não de um líder, e mesmo o contato e a percepção da moral-social de maneira mais ampla, por exemplo, dentro da História, visto que os castelos surgiram a partir de interesses político-militares de um grupo. Ao longo do desenvolvimento do processo, surgirão as matérias, mas como consequência de uma lógica distingue-se da divisão tradicional (KILPATRICK, 1978, p.80-81).

Trata-se de atividades sinceramente intencionadas ${ }^{4}$. De acordo com esse novo modo de aprender, mais que apreender saberes de outrem e de outros períodos da História, a atividade sinceramente intencionada possibilita o questionamento sobre o sentido dela em si mesma, de

\footnotetext{
${ }^{3}$ Hábito, em Kilpatrick, assume o sentido expresso em A natureza humana e a conduta, de Dewey, a saber: o conjunto de agências positivas que dão forma ao caráter e ao comportamento, de modo a se constituírem como "agentes da observação, memória, previsão e julgamento. [...] Quanto mais numerosos são os hábitos, mais largo se torna o campo de observações e previsões." (DEWEY, 1956, p.141).

${ }^{4}$ Originalmente denominado por Kilpatrick (1918) como wholehearted purposeful activity.
} 
onde surgem a responsabilidade e o sentimento de pertencimento. Trata-se de atividades com finalidade, que possuem como princípio o envolvimento emocional e intelectual e como método o raciocínio das ciências. Esse todo didático que envolve o ambiente educacional tem grande probabilidade de impregnar de forma construtiva a vida externa à escola.

E, embora para Kilpatrick, a mudança tenha se fixado como paradigma, deve-se destacar que na filosofia e na pedagogia do autor também há elementos prefixados, como a própria pedagogia de projeto, o autocontrole pessoal, a responsabilidade, a criticidade, a valorização do interesse, o esforço, a convicção de caráter, a adaptação à constante mudança, o pensamento e ação com bases científicas e a democracia como modo de vida.

Para Kilpatrick, educação é o processo pelo qual se adquire modos de comportamento, como crenças, tendências e modos de reação (ibidem, p.44). Nesse sentido, o conceito de educação abrange aspectos morais, emotivos, psicológicos, intelectuais e sociais. De todo modo, subjaz nesse conceito o conceito deweyano de educação como reconstrução da experiência, visto que, quando

a criança for posta para trabalhar, para dirigir empreendimentos e para resolver problemas que solicitem os seus esforços presentes, [...] o aprendizado e o pensamento do passado são conservados vivos e ativos. Cada novo problema que for encontrado e resolvido ligará o velho ao novo e irá, na razão do trabalho feito, construindo o espírito. Se isto se der continuamente, haverá como resultado o desenvolvimento continuado, e, como vimos antes, contínua reconstrução da experiência. Segundo esse conceito, cada novo exercício significa um valioso passo dado à frente no enriquecimento da experiência (ibidem, p.84, itálico do autor).

A partir desse conceito de educação surge um novo modelo de projeto pedagógico escolar, pensado como sucessão de experiências escolares, que parece melhor convir à sociedade dinâmica e em mudança. Para Kilpatrick, é importante que se prepare as pessoas para um futuro desconhecido, e essa preparação se faz por meio do uso ativo da experiência passada e sua adaptação a situações inéditas (KILPATRICK, 1978, p.84).

Uma observação importante sobre a pedagogia de Kilpatrick é que seu rompimento com a pedagogia tradicional não se dá pela ignorância do devir, mas, antes, por meio de uma pedagogia que se faz no presente e que

consiste em se encarar a vida de modo mais sério ao se tomarem decisões. Viver desse modo, no presente, será ampliá-lo, para que ele contenha o futuro dentro de si. Esse conceito não subordina nem o presente ao futuro, nem o futuro ao presente, mas observa e avalia, num dado momento, como se deverá viver em outro (ibidem, p.85, itálico do autor). 
Muitas das experiências escolares poderão ser previstas e dominadas pelo professor. Por essa razão, devem-se disponibilizar na escola determinadas fontes de informação, ferramentas didáticas que auxiliem a pesquisa ou mesmo planos de ação, desde que o objetivo principal seja o desenvolvimento dos alunos.

O projeto pedagógico escolar deverá valorizar a função educativa do autodirecionamento de forma que, para o educando, o aprender tenha significado e, portanto, seja digno de comprometimento, assim como, por exemplo, ocorre em uma universidade, onde o prazer da pesquisa e da responsabilidade de escolha são necessários se o que se quer é a obtenção de melhores resultados. O ensino e a pesquisa devem gozar de liberdade científica e filosófica para que, sobre esses, deposite-se a confiança da comunidade.

Porém, segundo Kilpatrick, qual o limite entre a iniciativa do educando e a intervenção do professor numa situação pedagógica?

Para o autor, tanto a aprendizagem como o ensino são processos de experimentação, de um tatear a partir de hipóteses. Na escola, inclusive, é válido esse tatear, pois, embora os estudantes tendam a desenvolver interesses comuns em virtude da faixa etária ou do grupo social, é improvável que alguém consiga prever de forma inequívoca seu comportamento, e, então, seja capaz de planejar integralmente todas as intervenções pedagógicas de um curso inteiro. Tendo em vista uma necessária e contínua adequação currículo-estudante, a intervenção pedagógica de que trata Kilpatrick deve ser realizada sempre com a intenção de que os estudantes desenvolvam o pensamento, a capacidade de deliberação e a responsabilidade, o que somente poderá ocorrer se eles praticarem esses comportamentos. Deixar de intervir deve ser um ato deliberado e consciente do professor, pois, são caracteres em formação e, portanto, necessitam de auxílio para seu pleno desenvolvimento. A adequação da intensidade da intervenção pedagógica será feita tendo em vista o maior aprendizado. Em suma, confia-se, avalia-se e, se necessário, reconsidera-se o ensino.

\subsubsection{Princípios didáticos}

O ensino, muitas vezes, carece de sentido tanto para o estudante quanto para o professor, pois, ambos se habituaram a manter-se atentos sobre $o$ que deveriam fazer, mas não sobre o porquê. Essa atitude questionadora é crucial para a proposta pedagógica de Kilpatrick.

Desse modo, e tendo em vista: a) o crescente descompasso entre o desenvolvimento moral-social e o tecnológico, b) o declínio da moral autoritária; c) o futuro incógnito; d) a 
tendência democrática; e) as mudanças sociais decorrentes da industrialização, é preciso que haja uma educação que busque:

a) [uma] moralização inteligente, com o porquê explicativo da conduta [...]; b) métodos de combate a problemas sociais não resolvidos; c) [...] a formação de caracteres morais fortes, firmados em critérios e atitudes sociais liberais. [E continua, Kilpatrick]: para observar essas várias exigências, na sua realidade, será necessário mantê-las bem unidas em nosso pensamento [de educador], e confrontá-las com as situações a que dão origem. Se [, como educadores,] não mantivermos, para esclarecimento recíproco, esse confronto entre a exigência e a situação que a produz, não perceberemos devidamente nem o objetivo, nem o processo da educação nova (KILPATRICK, 1978, p.66).

Do ponto de vista pedagógico, esse excerto referencia o método de projeto, conforme explanado por Kilpatrick no artigo de 1918, cujas ideias básicas são: o confronto do estudante com uma situação problemática dentro ou relacionada ao seu contexto; a reflexão feita pelo estudante sobre a situação e sobre o porquê de se tomar partido diante dela; a iniciativa para buscar informações que auxiliem na solução da situação e para fazer com que essa solução seja levada adiante pela comunidade ou, no mínimo, seja aprendida em forma de comportamento; e a avaliação das intervenções realizadas com a finalidade de se verificar a eficácia da intervenção.

Em Educação para uma Civilização em Mudança, Kilpatrick manteve sua proposta de ensino por projetos, descrita em Método de Projeto; porém, como se nota no excerto, em Educação para uma Civilização em Mudança, o objetivo da proposta pedagógica se apresenta em um nível de contextualização maior, ou seja: de um contexto mais generalizado, como o descrito em Método de Projeto, Kilpatrick passa a abordar o método enfatizando a necessidade de sua contextualização, ou seja, o método de projeto deve ser concebido e direcionado de forma atual pelos educadores.

Em função das transformações materiais e culturais em marcha, a escola à qual se refere Kilpatrick tem a necessidade de ser um local em que se viva, em vez de se configurar apenas como complemento da educação "natural" ministrada pela família ou pela comunidade. Conforme se esvai esse tipo de educação familiar, em virtude da atomização política e social e em virtude da industrialização, a escola tem o dever de se revitalizar pedagogicamente para proporcionar aos aprendizes experiências mais ricas de sentido (KILPATRICK, 1978, p.68).

Aprender é adquirir um modo de comportamento que abrange atitudes emocionais, conhecimentos e habilidades, e para isso é preciso exercício. E para tanto, Kilpatrick considera importante serem levados em consideração três princípios didáticos. 
O primeiro considera que há um abismo qualitativo entre a experiência educacional por meio da vivência real e aquela respectiva experiência que é vivida de maneira quase que totalmente intelectiva. A vivência real proporciona uma interação mais densa e constante entre o indivíduo e o meio, o que resulta em uma maior responsividade da pessoa aos estímulos do meio. A respectiva vivência em nível predominantemente intelectivo tende a se limitar a uma fonte marcadamente mnemônica de significados e sensações. A falta de vivência real do indivíduo tende a levá-lo a um cada vez maior preconceito na sua visão de mundo e no seu julgamento moral.

O segundo princípio remete à psicologia thorndikeana da aprendizagem, a qual, referida por Kilpatrick, diz que

não aprendemos tudo o que praticamos. Só aprendemos o que é bem-sucedido. Digamos mais exatamente: ao tentarmos atingir uma meta desejada, se alguns dos nossos esforços forem bem-sucedidos e outros não, aprendemos a fazer os primeiros e a não fazer os que falharam. Convém notar em como o propósito ou intenção do educando deve ser levado em conta, para determinar se um modo de comportamento será assimilado ao seu caráter como tendência positiva de ação ou se irá sofrer desassimilação, isto é, produzir aversão pela atividade implicada no caso. Assim, se se pretende aprender certo golpe no jogo de tênis, aproveita-se tanto os sucessos como os fracassos (ibidem, p.69, itálicos do autor).

A partir do exemplo do jogo de tênis, Kilpatrick afirma que o sistema nervoso incorpora, gradualmente, os movimentos de êxito na medida em que há a prática frequente. Os movimentos falhos são desassimilados e, então, tendem desaparecer. Se durante uma partida de tênis houver um propósito bastante forte para efetivar o golpe com a raquete, o suficiente para tornarem inconfundíveis tanto o fracasso quanto o êxito - o primeiro seguido de insatisfação, e o segundo, de satisfação -, então a aprendizagem se dará de forma mais efetiva, tanto dos sucessos como dos fracassos, visto que o interesse e o esforço em acertar potencializa negativamente o erro e positivamente o acerto. O movimento aprendido estabelecer-se-á tão firmemente que, no momento exato, o golpe se dará por si mesmo. Desse modo: “o desejo de aprender ensinou. [...] De onde se conclui que o aprendizado segue a direção estabelecida pelo desejo, propósito ou intenção de quem aprende.” (KILPATRICK, 1978, p.69-70, itálico do autor).

No campo social-moral, os dois princípios didáticos atuam de maneira análoga para que os alunos venham a desenvolver qualidades tidas como importantes, como responsabilidade e cooperação, por exemplo. O desenvolvimento de um comportamento responsável e cooperativo se dá de maneira mais eficiente quando os alunos estão envolvidos em uma situação real, para que sejam oferecidas ocasiões sociais para desenvolver as qualidades desejadas - conforme o 
primeiro princípio - e de maneira intencionada e prolongada o suficiente para que o aluno, por meio da percepção e seleção das atitudes bem e mal sucedidas, possa assimilar aquelas que são pertinentes ao grupo. A resposta dos colegas às atitudes do estudante funcionam - conforme o segundo princípio - como elementos mais incisivos para a assimilação/desassimilação de determinados caracteres quando comparada a uma abordagem estritamente argumentativa, em que não há a participação coletiva no ato e ainda mais se essa se der sem qualquer explanação dos porquês (ibidem, p.70).

O terceiro princípio didático refere-se à capacidade de adaptação do conteúdo mental aprendido a situações novas. Quando se tem posse de certo comportamento e surgem situações no ambiente que exigem soluções cuja relação com esse comportamento é estreita, porém não idêntica, ocorre uma adaptação, uma generalização dos princípios internos desse comportamento para que a pessoa resolva a situação em questão. Do ponto de vista dos estímulos do ambiente, quanto maior a semelhança entre os velhos estímulos e os novos, maior a possibilidade da transferência de comportamento, ou seja, da semelhança das respostas em cada um dos ambientes, conforme a psicologia de Thorndike (ibidem, p.71).

Para Kilpatrick, essa relação de transferência comportamental entre ambientes semelhantes estabelecida pelo indivíduo humano é uma das justificativas psicológicas de argumento acerca da semelhança entre a vida escolar e a vida externa à escola como ponto de partida da aprendizagem.

Há, ainda, algumas considerações complementares sobre a aprendizagem que se referem, por sua vez, ao princípio de associação, segundo o qual, quando dois fatos se dão concomitantemente, o pensamento de um tende a evocar mais ou menos o outro na medida do quão íntima, agradável ou desagradável é a conexão entre ambos.

O exemplo que Kilpatrick utiliza para ilustrar esse princípio é o cão de Pavlov, ao qual apresentava-se o aroma de um alimento que o fazia salivar. E enquanto isso se dava, uma campainha soava. Depois de haver repetido esse procedimento por vários dias, fazendo soar sempre a campainha ao oferecer o alimento ao cão, Pavlov, então, passou a somente soar a campainha, sem apresentar o aroma do alimento ao cão, e o som da campainha foi suficiente para que o animal salivasse. Esse fenômeno ficou conhecido como associação, e

é por meio dela que muitas reações emocionais entram em nosso caráter. [...] A cada uma dessas fases ou conexões, disposições emocionais ficam mais ou menos associadas. Muito do que aprendemos se dá, assim, simultaneamente. [...] É a associação que está sempre a construir o nosso caráter, volitivo e emocional (KILPATRICK, 1978, p.72-73, itálico do autor). 
Esses três princípios didáticos: a) de semelhança entre vida escolar e vida externa à escola; b) de sucesso e insucesso e c) de transferência e de associação são algumas das bases sobre as quais Kilpatrick justifica o método de projeto e a questão das aprendizagens concomitantes e associadas, presentes e explicitadas no artigo Método de Projeto.

Vale ressaltar que o princípio de semelhança entre vida intra e extraescolar não se fundamenta em uma concepção de educação reprodutora. Na verdade, trata-se de pensar a escola como um espaço pedagogicamente diretivo, cujas matrizes culturais, que já se encontram postas pelos valores da sociedade, permeiam esse espaço pedagógico pensado. Diante desse fato, e segundo o princípio didático em questão, a escola tem o papel de ressignificar a experiência de seus estudantes, segundo princípios democráticos de conduta e os problemas sociais que permeiam essa escola e a própria democracia.

Há conteúdos comuns entre Educação para uma Civilização em Mudança e Método de Projeto. Por exemplo, as leis de aprendizagem, que são princípios que justificam a semelhança entre ambientes intra e extraescolar como ponto de partida para a aprendizagem, e a própria definição kilpatrickiana de educação pautada na aprendizagem de novos comportamentos.

Em Educação para uma Civilização em Mudança, a argumentação de Kilpatrick gira em torno tanto do elemento da mudança - e seu motor, o pensamento baseado na experimentação - quanto do consequente papel da educação diante desse elemento. Em Método de Projeto, como foi dito, não havia ainda a uma discussão sobre o papel da escola diante de tal elemento. Porém, embora em Método de Projeto Kilpatrick trata enfaticamente de didática, essa discussão é imprescindível para a compreensão das obras posteriores a 1918. E isso é um motivo suficiente para que Método de Projeto seja abordado com maior profundidade neste trabalho.

\subsubsection{Método de Projeto: utilização do ato intencional no processo educativo}

Como dito anteriormente, Método de Projeto é um artigo cujo objetivo é argumentar em favor de uma pedagogia que tenha como fundamento o princípio da ação. Sua publicação fora motivada pela intenção de se superar o impasse da fragmentação teórico-metodológica presente na então educação tradicional, a qual não considerava o comportamento humano em sua totalidade, ou seja, como a resultante de um organismo-em-interação-com-o-ambiente, sendo, esse organismo, dotado de intelecto, emoção, vontades e interesses. 
Embora o pensamento de Kilpatrick fundamente-se em pelo menos cinco pilares teóricos: o darwinismo, o pragmatismo deweyano, a psicologia de Thorndike, a psicologia de George H. Mead e o pragmatismo de William James, a obra Método de Projeto em si contém alguns conceitos importantes e que, como foi dito, estão presentes em obras posteriores, como o conceito deweyano de experiência e os conceitos de ato intencional e de atividade comprometidamente intencional.

O primeiro conceito, o de experiência, foi explanado anteriormente. Os conceitos de ato intencional e de atividade comprometidamente intencionada compõem aquilo que Kilpatrick chama de agir pensado, sendo que o segundo é profundamente explanado em Identidade Pessoal e Civilização a partir das ideias de dever ético e de responsabilidade ${ }^{5}$.

Porém, há elementos em Método de Projeto, especialmente os oriundos da psicologia de Thorndike, que, embora Kilpatrick não os tenha abandonado posteriormente, passaram a ocupar um lugar secundário em suas obras.

\subsubsection{Ato intencional}

Para Dewey, "educação é vida". Mas o que significa afirmar, em termos deweyanos, que educação seja vida, quando é evidente que educação é uma experiência que pode ocorrer concomitantemente a outros processos que compõem a vida?

Primeiramente, educação é vida pois o processo de aprendizagem é inerente à vida humana, em seus aspectos biológico e cultural; e, em segundo lugar, e por consequência, sendo a educação um processo inerente a outras experiências humanas, não pode ser considerada de forma descontínua em relação ao todo da realidade, seja em seu aspecto físico ou simbólico.

Nesse sentido, o conteúdo a que se refere a expressão deweyana “educação é vida” será por Kilpatrick não somente explanado em Método de Projeto, como, em obras posteriores, será tomado como alicerce para a compreensão do surgimento e do desenvolvimento da própria noção de self, cujo processo de formação alicerça-se nas capacidades humanas de aprendizagem e de pensamento. Nesse sentido, a própria possibilidade de existência da vida cultural humana é resultado de um processo educativo histórico. Portanto, para Dewey e para Kilpatrick, educação e vida humana são indissociáveis.

Como foi dito, a partir do conceito de experiência, Dewey desenvolveu tanto seu pensamento epistemológico, quanto pedagógico, psicológico e ético. Kilpatrick, de modo

\footnotetext{
${ }^{5}$ Originalmente denominados por Kilpatrick (1941) como accountability e responsibility, respectivamente.
} 
análogo e muitas vezes subjacente, fundamenta-se nesse conceito para formar sua base argumentativa acerca da aprendizagem, do pensamento e do comportamento.

Em Método de Projeto, Kilpatrick desenvolve sua argumentação a partir de um núcleo conceitual principal, o ato intencional ${ }^{6}$. Para chegar a esse conceito em específico, Kilpatrick, antes de olhar para a educação ou para a aprendizagem, olhou de modo menos distinto para a própria conduta humana e, a partir de então, propôs esse princípio - o ato intencional -, o qual, por sua vez, poderia fundamentar qualquer conduta humana, inclusive a educação.

Em suma, linguística e mesmo filosoficamente é possível compreender não somente o ato intencional, mas a filosofia de Kilpatrick como uma síntese entre os campos do pensamento e da ação. Porém, como foi dito, é preciso ter sempre em mente o sentido ontológico dos termos, relacionados ao conceito primitivo de experiência, sob o risco de o autor ser interpretado segundo uma visão dualista e, portanto, incongruente com sua filosofia.

Os atos nascidos da vontade, ou atos intencionais, são justamente o núcleo da ação humana, diz Kilpatrick (1918, p.04). Agir de maneira minimamente deliberada pressupõe que (h)aja no sujeito um propósito, algo ainda não realizado.

Assim, cada ato intencional é a efetivação dessa projeção intelectivo-emocional, a qual relaciona meios e fins, já que o indivíduo se pôs a arquitetar uma maneira de alcançar seu objetivo. Kilpatrick toma o ato intencional como unidade típica da vida humana e o desenvolve de forma articulada à teoria pedagógica de Dewey e às leis de aprendizagem de Thorndike.

É quando, então, que o autor propõe uma didática que tenha como matriz o ato intencional, de modo a também considerar, em sua complexidade, os ambientes natural e social com os quais os estudantes vão se relacionar. Desse conjunto nasce o método de projetos.

O conceito kilpatrickiano de projeto partilha do caráter teleológico do conceito de ato intencional, sendo que o primeiro refere-se a uma organização pedagógica cujas intenções dos indivíduos nela diretamente envolvidos convergem a um ou mais objetivos comuns, enquanto o segundo refere-se a um elemento da agência individual e não possui necessária intenção pedagógica, embora a aprendizagem também seja um elemento da agência individual e ocorra conjuntamente com ato intencional, de modo mais ou menos intenso. $\mathrm{O}$ ensino por projetos, em si e por sua vez, pode ser pensado como um conjunto de vários atos intencionais contíguos e teleologicamente postos, tanto por parte do docente quanto dos discentes, e o resultado dessa ação social é a aprendizagem.

\footnotetext{
${ }^{6}$ Originalmente designado por Kilpatrick (1918) como purposeful act.
} 
Por agência, entenda-se o curso tomado pelo indivíduo, segundo sua organização interna, cuja finalidade é a intervenção no ambiente ou em si próprio.

Para Kilpatrick, a conduta humana, em seus sentidos axiológico e psicológico, não se circunscreve à esfera unicamente subjetiva, mas é produto do processo indivíduo-sociedade, ou em termos darwinistas, produto da interação organismo-ambiente. Assim, a aprendizagem por projetos visa tanto à cooperação, em sentido psicológico, quanto à cooperação, em sentido ético, sendo, ambas, numa educação democrática, tomadas concomitantemente como meio e fim.

Para aclarar as noções de projeto e de ato intencional, segundo seu sentido em Método de Projeto, Kilpatrick dá o exemplo de uma moça que decidiu usar um vestido, e para tanto o planejou e o confeccionou. Embora a vizinhança a tenha incentivado, o que dominou cada etapa da confecção do vestido e também o que deu um sentido de unidade aos vários passos do trabalho foi a visão do vestido pronto e a intenção de fazê-lo.

Sob a perspectiva de Kilpatrick, a sucessão de atos da garota para confeccionar o vestido pode ser considerada um projeto, cuja unidade da agência fora garantida por um fim específico: o de exibir um vestido feito por ela mesma.

Similar à situação da garota do vestido, outras situações cujo propósito não seja individual, mas coletivo, podem ser também exemplos de projetos. Um grupo de crianças que organiza um jogo, por exemplo, ou mesmo um grupo de alunos que prepara a leitura de uma história para seus colegas.

Os projetos educacionais são caracterizados, segundo o autor, justamente pela presença de uma intenção preponderante compartilhada. Diz Kilpatrick (1918, p.05, tradução nossa):

[...] É nítido que projetos podem apresentar toda a variedade de propósitos presentes na vida. E também é nítido que uma mera descrição superficial dos fatos observáveis poderia não tornar visível o fator essencial, a saber, a presença de um propósito dominante. E é igualmente verdade que pode haver todos os níveis de completude de percepção nos projetos, de acordo com as variações de clareza e convicção que animam os propósitos.

A lógica interna ao método de projetos pensado por Kilpatrick tem sua origem nas reflexões de Dewey sobre o método de reflexão. Consonante a esse autor, Kilpatrick pensa ser preciso ensinar não somente o que pensar, mas também como pensar. Essas ideias foram explanadas mais detalhadamente por Dewey em Democracia e Educação, publicado em 1916, e em Como Pensamos, publicado em 1933.

Nesta obra, Dewey afirma que, para quem ensina ou para quem aprende, o cerne da experiência educativa é o pensar. Além disso, o mesmo método de reflexão que permite a alguém garantir uma asserção discursiva deve, nos mesmos termos, ser capaz de conduzir uma 
experiência educativa. Logo, os pontos essenciais do método de ensino coincidem com os pontos essenciais da reflexão, que são:

Primeiro, que o aluno esteja em uma verdadeira situação de experiência - que haja uma atividade contínua a interessá-lo por si mesma; segundo, que um verdadeiro problema se desenvolva nesta situação como um estímulo para o ato de pensar; terceiro, que ele possua os conhecimentos informativos necessários para agir nessa situação e faça observações necessárias para o mesmo fim; quarto, que lhe ocorram sugestões para a solução e que fique a cargo dele desenvolvê-las de modo bem ordenado; quinto, que tenha oportunidades para pôr em prova suas ideias, aplicando-as, tornando-lhe clara a significação e descobrindo por si próprio o valor delas (DEWEY, 1979b, p.179-180).

Em suma, o método de projetos implica: pensamento lógico, saberes prévios, capacidade efetiva de comunicação e de convivência em função do respeito à personalidade de cada membro do grupo e em função do bem comum, capacidade de projeção e de contínua avaliação do processo, capacidade de autogoverno e de julgamento moral. Por serem, essas, características pessoais necessárias ao exercício da democracia, também devem sê-lo em relação à educação.

\subsubsection{Educação democrática e para a democracia}

Kilpatrick, como dito anteriormente, buscou o elemento nuclear da conduta humana, o ato intencional, e articulando-o ao princípio pedagógico deweyano "educação é vida" e à noção de democracia, concluiu que educar para a democracia e para a vida digna implica fortalecimento do hábito de agir pensadamente ${ }^{7}$. Diz o autor:

Admiramos o homem que é dono de seu destino, que delibera claramente e em função de propósitos de longo alcance, que planeja e executa com cuidado os propósitos então formados. Um homem que habitualmente regula sua vida tomando como referência os objetivos de uma vida social digna ao mesmo tempo em que exige eficiência prática e responsabilidade moral, tal como aquele que apresenta o ideal democrático de cidadania.

$[\ldots]$

Se o ato intencional é em realidade a unidade típica da vida digna, então se segue que embasar educação sobre ato intencional é exatamente identificar o processo de educação com vida digna ela mesma. As duas então se tornam a mesma (KILPATRICK, 1918, p.06, tradução nossa).

Para Kilpatrick, a vida digna não se antagoniza com a vida democrática e em ambas está implícita uma noção de liberdade que é contrária à condição humana de subalternidade. Dentro

\footnotetext{
${ }^{7}$ Do original, em inglês: act on thinking.
} 
ou fora de ambientes intencionalmente educacionais, num regime de subalternidade, a ausência de atos ou atividades sinceramente intencionais potencializa a falta de sentido das próprias ações e também a falta do exercício de responsabilizar-se por essas. A partir do instante em que a educação toma como ponto de partida o ato intencional, está tomando como base metodológica a ideia de projeto e como base ética e política a vida democrática, a qual implica liberdade, responsabilidade e dever ético.

Metodologicamente, uma educação segundo esses critérios deve considerar que se a vida digna consiste em atos intencionais livres e responsáveis, é importante que a formação do indivíduo ocorra justamente por meio do exercício deliberativo orientado diante dos vários fatores trazidos pela vida em sociedade e sob regime de liberdade e responsabilidade (ibidem, p.07).

\subsubsection{Tipos de projeto}

Kilpatrick classificou os projetos em quatro tipos: a) Tipo I, cujo propósito é efetivar alguma ideia ou plano em forma externa, como a construção de um barco, a escrita de uma carta, a apresentação de um jogo; b) Tipo II, cujo propósito é a apreciação estética, como ouvir uma história, uma sinfonia ou apreciar uma pintura; c) Tipo III, cujo propósito é a resolução de alguma dificuldade intelectual, como o equacionamento do movimento de um corpo ou a solução de um enigma; d) Tipo IV, cujo propósito é a obtenção de um certo nível de habilidade em alguma tarefa, como aprender um novo idioma ou novos acordes no piano.

Kilpatrick deixou claro que é possível que um projeto Tipo I possa ser utilizado como meio para o desenvolvimento de um projeto de outro tipo. No entanto, é possível estabelecer alguns procedimentos para cada tipo de projeto.

Para o projeto Tipo I, são sugeridos os seguintes passos: proposição, planejamento, execução e avaliação. Todos os passos devem ser acompanhados pelo professor para que seja exigido das crianças aquilo que lhes é possível e não resulte em uma frustração desnecessária. É preciso clareza em definir objetivos e, na avaliação final, é preciso considerar até que ponto esses objetivos foram atingidos e o que pode ser feito para melhorar o processo.

Para o Tipo II, Kilpatrick não elencou passos a serem sugeridos.

O projeto Tipo III é o mais bem conhecido, cujos passos são descritos por Dewey no livro Como pensamos, particularmente no sexto capítulo. 
Em suma, nesse capítulo, Dewey busca demonstrar que "a função do pensamento reflexivo é [...] transformar uma situação de obscuridade, dúvida, conflito, distúrbio de algum gênero, numa situação clara, coerente, assentada, harmoniosa.” (DEWEY, 1979a, p.105-106).

Dewey tomou como matriz da reflexão a experiência vivenciada em forma de situações - tal como Kilpatrick a concebe no método de projetos - e conclui:

não há melhor modo de se saber se se realizou uma genuína inferência do que perguntar se terminou pela substituição de uma situação embaraçosa, discordante, por uma situação clara, ordenada, satisfatória. Um ato parcial e ineficaz de pensar acaba em conclusões formalmente corretas, mas que absolutamente não influem no que é imediata e pessoalmente experimentado (ibidem, p.106).

É notória a ênfase dada pelos projetos Tipo III ao esforço intelectual, sendo que para os projetos Tipo IV podem ser seguidos os mesmos passos que os utilizados no Tipo 1.

Para que o método de projeto seja efetivo, Kilpatrick deixa claro que, além de tudo, é preciso a adequação necessária do ambiente escolar em relação ao mobiliário, aos equipamentos, à arquitetura, ao projeto pedagógico e ao currículo, aos planos de seriação e promoção e, principalmente, à atitude do educador em perguntar para si sobre o porquê de sua prática. 


\section{A MUDANÇA COMO PRINCÍPIO PSICOLÓGICO}

Em Método de Projeto, Kilpatrick conceitua o ato intencional como unidade típica da vida. Ao conceito de ato intencional correlaciona-se o conceito kilpatrickiano de educação, a saber, o processo pelo qual se adquire modos de comportamento (KILPATRICK, 1978, p.44). Correlacionar aprendizagem a desenvolvimento comportamental é algo profundamente complexo, pois abrange os aspectos: a) ontológico - a partir do conceito deweyano de experiência -; b) biológico - a partir do conceito darwiniano de evolução -; c) ético e político - a partir da visão de democracia e do conceito de moral reflexiva deweyanos - e d) psicológico - a partir dos conceitos deweyanos de hábito e de interesse, do conceito thorndikeano de arco reflexo e do conceito meadiano de self.

Todos esses aspectos estão submetidos ao princípio da mudança, originário da teoria darwiniana da evolução e sobre o qual se apoia a obra de Kilpatrick.

Este item, A mudança como princípio psicológico, visa a explicitar especificamente os princípios psicológicos a partir dos quais Kilpatrick elaborou sua filosofia da educação, os quais incluem as leis e princípios thorndikeanos da aprendizagem e o conceito meadiano de self.

\subsection{A PSICOLOGIA DE THORNDIKE E A PEDAGOGIA PROPOSTA POR KILPATRICK}

$\mathrm{O}$ ato intencional, além de ser uma unidade da conduta, tem sua base na psicologia de Edward Lee Thorndike, em particular na obra Psicologia Educacional, segundo a qual qualquer ato do comportamento humano ou animal consiste em uma resposta do organismo a uma situação existente, resposta, essa, que se dá em função de conexões no sistema nervoso.

Por organismo, entende-se, a partir da obra, o de animais não humanos, que foram os primeiros "objetos" de experiências em laboratório. Entretanto, Thorndike afirma que os princípios extraídos de seus experimentos podem igualmente ser utilizados como base para a compreensão do comportamento humano, pois, embora as reações no homem sejam de longe mais complexas que as nos animais "inferiores", a explanação das reações destes pode revelar por analogia algumas "forças" que regem a aprendizagem no homem. Desse modo, as leis de aprendizagem levantadas por Thorndike e referenciadas por Kilpatrick são aplicáveis, segundo esses autores, ao estudo do comportamento humano (THORNDIKE, 1913b, p.16).

Fundamentado em Thorndike, Kilpatrick afirma que certos feixes de conexões nervosas estão naturalmente na espécie humana desde o nascimento, como, por exemplo, os que permitem que o bebê chore quando está com fome. Outros feixes de conexões são adquiridos 
ou modificados, quando, por exemplo, a criança expressa verbalmente que está com fome. $\mathrm{O}$ processo de aquisição ou modificação desses feixes de conexões é chamado de aprendizagem (KILPATRICK, 1918, p.07).

Thorndike, a partir de seus trabalhos, fez certas generalizações de como a aprendizagem se efetua. Generalizações que ficaram conhecidas como leis da aprendizagem. Em A psicologia da aprendizagem, um volume da obra Psicologia Educacional, o autor apresentou as três leis primárias da aprendizagem e os cinco princípios e leis secundários.

As leis primárias são: Lei da Prontidão, Lei do Efeito e Lei do Exercício.

Os cinco princípios e leis secundários são: Princípio da Múltipla Resposta, Princípio da Atitude (ou Set), Princípio da Associação Transferida, Lei da Atividade Parcial e Lei da Assimilação (THORNDIKE, 1913b, p.01-16).

Kilpatrick concentrou-se nas três leis primárias e no Princípio da Atitude, porém não deixou de indicar o estudo das demais leis e princípios para que se tenha uma explanação mais completa do que ocorre na aprendizagem.

\subsubsection{Leis primárias e princípios e leis secundários da aprendizagem}

A primeira lei primária é a Lei da Prontidão, que afirma haver diferentes níveis de prontidão para as conexões neurais, sendo que para determinadas condições do meio há conexões mais prontas para agir e outras menos. Kilpatrick, ao exemplificar essa lei, retoma o exemplo já citado: se a criança está com fome, as conexões relacionadas às manifestações de alegria e as relacionadas à feição fechada não possuem o mesmo nível de prontidão, visto que, no caso, as conexões relacionadas à feição fechada estão mais propensas a entrar em ação. Diz, Kilpatrick:

\footnotetext{
Quando uma conexão está pronta para agir, agir gera satisfação e não agir gera aborrecimento. Quando uma conexão não está pronta para agir, agir gera aborrecimento e não agir gera satisfação (KILPATRICK, 1918, p.07, grifos do autor, tradução nossa).
}

A segunda lei primária é a Lei do Efeito, segundo a qual "[...] quando uma conexão modificável age, ela é fortificada ou enfraquecida de acordo com a satisfação ou o aborrecimento que dela resulta (ibidem, p.08, tradução nossa).

A terceira lei primária, a Lei do Exercício, compreende a Lei de Uso e Desuso, que sumariamente afirma: 
Quando uma conexão modificável é feita entre uma situação e uma resposta, a força dessa conexão é aumentada, [caso] os outros fatores permaneçam iguais. [...] Quando uma conexão entre situação e resposta não é feita durante um intervalo de tempo, a força dessa conexão é diminuída (THORNDIKE, 1913b, p.02-04, tradução nossa).

O Princípio da Múltipla Resposta diz, resumidamente, que a uma dada situação, o indivíduo pode dar várias respostas, as quais vão sendo selecionadas e reforçadas suas respectivas conexões (THORNDIKE, 1913b, p.12).

O Princípio da Atitude ou Set afirma que as respostas dadas por um indivíduo são o produto da ação de vários fatores internos a este que se manifestam no momento do atoresposta. Assim, para situações semelhantes, o indivíduo poderá dar diferentes respostas justamente em função de seu estado íntimo (set). "Qualquer processo de aprendizagem é condicionado pela predisposição (set) da mente no momento (ibidem, p.13, tradução nossa).

Kilpatrick dá uma atenção especial a esse princípio, principalmente em Método de Projeto.

O Princípio da Associação Transferida diz que o indivíduo é capaz de associar uma sequência de situações que conduzem ao objeto que lhe traz satisfação mesmo que não haja qualquer semelhança entre a situação atual e situação alvo.

A Lei da Atividade Parcial afirma que em uma situação em que há exposição do indivíduo, há fatores que são preponderantes a outros, o que conduz a respostas distintas em função da preponderância de um fator ou de outro.

A Lei da Assimilação diz que as respostas às situações são o resultado das conexões neurais originais mais as conexões adquiridas pelo indivíduo. Ou seja, para situações semelhantes, o mesmo indivíduo dará respostas inéditas na medida em que acumula experiência.

Vale ressaltar que quando há uma resposta do indivíduo a uma situação, essa resposta implica não somente uma conexão, mas um feixe de conexões, dos quais alguns serão fortalecidos, outros enfraquecidos (ibidem, p.03).

Kilpatrick apropriou-se das leis e princípios levantados por Thorndike e os utilizou como base para corroborar a tese de que o homem é naturalmente inclinado à ação, tendo em vista que a contínua busca por dar respostas a determinadas situações é, como mostrou Thorndike, uma demanda natural do indivíduo. Nas palavras de Kilpatrick (1918, p.08, tradução nossa):

Esses fatos [, leis e princípios levantados por Thorndike,] se encaixam bem com a generalização de que forças e capacidades mentais do homem estão em conexão com a contínua obtenção de fins demandados pela vida do organismo. 
[Por exemplo,] a capacidade de predispor-se - set - significa, no caso do homem, a capacidade de persistência e ação dirigida.

Dessa forma, Kilpatrick vai ao encontro de um dos princípios darwinianos que também é presente no pensamento pragmatista, o qual afirma que os organismos vivos tendem naturalmente à sua preservação quando na interação com o ambiente. Em termos psicológicos e pedagógicos, diz-se que a pessoa aprendeu como forma de resposta a um estímulo, o que, em termos biológicos, significa que o organismo se adaptou ao meio para auto-preservar-se.

A relação identitária entre os termos adaptação e aprendizagem foi anteriormente explanada neste trabalho, sendo que ambos os conceitos, cada qual dentro de um campo teórico, têm um princípio em comum: a natureza ativa do organismo.

O significado teleológico dessa natureza ativa se dá em função do movimento de autopreservação feito pelo organismo, movimento, esse, exclusivo do campo da vida, conforme afirma Anísio Teixeira (1978, p.13).

Uma das diferenças entre as concepções tradicional e renovada de aprendizagem, relacionadas à natureza teleológica da aprendizagem, é a de que na concepção tradicional, os fins da ação estão postos e resta, então, ao professor e ao aluno alcançá-los. Esse modo de conceber a aprendizagem acaba por se manter distante da natureza biológica e psicológica do ser humano. E o resultado desse distanciamento é o descompasso entre as expectativas de resposta colocadas sobre o indivíduo e as que de fato ocorrem. É como se ao professor exigisse prever todas as perguntas que os alunos farão durante uma aula. A impossibilidade de isso ocorrer explicita, que, de fato, o caráter teleológico da natureza ativa humana não implica uma predeterminada adaptação ou aprendizagem.

O descompasso entre as acepções tradicional e renovada, visto sob a perspectiva das leis da aprendizagem, poderia ser elucidado da seguinte forma: a todo instante o indivíduo é compelido a dar respostas aos inúmeros estímulos que surgem. De acordo com essas respostas, outros estímulos podem ou não ser gerados, como, por exemplo, em uma situação em que o professor prepara uma aula pressupondo exatamente quais as perguntas que serão feitas por seus os alunos. Em linhas gerais, é possível "prevê-las". Porém, rigorosamente, jamais o professor seria capaz iniciar sua aula com todas as respostas e os eventos previamente concebidos, pois o curso da aula é dado na e a partir da relação entre todos os indivíduos envolvidos, inclusive na relação desses com o ambiente.

Mas, em função desse argumento, poderia o método de projeto de Kilpatrick ser considerado uma forma não-diretiva de ensino, já que não há a fixação a priori de conteúdo? 
Em termos educacionais, uma das consequências da negação da existência de fins absolutos é a correspondente negação do currículo escolar elaborado absolutamente a priori. Porém, isso não nega a necessidade de se pensar previamente e sob certo limite sobre o conteúdo a ser abordado pelo trabalhado pedagógico, pois, do contrário, seria o mesmo que negar o princípio elementar do método de projetos, o ato intencional, e, portanto, entrar em contradição.

A educação para Kilpatrick é um processo teleológico, o que não significa supervalorização do conteúdo a ser ensinado como se fosse um fim em si mesmo. É preciso ter em mente que para o autor o estabelecimento de conteúdo, independentemente do método empregado, obedecerá a um fim que corresponde, em última instância, a um contexto irrevogavelmente mutável, e, portanto, formará um cidadão que daquele momento em diante está a adentrar um futuro incerto. Nesse sentido, Kilpatrick é enfático quanto à negação de conteúdos prefixados, sob a justificativa de se estar produzindo um currículo obsoleto.

A negação da existência de fins absolutos corrobora também o pressuposto darwiniano de que o único fim é a evolução, a qual segue para um rumo que está fora do alcance do conhecimento do homem. Essa premissa, assim como a discussão sobre os fins a serem elencados pelo currículo escolar, está fortemente presente em Educação para uma Civilização em Mudança, especificamente quando o autor trata da constante mudança das relações sociais e da cultura e as consequentes demandas para a educação.

\subsubsection{Leis e princípios de aprendizagem e o ato intencional}

Sobre a aplicação das leis de aprendizagem no método de projeto, Kilpatrick dá o exemplo de um menino que decidiu fazer, pela primeira vez, uma pipa.

Se, mesmo após haver iniciado a tarefa, ele não obteve qualquer sucesso, sua proposta inicial ainda permanece. A intenção de fazer a pipa é a resultante de seu set que, consciente e voluntariamente, aponta para um fim. Como disposição interna, o set é o que sustenta o garoto diante das dificuldades do processo e lhe move internamente os recursos cognitivos necessários para a tarefa.

Os parciais sucessos relacionados com as fases da confecção da pipa lhe proporcionam satisfação, o que, segundo a Lei do Efeito, implica o fortalecimento de certos feixes de conexões neurais. Desse modo, conclui Kilpatrick,

o propósito, então, proporciona a motivação, torna disponíveis recursos internos, guia o processo ao seu fim preconcebido e, por meio desse sucesso satisfatório, fixa na mente do garoto e em seu caráter os passos bem-sucedidos como parte e parcela de um todo. [É dessa maneira que] o ato intencional se 
embasa nas leis de aprendizagem (KILPATRICK, 1918, p.09, tradução nossa).

Porém, para Kilpatrick, a aprendizagem não corresponde apenas a respostas desejadas e perceptíveis externamente, mas inclui todas as respostas internas da pessoa. Para evidenciar essa concepção, o autor, dessa vez, a exemplifica hipoteticamente por meio da história de dois garotos, por motivos diferentes, confeccionaram pipas idênticas. Um dos deles tinha o desejo de fazê-lo, enquanto o outro a quem a tarefa lhe havia sido imposta acabou por fazê-la contra sua vontade.

Cada passo dado por cada um dos garotos é chamado pelas leis de aprendizagem de respostas primárias. Simultaneamente às respostas primárias, há outras respostas que não se dão externamente, mas internamente. Essas, por sua vez, podem ser divididas em respostas associadas e respostas concomitantes. Apesar da terminologia, por respostas associadas entendem-se as emoções e as ideias da pessoa que estão diretamente relacionadas às respostas primárias, ao ambiente e à intenção do garoto de fazer a pipa, como cortar e colar o papel. Por respostas concomitantes entendem-se aquelas que são menos específicas em relação à atividade desenvolvida, que resultam em atitudes generalizadas como, por exemplo, autoestima e responsabilidade.

Há de se considerar que o set condiciona o processo de aprendizagem. O set do garoto que faz a atividade motivado, ao passar por um estado de satisfação em função do sucesso, fixa rápida e fortemente certas conexões, trazidas por esse sucesso, diferentemente do que ocorre no caso da atividade desenvolvida sob coerção, em que pode haver dois diferentes sets em operação: um que age a favor do fazer a pipa, e outro que age contrariamente a esse objetivo (KILPATRICK, 1918, p.10).

No caso de sets opostos, ainda que haja um set favorável à atividade, provavelmente ocorrerá um conflito interno em relação ao significado do sucesso, pois um destruirá a parcela de satisfação do outro, o que dificulta a aprendizagem. O contrário ocorre com o indivíduo sinceramente motivado, cuja maioria dos passos dados, mesmo aqueles que são puramente mecânicos, são conjunta e justificadamente postos por uma consciência que tem a percepção do todo e o processo acaba por favorecer a aprendizagem positiva (ibidem, p.10).

Além disso, no caso das respostas associadas, a motivação sincera permitirá tornar muito mais disponíveis os recursos internos da pessoa para organizar o pensamento de maneira que cada passo seja inferencialmente conectado a outras experiências correlatas ou mesmo pertinentes. Então, várias possibilidades de execução e de significado poderão surgir para esse garoto enquanto estiver dominado por um forte propósito, ao contrário do que ocorre com o 
garoto que não tem o mesmo interesse, cujo set, ainda que permaneça ativo, influenciará negativamente as respostas internas, que serão poucas, assim como os elementos de satisfação que as fixariam.

\subsubsection{Ato intencional e a escola}

Em relação à escola, Kilpatrick levanta a mesma questão: até que ponto a escola não tem deixado de lado a aprendizagem de fato para dar atenção apenas às respostas primárias?

A riqueza da vida está em refletir sobre o próximo passo, na busca por mais vida. Se na realização de uma atividade, mesmo a mais simples, durante o processo não for produzido no indivíduo um auto-desejo de prosseguir e acima de tudo de auto aprimorar-se, a atividade não possuirá real valor educativo (KILPATRICK, 1918, p.12).

Vale salientar que Kilpatrick, em Método de Projeto, afirma que ao propor uma pedagogia que se apoia no ato intencional,

não quer dizer que toda intenção seja boa, nem que a criança seja um juiz adequado entre os propósitos, nem que ela nunca seja forçada a agir contra um propósito nutrido por ela. Não se deve contemplar nenhum esquema de subordinação do professor ou da escola ao capricho infantil (1918, p.12, tradução nossa).

Ou seja, Kilpatrick entende que embora haja conflitos entre as demandas sociais e os interesses da criança, é uma questão importante e pontual saber o quão pertinente é para a aprendizagem do grupo cada um dos interesses individuais. Como foi dito num item anterior, o termômetro para o professor saber o quão pertinente é sua ação sobre o grupo é o nível de desenvolvimento no grupo do espírito democrático e da autonomia intelectual e moral.

\subsubsection{Ato intencional e a educação moral em Método de Projeto}

Em Kilpatrick, a educação moral se vale dos princípios que regem a atividade intencionada. Sobre a questão, diz textualmente: "o caráter moral é principalmente um caso de relações sociais compartilhadas, a disposição para determinar a conduta e as atitudes de alguém com referência ao bem-estar do grupo.” (ibidem, p.13, tradução nossa).

Do ponto de vista psicológico, educação moral

[...] significa a construção de conexões estímulo-resposta tais que quando certas ideias são apresentadas como estímulos, certas respostas aprovadas se seguirão. [...] [É preciso] que as crianças adquiram um considerável estoque de ideias para servir como estímulos para conduta, que elas desenvolvam bom 
julgamento pela seleção da ideia apropriada em um dado caso, e que elas tenham fortemente construídas cada conexão de resposta que resultará - tão inevitavelmente quanto possível - em uma conduta apropriada uma vez que a ideia apropriada seja escolhida (KILPATRICK, 1918, p.13, tradução nossa).

Em se tratando da escola, é proposto que se construa certo corpo de ideias e de habilidades de julgamento em situações morais para que, com isso, haja o desenvolvimento de conexões de resposta apropriadas. Para adquirir esses elementos, o autor sugere veemente a vivência em um meio social em que, sob uma supervisão competente, a criança seja levada a lidar com uma grande variedade de situações que suscitem a ação tanto individual quanto coletiva e, não raro, haja conflitos interpessoais.

Numa situação de aprendizagem, a função do professor é guiar os alunos num processo de valoração diante das situações vivenciadas na medida em que esses passam a cada vez mais discriminar entre certo e errado. Para que os alunos ascendam a um nível de autonomia concernente à vida democrática, o professor deverá ir gradativamente ausentando-se das deliberações desses.

As situações, fonte de ideias e habilidades, são, do ponto de vista neurológico, fontes de conexões estímulo-resposta, e é por meio do contínuo compartilhamento de interesses e propósitos que a escola fornece condições para a formação do hábito pessoal de solidariedade. Há nesse processo a participação da Lei do efeito: "se a criança está a estabelecer hábitos de ação, a satisfação deve acompanhar o feito, e o desprazer, a falha." (ibidem, p.13-14, tradução nossa).

Um fator de grande influência na formação do caráter é a aprovação ou desaprovação das pessoas ao redor, pois, da mesma maneira que ocorreria sob um regime de coerção, ao contrariar um set, é possível que não se formem as conexões desejadas, e então o comportamento requerido será apenas aparente.

Porém, se o professor colocar os alunos na posição de decidirem juntos o que é certo, a probabilidade de se formar um set contrário é diminuída, embora ainda haja a possibilidade de isso ocorrer. É preciso, acima de tudo, enfatizar a importância da participação do professor para a formação das conexões pretendidas.

Se entre os alunos houver pontos de vista diferentes em relação a algum assunto, vários alunos provavelmente agirão sob sets internos opostos. Porém, a oposição de sets tende a ser dissolvida quando o indivíduo compreende o motivo pelo qual houve discordância.

A discordância, nesse sentido, é plausível, já que uma concordância apenas aparente (não no sentido de dissimulação) não formaria um caráter convicto e não incitaria a uma nova discussão. Esse é um dos motivos pelos quais o método de projeto une democracia e educação. 
A busca pessoal por objetivos é um hábito desejável. Para isso, é preciso que se construa nas escolas determinados ideais - que são ideias unidas a "tendências de ação" - e o professor seja o responsável pelos resultados. Diz Kilpatrick (1918, p.14, tradução nossa):

Os alunos trabalhando sob suas orientações devem, por meio das experiências sociais encontradas, construir ideais necessários à vida social aprovada. $\mathrm{O}$ regime de atividades intencionais oferece[rá] então uma mais ampla variedade de experiências morais mais tipicamente próximas da vida mesma.

Esse excerto vai ao encontro da afirmação de Kilpatrick de que "a democracia sobretudo representa vida moral" (KILPATRICK, 1978, p.28). Esse caráter moral da democracia e consequentemente da educação democrática é citado novamente pelo autor em 1951, na obra Filosofia da Educação, quando trata da necessidade de se elaborar um mapa de valores para compor o currículo: "o mapa educacional de valores [...] é o agregado daquilo que a educação significa 'honesta' e 'profundamente' e, especialmente, do que ela está conduzindo, o todo que a educação deve buscar realizar com os alunos (idem, 1951, p.333, aspas do autor, tradução nossa).

Sobre a questão da maturação psicológica da capacidade de escolha, é preciso considerar que a criança deixará de responder irrefletidamente ao ambiente e passará a entreter propósitos à medida que acumula e organiza experiências. À (con)formação de um set são naturalmente incorporados os retornos positivo e negativo do ambiente, assim como os próprios atos realizados no processo. Mais tarde, essas associações aparecerão como "sugestão" e, ainda mais adiante, como escolha consciente de passos na busca de propósitos formados deliberadamente, ou seja, a busca de meios para a realização de um fim. Esse processo de maturação deliberativa faz com que se crie a atitude de liderança (idem, 1918, p.14-15).

Uma habilidade adquirida como fim pode ser utilizada como meio para novos propósitos. Habilidades ou ideias que surgem como meios podem inspirar diversos e diferentes fins, assim como inspirar qualitativamente o interesse na busca por novos assuntos, ou quantitativamente, em forma de resistência - ou esforço, em Dewey - por meio da qual um set tende a se manter ativo.

O interesse, assim como a aprendizagem, poderá surgir de uma situação de coerção, embora a satisfação não tenha a mesma intensidade em função do conflito que há entre os dois sets opostos, o de origem externa, voltado à efetivação imediata e o de origem interna, contrário e voltado para outro tipo de atividade. Porém, não é raro que uma preferência preexistente ganhe força e atue de forma responsiva ao estímulo do ambiente e, nesse caso, estabeleça as respectivas conexões. De todo modo, é importante que se perceba, nesse caso, a diferença entre 
autoritarismo e ação pedagógica intencionada: o primeiro é tido como exceção; a segunda, como pedagogicamente louvável.

\subsection{CRÍTICA AO BEHAVIORISMO}

Embora Kilpatrick tenha se dedicado por quase uma década aos estudos e à aplicação das leis de aprendizagem de Thorndike, a partir do final da década de 1920, ele passa a questionar essa psicologia.

Como dito anteriormente, Kilpatrick não negou a contribuição das psicologias comportamentalistas para a educação. Porém, em certo momento afirmou que um estudo atomizado do comportamento não possibilitaria uma melhor compreensão das relações humanas. E, além disso, para o autor, há outro problema que surgiu a partir do desenvolvimento do behaviorismo, a saber: a ênfase em educar por meio de treinamento e avaliar o ensino por meio de testes padronizados.

Uma das motivações de Kilpatrick ao escrever Identidade pessoal foi a de trazer para o debate da educação uma visão mais social de psicologia, o que para o autor, significaria ir ao encontro de uma psicologia que tivesse por base uma abordagem inclusiva da interação organismo-ambiente e não uma abordagem que priorizasse apenas um dos polos, que, no caso do behaviorismo, significa priorizar as reações do indivíduo.

Segundo Kilpatrick, era preciso, também, ir para além do estudo circunscrito a fenômenos mensuráveis, nas palavras do autor:

[ir além da forma com a qual] a psicologia mecanicista tem agido, com ênfase em estatísticas e testes mensuráveis. [...] [E como resultado:] gêneros mecânicos de ensino e supervisão têm florescido. A personalidade, seja do professor ou do aluno, é desprezada. Métodos ditatoriais [que] fogem dos procedimentos democráticos. A moralidade tendendo a ser reduzida a itens de um código formal. As filas e o enquadramento pessoal são encorajados. [Nas escolas,] o julgamento da pessoa é, em todo lugar, feito com o intuito de adequação a padrões preconcebidos antigos (KILPATRICK, 1941, p.102, tradução nossa).

Para o autor, uma psicologia embasada na abordagem organismo-em-interação-comseu-ambiente poderia superar os reducionismos em questão e, de fato, contribuir para a educação integral das pessoas. Para tanto, a psicologia deveria refletir uma educação que assumisse algumas características, como: a) o tratamento dos alunos de modo a considerar suas potencialidades e, com isso, eliminar humilhações; b) o aproveitamento dos benefícios da apreciação da arte em geral e da literatura como possibilidade de reflexão ética e estética e de 
sensibilização perceptiva e emocional; c) o trato com a pessoa em sentido pleno, admitindo sua individualidade e, portanto, reconhecendo sua personalidade.

Kilpatrick considera que desde seu surgimento em 1860, com Fechner, até a década de 1920, a psicologia de fato seguiu seu intuito original, que era o de se consolidar como ciência. Porém, a partir de meados da década de 1930, muitos psicólogos deixaram de dar ênfase ao ser humano por completo e, presos ao dualismo cartesiano, mantiveram sua ênfase no comportamento mecanicamente concebido e desconsideram o papel da mente na instauração de propósitos para o comportamento.

Para Kilpatrick, essa psicologia padecia em função de dois problemas: primeiro, porque perdera sua relação com a vida comportamental humana real; e segundo, por haver perdido seu caráter científico.

Kilpatrick (1941, p.87) exemplifica esse distanciamento da vida real humana a partir de um trecho, já citado, de Psicologia Educacional em que Thorndike trata do processo psicológico que tem como resultado a satisfação. Eis o trecho: “[A] operação bem-sucedida [no organismo] pode, de fato, ser satisfatoriamente definida [...] como uma característica do comportamento interno dos neurônios.” (THORNDIKE, 1913a, p.125, tradução nossa).

Kilpatrick afirma que, em certa medida, Thorndike, na obra em questão, considerou o organismo humano como um todo, porém, ao fundamentar sua Lei do Efeito, reduziu-o a um processo interno de "comportamento de neurônios", desprezando, assim, a abordagem thorndikeana inicial do comportamento, tanto quanto a existência, no ser humano, de propósitos. Aparentemente, diz Kilpatrick, há um “esforço” por parte dos psicólogos para reduzir o pensamento a uma forma não pensante.

Outro exemplo são os escritos de John B. Watson, em Behavior, quando esse autor, segundo Kilpatrick, "reduz o pensamento a movimentos de fala inaudíveis, [sendo que] esses, por sua vez, são considerados [por Watson] como nada além de condicionamentos inconscientes.” (WATSON, 1914, p.351 apud KILPATRICK, 1941, p.87).

Há também os escritos de Weiss, os quais, segundo Kilpatrick, confirmam o desejo de Weiss de fazer da psicologia mera questão de química e física, onde pensamento significa nada além de movimentos e mudanças do padrão de agrupamentos de prótons e elétrons (WEISS, 1929, p.54 apud KILPATRICK, 1941, p.87, tradução nossa).

Além de desconsiderar como horizonte a vida humana, para Kilpatrick, a psicologia deixou de ser científica, pois

a essência do método científico é: começar com o material bruto da experiência comum a nós todos, estudá-lo cuidadosamente de modo mais 
adequado possível, e então retornar a nós, ainda tendo em vista o material bruto, e sobre esse material contar-nos mais do que sabíamos anteriormente, mais sobre como fundamentalmente se comporta, e então [descrevê-lo] mais e melhor. Em outras palavras, a ciência deve começar com o dado, com certo fenômeno que aparece na experiência humana, e, pois, tendo iniciado [a investigação], proceder com a análise do fenômeno e ir ao estudo das partes, de suas interrelações e relações com outros elementos e com outras áreas conhecidas pela ciência. Enfim, ao termo, a ciência deveria retornar ao ponto de onde ela iniciou, aos fenômenos originais observados, e nos contar novas coisas sobre eles, que, após esse processo [investigativo], poderemos melhor compreender, manipular e dirigir (KILPATRICK, 1941, p.90, tradução nossa).

Segundo Kilpatrick, o que ocorre com os psicólogos mecanicistas é que

eles iniciam com algum dos mais distintos processos humanos da experiência, como pensamento, significação, desejo, sentimento de obrigação moral e, de forma alguma, retornam à experiência original. Ou se eles retornam, apresentam-na a nós como forma reduzida ou pervertida, [de modo] que passamos a saber menos ainda que antes (ibidem, p.91, tradução nossa).

Diante desses dois impasses, o primeiro, de desconsideração da vida humana em sua complexidade; o segundo, de perda do caráter científico do método de investigação, Kilpatrick lança luz à possibilidade de se pensar a educação sob uma outra psicologia.

\subsection{A PSICOLOGIA COMO RUPTURA DO PARARELISMO MENTE-CORPO}

A crítica de Kilpatrick contra o behaviorismo se dá em função do desinteresse por parte dessa psicologia em conceber o ser humano em sua complexidade. Para o autor, a psicologia necessita superar a visão cindida dos fenômenos do comportamento humano que considere haver em um dos lados um princípio causal e do outro um princípio não-causal.

Pautado no princípio deweyano de continuidade (Cf. COSTA, 2016), Kilpatrick considera que o problema do paralelismo mente-corpo pode ser posto como um problema de continuidade e descontinuidade (KILPATRICK, 1941, p.113-119). Nesse sentido, a seguinte análise crítica realizada pelo autor é de suma importância para se compreender os limites dentro dos quais se encontra a psicologia behaviorista.

A partir do princípio de continuidade e dentro do campo da psicologia, é possível supor uma escala onde estão distribuídos os vários aspectos do comportamento humano. No limite inferior estariam os sistemas mais simples da pessoa; no limite superior, a mais alta funcionalidade da personalidade consciente de si própria.

Seguindo essa lógica, um pouco acima do limite inferior estaria o comportamento das células, cujo funcionamento se assemelha em muito com o comportamento integrado dos 
animais dentro de um ecossistema. Acima desse estariam as funções de digestão, respiração e batimentos do coração, que embora complexas, não funcionam de forma intencionalmente dirigida. Acima viriam apetites de fome, sede, e de reprodução, que não estão sob definitivo controle, porém encontram-se sob consideração consciente. Acima desses viriam hábitos e outras funções que servem às necessidades humanas, mas não dirigidas com total domínio pelo pensamento consciente. E, finalmente, no topo da escala, viriam as mais altas instâncias de propósito inteligente, pensamento crítico, criação artística e conduta moral (KILPATRICK, 1941, p.113-114).

De fato, uma escala contínua incluiria todos os fenômenos do comportamento humano, e, se fosse interessante compará-la a uma escala relativa ao comportamento animal, essa equivaleria ao lugar mais baixo da escala humana.

Quanto ao homem, qualquer estudo de seu comportamento que pretendesse ser completo não o seria sem considerar toda a extensão da escala relativa ao seu comportamento, visto que, qualquer um dos aspectos, mesmo os localizados nos extremos da escala, cooperam de algum modo no comportamento geral. Desconsiderar a priori a influência de qualquer elemento, como fazem os behavioristas, seria comprometer a cientificidade da análise.

Para evidenciar de forma radical a descontinuidade presente na visão behaviorista do comportamento, Kilpatrick elabora uma argumentação sob um ponto de vista filogenético acerca da natureza do comportamento humano.

O autor inicia essa argumentação considerando o mundo natural dentro de um espectro. No limite inferior estaria a água e sua emergência na Terra. Todo o espectro encontra-se circunscrito às leis da física. Pouco acima da água estariam formas primitivas de vida. A vida em si originou-se, de algum modo, a partir de componentes físicos. Contudo, até o momento não há nenhum estudo que permitiria a alguém prever o surgimento da vida e seu comportamento. Nesse caso, pode-se dizer que a vida emergiu da matéria, uma forma de vida primitiva.

Considerando-se o comportamento humano cônscio como o outro limite do espectro, perceberemos a descontinuidade que há entre esse limite do espectro e a concepção do comportamento humano em termos de substâncias químicas ou em relação a outros animais.

Essa descontinuidade está presente na concepção de psicologia que pretende estar em posição de continuidade, por exemplo, com a física newtoniana. Qual o grau de continuidade que essa psicologia estabelece entre o comportamento animal e o humano, sendo que o comportamento humano em si possui um espectro maior se comparado ao do animal? 
Por essa razão, uma psicologia que pretendesse estudar o comportamento humano levando em consideração a continuidade presente no mundo natural e consequentemente presente no comportamento humano, poderia certamente lançar mão do princípio de continuidade presente no processo self-other, processo, esse, a partir do qual Mead fundamenta a formação da personalidade (KILPATRICK, 1941, p.116).

O dualismo cartesiano e a consequente relação de causalidade presente no paralelismo mente-corpo conduziriam a pelo menos duas situações. A primeira é que mente e corpo não podem interagir. Nesse caso, mente não faria parte da natureza. No caso de considerar, ainda, a possibilidade de interação entre mente e corpo, a dificuldade estará em estabelecer, no interior do sistema, a causa inicial de um dos dois.

Indubitavelmente, os eventos do comportamento interpenetram uns nos outros e cada evento da experiência humana tem muitos fatores determinantes e não somente uma "causa". E essa é, segundo Kilpatrick, a preocupação dos cientistas: encontrar os determinantes para as várias matérias.

Porém, nessa busca por fatores determinantes do comportamento humano, esses estudiosos acabam por introduzir em suas pesquisas dois lapsos metodológicos, um relativo à evolução da vida na terra e o outro relativo ao método de análise e descrição dos fenômenos observados.

Esse tipo de questão ocorre quando se pretende estabelecer por analogia direta leis do comportamento humano a partir de experimentos com animais. O comportamento humano, como foi dito, possui um espectro maior de fatores determinantes que o espectro do comportamento animal. Por essa razão, estabelecer uma analogia direta entre o comportamento humano e o comportamento animal sem a devida consideração dos níveis de complexidade que envolvem as várias formas de vida, tributários de milhões de anos de evolução, não parece ser um procedimento científico. Do mesmo modo, afirmar que o "fator B" é a causa do “comportamento A" implica uma redução e uma simplificação da natureza e da dimensão do leque de fatores determinantes do comportamento humano.

O comportamento humano, incluindo o plano simbólico e a personalidade, será reconhecido como parte da natureza na medida em que sua emergência for esclarecida dentro de sua história evolutiva enquanto espécie, considerando, inclusive, o desenvolvimento da linguagem e da cultura. 


\subsection{CRÍTICA À OBJETIVIDADE NEWTONIANA APLICADA ÀS CIÊNCIAS HUMANAS}

A crítica de Kilpatrick ao behaviorismo, tratada anteriormente, deu-se, em suma, por duas razões, a saber: a primeira, pautada na leitura fragmentária feita pelos behavioristas acerca do aspecto filogenético do desenvolvimento humano; a segunda, pautada no reducionismo com o qual essa psicologia vinha analisando e descrevendo o comportamento.

Porém, essa crítica ao behaviorismo é, por sua vez, parte de uma crítica mais ampla do autor, relacionada à aplicação nas ciências humanas - inclusive na educação - de metodologias próprias das ciências naturais sob a justificativa de se garantir a objetividade científica.

Segundo Kilpatrick, o problema da objetividade científica é tributário do dualismo cartesiano, que separa mente de matéria, ou "substância pensante" de "substância extensa". Kilpatrick afirma que esse dualismo remonta à Platão e que fora negligenciado pelos newtonianos, que, por não o considerarem pertinente, ativeram-se à matéria em seu sentido mais direto. Da física newtoniana, então, surgiu a noção mais difundida de objetividade científica.

O conceito newtoniano de objetividade subentende abarcar um determinado rol de elementos de modo isento, supondo não haver nenhuma interação entre o cientista e a situação, como se esse a concebesse "pelo lado de fora". Kilpatrick, por sua vez, afirma que em qualquer situação em que houver a presença humana, haverá o processo de subjetividade, visto que, por mais bem controlados que estejam o ambiente e as variáveis do experimento, esses dependem de mais de uma pessoa para garantir que não fujam às condições estabelecidas, e mesmo para avaliar os resultados ou para comunica-los de forma adequada a outros cientistas.

São fatores que dependem de uma relação intersubjetiva, a qual não ocorrerá sem cooperação e julgamento. O nível de objetividade, dentro desses moldes, é diretamente proporcional ao nível de independência que a lei resultante da experimentação teria em relação às condições do ambiente e mesmo à interpretação humana. E embora as leis científicas têm levado, em certo sentido, o homem a inclinar-se diante delas, e não o contrário, a objetividade, mesmo sob esses aspectos, deve visar não à eliminação do elemento humano, mas ao serviço da ciência em prol de uma vida melhor (KILPATRICK, 1941, 67-68).

De forma alguma Kilpatrick pretende invalidar os processos de experimentação da Física ou as leis que derivam desses processos: a intenção do autor é a de explicitar o sentido de objetividade da ciência e, então, realocá-la em seu papel de melhoria da vida.

$\mathrm{Na}$ verdade, Kilpatrick, pautado no princípio meadiano de self-other, pretende colocar o critério de objetividade científica em novas bases, sem com isso, resultar na negação do 
estatuto de ciência das ciências humanas. Essas bases, por sua vez, embasarão também o ensino e a pesquisa em educação.

\subsection{A EDUCAÇÃO PENSADA A PARTIR DA NOÇÃO MEADIANA DE SELF}

Como dito anteriormente, ao mesmo tempo em que Kilpatrick questiona as práticas pedagógicas e científicas de inspiração behaviorista e o próprio Behaviorismo como ciência, o autor apropria-se de um paradigma de psicologia cujo núcleo compreende o processo self-other.

Esse processo, composto pelo self ("si mesmo") e pelo other (“outro generalizado"), foi cunhado a partir da psicologia de George Herbert Mead. A terminologia em inglês refere-se à utilizada por Kilpatrick em Identidade Pessoal e Civilização: um estudo do processo self-other.

O termo other - utilizado por Kilpatrick - refere-se, como foi citado, ao conceito meadiano de "outro generalizado", que consiste

[...] numa representação simbólica da vontade coletiva. Trata-se da dimensão normativa da comunidade social, que se estrutura na forma de um horizonte e que orienta as atitudes dos distintos indivíduos. [...] [A atitude do outro generalizado] expressa-se em objetivos, valores, regras, costumes, sentidos e reações organizadas que não podem ser reduzidas somente à dimensão da moralidade (CASAGRANDE, 2014, p.74).

O termo self, por sua vez, designa a auto compreensão reflexiva sobre si mesmo, ou seja, trata-se da autoimagem, do autoconceito. O self é uma estrutura composta pelo eu interno e pelo outro interno, sendo que o eu interno

consiste na dimensão não previsível do self, no elemento que nos identifica enquanto únicos e singulares, que não é dado diretamente na experiência. Ele não pode ser objeto da consciência. [...] [O eu interno] emerge da ação criativa do indivíduo diante de uma situação social. Trata-se da novidade do momento, do ineditismo da reação ao dado, com uma orientação a um futuro indefinido. É uma reação que não pode ser prevista, tampouco antecipada (ibidem, p.7778).

O eu interno, por sua vez, somente será capaz de se colocar na posição de objeto, enquanto consciência de si, por meio da ação e do conteúdo do outro interno, o qual

contempla as convenções e as atitudes generalizadas dos outros. É a dimensão que mantém a estabilidade das ações e das reações do self, pois está pautado nas convenções do todo social: [...] [o outro interno] é convencional (ibidem, p.78-79).

Mead correlaciona os processos onto e filogenéticos do desenvolvimento humano, que correspondem, respectivamente, ao desenvolvimento do indivíduo ao longo de sua vida e ao 
desenvolvimento do ser humano enquanto espécie. Para Mead, ambos os processos são indissociáveis e se constituem mutuamente, pois, se trata

de uma simultânea construção-reconstrução pessoal e social sob o prisma de uma fundamental interdependência. Desse modo, a sociedade é condição de emergência do self, e este consiste na base ou pressuposto da evolução da sociedade. Ou seja, a história da espécie humana (filogenia) e a história das pessoas individualmente (ontogenia) são processos indissociáveis, pois a filogênese e a ontogênese são dois aspectos distintos do mesmo processo evolutivo. Se, por um lado, a existência da sociedade e, especialmente da comunicação simbólica, consiste na precondição do desenvolvimento da pessoa humana, por outro, são as pessoas que possibilitam a existência de uma sociedade distintivamente humana (CASAGRANDE, 2014, p.27).

Kilpatrick, em Identidade Pessoal e Civilização, expõe um estudo histórico sobre a origem e o desenvolvimento da identidade pessoal tomando como fio condutor a psicologia de Mead, e em seguida aborda algumas das possíveis consequências e contribuições dessa teoria para educação.

Para tanto, Kilpatrick parte da tese de que a identidade pessoal, cujos elementos são, entre outros, a linguagem, o pensamento crítico, o senso de responsabilidade, a consciência e a utilização de convenções sociais - é um produto inerentemente social e, como tal, é formada necessariamente pelo processo self-other.

Sobre essa tese, diz, Kilpatrick (1941, p.01, tradução nossa): “a operação do processo self-other enquanto realização histórica foi e ainda é essencial tanto para as individualidades quanto para a civilização.”.

\subsection{A FORMAÇÃO DA IDENTIDADE PESSOAL}

Kilpatrick, quando trata da natureza social do self e da formação da identidade pessoal, faz referência direta à obra Mind, self and society, de Mead (ibidem, p.38).

Por identidade pessoal entende-se o conjunto daquilo que, na e segundo a pessoa, a torna quem ela é. Em outras palavras:

a consciência de si mesma em relação aos outros; consciência do passado, presente e futuro e, consequentemente, a concepção de si mesma como uma entidade permanente; a capacidade de sentir esperança, medo ou prazer, juntamente com os significados vistos; a capacidade de agir como causa consciente, de planejar e de executar planos; a capacidade de aceitar a responsabilidade pelo que se faz, de desenvolver a consciência e agir com moralidade consciente. Em conexão com tudo isso, cada pessoa desenvolve normalmente o traço especificamente humano de respeito próprio e, ao mesmo tempo, a possibilidade de uma consideração semelhante pelos outros (ibidem, p.114, tradução nossa). 
A exposição teórica acerca da formação da identidade pessoal assim como suas derivações e possibilidades como fundamento para se pensar a educação são tratadas com ênfase por Kilpatrick em Identidade Pessoal e Civilização: um estudo sobre o processo selfother após serem introduzidas em Reformulando o Currículo e, em Filosofia da Educação, serem tratadas de modo articulado a outros assuntos.

Em Identidade Pessoal e Civilização, o autor faz algumas considerações acerca da natureza da identidade pessoal, a saber: a) ninguém nasce com um self constituído, nem a identidade pessoal é meramente uma questão de maturação interna: necessita ser formada; b) de todos os organismos vivos, o homem é o único capaz da constituição de uma identidade pessoal; c) o processo de formação da identidade pessoal estende-se por vários estágios e níveis; d) esta identidade pessoal é formada somente e necessariamente em um ambiente social, sendo que a cultura participa como elemento constituinte e consequentemente como resultado do processo; e) a consciência de si e a consciência acerca do outro emergem simultaneamente na identidade pessoal, cada qual se desenvolvendo e contribuindo mutuamente durante toda a vida, uma na formação da outra; f) desde o início do processo de formação do self e do other, cada qual é composto e afetado tanto pelo eu interno quanto pelo outro interno, e o resultado é um processo cognitivo do qual dependem tanto a identidade pessoal quanto a sociedade (KILPATRICK, 1941, p.01-02).

\subsubsection{O self}

Kilpatrick, em Identidade Pessoal e Civilização, com vistas a elucidar o conceito de self, inicia sua argumentação com um exemplo do cotidiano: a partir do comportamento observável de uma criança.

A criança, conforme ilustra Kilpatrick, terá constituído seu self, em alguma medida, se: a) claramente distingue ela mesma dos outros por meio da utilização de pronomes como eu, mim, meu, minha, você, seu, ele ou ela, dele ou dela; b) reconhece ela mesma como agente, alguém que pode de alguma maneira modificar o ambiente e se vê utilizando expressões como "eu não consegui fazer isto, mas minha amiga conseguiu", ou "eu consigo arrumar a cama sozinho, não preciso da ajuda de ninguém"; c) desenvolveu noção de tempo, de passado e de presente, e a noção de continuidade de si própria e, por isso, utiliza expressões como "irei para a casa da minha avó amanhã. Na verdade, estive lá nas últimas férias e meu avô mostrou-me o bezerro, mas mamãe disse que ele está maior agora"; d) constituiu um senso de consciência 
intencional e de responsabilidade, como é notório em "eu machuquei a mão do João, mas foi sem querer.".

Como se nota, a noção da criança acerca da própria individualidade pressupõe minimamente operações de natureza pessoal ativa e intencional, pautadas em elementos pragmáticos como contexto cultural e expressão linguística (KILPATRICK, 1941, p.02-03).

\subsubsection{Estágios de desenvolvimento da identidade pessoal}

A identidade pessoal, cuja formação se dá durante todo o curso da vida, envolve três estágios que, na medida em que surgem, tendem a afetar-se mutuamente. Além disso, a partir do momento em que surgem, passam a ser permanentes.

O estágio mais primitivo é o relativo aos reflexos e comportamentos inatos, como batimentos cardíacos, respiração, digestão e afins (ibidem, p.32).

\subsubsection{O primeiro estágio}

Kilpatrick afirma que anterior ao primeiro dos três estágios do self, há um período que é dividido em duas etapas: a primeira durante o período embrionário; a segunda, com o surgimento de uma consciência, porém limitada e ainda incapaz de voltar-se para si. Essa etapa se dá entre o nascimento e o surgimento de fato da consciência de si, capaz de reconhecer-se como indivíduo.

Após essas etapas, vem o primeiro estágio propriamente dito de formação do self, quando a criança aprende a discriminar a si mesma dos outros por meio da confluência de dois componentes, a saber: os elementos da experiência particular e interna, como desejos e sentimentos; os elementos primeiramente ou mais agudamente perceptíveis nos outros, como habilidades de segurar objetos ou falar.

Após essas aprendizagens, a criança gradativamente passa a referir-se a si própria como "eu" em vez de se utilizar do próprio nome; surgem: a capacidade de agência, quando é comum dizer "eu que fiz isso!”, o senso de dever moral: "eu fiz, mas foi sem querer!”, e a noção temporal aplicada a si própria, como em "ontem fez frio, por isso eu vesti a blusa antes de sair de casa. Amanhã, se fizer um dia quente, poderei sair de casa somente de camiseta." (ibidem, p.17). 
O primeiro estágio atinge seu ponto de maior elaboração quando o self da criança se encontra organizado numa nova estrutura composta de self e other, sendo que cada uma dessas partes, por sua vez, tende a se compor pelo eu interno e o outro interno.

\subsection{O processo de formação interna das coisas durante o primeiro estágio}

Com o processo preliminar da formação do self existe o processo de construção mental relativo às coisas do ambiente, o qual se dá por meio de um incontável número de experiências que se inter-relacionam. Kilpatrick exemplifica essa construção mental com uma experiência infantil hipotética, como segue.

Ao se utilizar diversas vezes da mamadeira, a criança aprende a reconhecer o que é e o que não é mamadeira, pelo formato, pelo aroma ou por outra característica, ao mesmo tempo em que, gradativamente, aprende a ajustar-se ao seu manejo.

E ao mamar associa prazer e, mais tarde, ao ficar com fome, atenta-se para a chegada da mamadeira, quando, então, coloca-se em posição para agarrá-la e sugá-la. Todas essas experiências, as visíveis e as internas, vão sendo associadas na "mente" da criança (aspas do autor), de modo que a criança passa de uma situação perceptiva confusa e indeterminada para uma em que há algo que se diferencia do ambiente. O fato de diferenciar um objeto de um ambiente caótico significa imprimir, nesse objeto, existência própria, algum significado e mesmo expectativas em relação a sua aparição, como foi dito. Esse processo de constituição das coisas é algo natural nos seres humanos.

As palavras associadas à situação são outra natureza de experiência - a experiência semiótica - e auxiliam na cristalização da situação. As palavras ou sinais vão sendo discriminadamente incorporados como significantes de certos objetos em função de seu comum reconhecimento por parte das pessoas do grupo, ao mesmo tempo em que esses objetos passam a ser discriminados em relação ao todo. As palavras suscitam internamente todo o comportamento do grupo e a situação em torno dos objetos significados.

É notório o caráter social da aprendizagem que subjaz às situações descritas por Kilpatrick, pois, é no contraponto entre as necessidades da criança e as respostas do ambiente que se dá a regulação interna da criança e, então, com o intuito de auto preservar-se, ocorre a adaptação ou aprendizagem. 


\subsection{Surgimento da unidade interna do self}

Enquanto o mundo externo, ou mundo das coisas, assume corporeidade para a criança, essa, internamente, desenvolve sua capacidade de agência, ou seja, capacidade de direcionar recursos internos para efetuar atos intencionais. Sua habilidade em se utilizar de meios para atingir certos fins, como chorar para ganhar atenção, é apenas uma das habilidades que compõe sua capacidade de agência nos primeiros estágios de formação do self.

Com o passar do tempo, vão se formando no self duas unidades internas permanentes, que se desenvolverão na forma de eu interno e outro interno, como será explanado adiante, neste trabalho. No período inicial de formação do self, há principalmente a ação de sentimentos coadjuvantes que auxiliam na promoção de atos de esforço. Quando a criança encontra obstáculos, ela empregará esse esforço para uma possível superação dos obstáculos em questão.

Ao longo do processo de vivência de maior esforço e de sucessos e fracassos, internamente a criança passa a estabelecer um sistema que infere sentimentos agradáveis de sucesso a coisas amigáveis e sentimentos desagradáveis de fracasso a coisas hostis. A criança

também passa a antagonizar esses sentimentos. É na permanência desse sistema, especialmente quando há envolvidos sentimentos de esforço, que se encontra o início do senso permanente de identidade pessoal (KILPATRICK, 1941, p.06).

\subsection{Surgimento e desenvolvimento simultâneo do self $e$ do other}

A interação entre os dois mundos - o "externo" das coisas observáveis, e o "interno" do querer, da dor, do prazer e do esforço - tende a tornar-se mais complexa; aquilo que a criança desenvolveu ou percebeu em um mundo começa, então, a lançar luz sobre o outro.

Desde o início da infância, a criança passa progressivamente a perceber e a coordenar o movimento das pernas e braços, o que depois se estenderá a mãos e pés, e finalmente aos dedos. Ao mesmo tempo em que esse processo ocorre, ela gradativamente vai correlacionando os gestos feitos com seus membros e as respostas do ambiente, respostas, essas, por exemplo, em forma de uma sequência regular de sons ou gestos faciais de alguém que está por perto.

Embora, nesse momento, ela ainda não seja capaz de distinguir a si própria do ambiente, os sons que compõem as palavras "pezinho", "mãozinha”, "perninha”, "bracinho" etc., de mera sequência aleatória, vão se tornando padrões cada vez mais familiares, assim como a percepção visual de seus membros. 
Com o passar do tempo, a criança pode perceber que há alguém ao seu lado, maior que ela. Pode perceber que essas pessoas também possuem pés e mãos e que, de alguma maneira, parecem-se com os seus e que também se movem. Pode notar também que os seus pés e os da criança que dorme ao lado são pequenos, e notar que os das outras pessoas são maiores, e, mais adiante, perceber, em meio à combinação das imagens de seus pés com a imagem dos das outras pessoas e os sons que frequentemente são proferidos enquanto ela os observa, que tanto os seus como os dos outros, são todos "pés” (KILPATRICK, 1941, p.07).

Com o passar do tempo, há também uma correlação, feita pela criança, entre o fato de ela ter um nome e a outra que dorme ao lado também. São correlações entre formas, sons e atitudes que permanecerão internamente e que, a partir da quais, serão construídas outras.

Chegará um dia em que a irmã da criança cairá e, possivelmente, chorará. A mãe dirá à criança que a irmã caiu, feriu a cabeça e por isso está chorando. Num outro dia, a própria criança cairá, ferir-se-á e chorará. E a mãe, então, dirá a ela que do mesmo modo que está doendo para ela, também doeu para a irmã quando essa caíra. Nessa situação, mesmo que, obviamente, a criança não tenha acesso à percepção da dor física alheia, inserir-se-ão mais elementos perceptivos e cognitivos para a distinção entre o que faz e o que não faz parte do próprio corpo. Dessa maneira, gradualmente a criança irá corporalmente perceber-se como uma entre outras, e, consequentemente, perceberá que o que ela própria sente pode ser aplicado às outras.

Do ponto de vista da formação do self, a criança que se percebe distinta do ambiente, das outras crianças e percebe por meio da interação social que há uma semelhança corporal entre as pessoas e que, se o ferimento dói para Maria, o mesmo acontecerá com ela própria e vice-versa; a criança entra em um nível mais complexo de desenvolvimento do self, quando ela, a seu modo, torna-se capaz de enxergar "do lado de fora" a si própria e, por meio de uma relação de similaridade, passa a projetar imageticamente nas outras pessoas o que por si própria sente e vê, mesmo fatores internos, como sentimentos, emoções ou mesmo sensações físicas (ibidem, p.07, aspas do autor).

Este é o ponto de partida para o surgimento do other como um self e do self como um other.

Embora a formação do self esteja em seus primeiros estágios e é pouco complexa, já se manifesta como um processo composto em parte do que a criança percebeu em si própria e em parte do que ela percebeu nas outras pessoas. A criança, nesse sentido, age a partir de um self que gradativamente conhece a si próprio. Esse conhecer se deve à relação entre o self e o other, os quais emergem simultaneamente e fornecem elementos um para a formação do outro. 
Mas o que ocorre na relação self-other? De que forma o other é assimilado pelo self e de que modo o self pode enxergar a si mesmo?

Para Kilpatrick, assim como para Mead, o other é

a resultante da internalização pelo indivíduo de um reflexo generalizado da atitude do outro. Esse reflexo generalizado, pode ser encontrado, por exemplo, no significado da palavra, núcleo da linguagem verbal destituído de toda materialidade (SASS, 1992, p.244).

A natureza do other, para Mead, "pode ser um indivíduo que encarne uma função da sociedade, um agrupamento social e até mesmo objetos físicos” (ibidem, p.246).

Para a criança do exemplo de Kilpatrick, a irmã será sempre um reflexo generalizado do que seja uma criança e uma irmã, por exemplo. A experiência com a irmã é particular, porém seu reflexo, internalizado pela criança, é refletido generalizadamente.

A internalização pela criança do reflexo generalizado do ambiente significa "a internalização de uma atitude organizada e generalizada do real, um outro generalizado (other) [...] e é o outro generalizado que proporciona a unidade do self [...].” (ibidem, p.246).

Uma vez iniciada a formação do self, essa se estenderá por toda a vida. Seus limites e possibilidades são atrelados à qualidade das experiências vivenciadas pelo sujeito ao longo da vida. Diz, Kilpatrick:

Até que alguém tenha vivido o suficiente, qualquer literatura, mesmo a mais simples, será um livro fechado. Até que alguém tenha amado, não poderá compreender o amor de outrem. Até que alguém tenha sofrido o luto, não poderá compreender em sentido pleno esse sentimento (KILPATRICK, 1941, p.08, tradução nossa).

O self e o other estão em constante marcha de desenvolvimento enquanto houver interação pela experiência, mesmo na fase adulta. Hipoteticamente, imagina-se haver um casal de namorados. Pedro sente-se atraído por Mônica e percebe que é recíproco. É a primeira vez que Pedro vivencia esse sentimento e, então, imagina a seu modo, ou seja, generalizadamente, como deve ser para ela também vivenciá-lo. De todo modo, mesmo Mônica tendo se relacionado com outros rapazes, a Pedro não será possível vislumbrar em sentido pleno o que Mônica sente, pois uma projeção intelectiva, mesmo que apoiada no significado das reações emocionais em si próprio, não tem a mesma natureza ôntica da experiência "em primeira mão" do sentimento de Mônica. Pedro, nesse sentido, sempre vislumbrará um reflexo generalizado do que Mônica sente, e vice-versa.

Uma leitura deweyana desse processo e do exemplo do casal, sugeriria que o self de Pedro é composto por suas experiências reflexivas e emocionais internamente vivenciadas e 
significadas, ou seja, seu self visto pelo "lado de dentro", e um tipo específico de experiências significadas da percepção de Pedro de como o mundo o vê, de como os outros seres reagem a ele: o self supostamente visto "pelo lado de fora", supostamente percebido pelo other. $\mathrm{Na}$ perspectiva de Pedro, o other compreende um composto de experiências de percepção do ambiente, que inclui outras pessoas, objetos e atitudes e que são significados e impregnados de sua da própria experiência de vida, ou seja, impregnadas de seu self. Em suma, ao mesmo tempo em que o ambiente possibilita experiências originais, essas são significadas segundo seu lastro interno de experiências de vida, e essas últimas, por sua vez, são significadas segundo seu self visto "pelo lado de dentro" e seu self visto pelo "lado de fora". Esse conceito de self, composto por um eu interno particular e inédito e um outro interno convencional é, como foi dito, o conceito meadiano de self, o qual foi apropriado por Kilpatrick.

Sobre a formação do self em seus primeiros estágios, diz, Kilpatrick:

o self é, portanto, como dito anteriormente, uma forma composta por ambas as fontes. Uma parte veio diretamente da própria experiência "interna" da pessoa; a outra parte veio da observação das vidas de outros. Depois de inauguradas, as duas partes tornam-se intimamente imbricadas. E algo semelhante ocorre com minha concepção dos outros. Cada outro é por mim composto de coisas que eu vira primeira ou peculiarmente em outros, mas também de coisas que eu atribuo ao outro porque eu as sei em mim próprio (KILPATRICK, 1941, p.08, tradução nossa).

Em suma: o self não é capaz de existir sem sua parcela de other, pois a visão recíproca (reflexiva) do eu interno não oferece, onticamente, material a priori para que se efetue sequer a linguagem.

Por exemplo, uma criança ao perceber que o colega está triste oferece-lhe companhia. A questão é: como ela supõe que o colega está triste? E como ela sabe que quando se está triste, uma companhia certamente será bem-vinda?

Ela supõe que o colega está triste porque sua memória de significados oferece informações suficientes para identificar uma pessoa triste, significados esses resultantes tanto da percepção de outras crianças tristes como da percepção de si própria quando esteve triste.

O significado de tristeza pode surgir de infinitas maneiras. É possível à criança dizer que o outro está triste porque um dia viu alguém que estava "diferente" e esse alguém lhe dissera que estava "diferente" pois estava triste, por isso agia daquela maneira ou, um dia, a própria criança estava se sentindo "diferente" e alguém lhe dissera que aquele "diferente" é chamado tristeza.

Esse movimento de reconhecimento da tristeza de outrem, ou do other, ocorre, na visão de Kilpatrick, a partir de duas fontes de significado: a tristeza vista e descrita por outras pessoas 
- generalizada - e a tristeza vivenciada por ela própria, caracterizada como tristeza a partir da percepção da tristeza alheia. Para a criança, esse movimento soará como: "não é bom estar triste; eu, se estivesse triste, gostaria de companhia, portanto, devo também oferecê-la".

Note-se que a percepção e o julgamento da hipótese de alguém estar ou não triste, inclusive uma autopercepção e um autojulgamento, são mediados pela linguagem. E, dentro da mesma lógica, encontra-se a gênese do conceito de tristeza, que consiste na experiência semiótica de percepção e significação da resultante generalizada do comportamento de outrem e do próprio.

Evidencia-se, por esse processo, primeiro: a natureza pessoal e social do self, que bebe da fonte das experiências próprias e do ambiente, que tem a linguagem tanto como elemento dessa experiência quanto ela própria enquanto experiência; segundo, a ruptura das dicotomias indivíduo-sociedade e mente-corpo, corroborada pelo núcleo darwiniano relativo à adaptação organismo-ambiente.

O processo de individuação e de formação da identidade pessoal por meio do processo self-other e sua consequente formação da agência pessoal encontram-se em seu primeiro estágio quando for notório a criança ser capaz de olhar para si própria segundo o modo como os outros supostamente a veem e, então, ser capaz de ponderar seus atos não apenas pautada em seus critérios, mas também no que acredita que sejam os critérios dos outros. É a partir de então que tudo o que faz conscientemente o faz segundo seu novo self. Desse modo, a individuação e a identidade pessoal se assentam na indissociabilidade indivíduo-sociedade e, do mesmo modo, desenvolvem-se sob essa relação os processos intelectivo-morais de pensamento.

\subsection{O desenvolvimento da agência e do senso de dever moral durante o primeiro estágio}

Como foi dito, com o passar do tempo e a vivência em sociedade, o self assume novas características como, por exemplo, a consciência de si e o senso de dever moral.

Dentro do período correspondente ao primeiro estágio de desenvolvimento da identidade pessoal, ocorre a passagem de um nível pré-fala para o nível de fala, quando essa tende a incorporar-se ao comportamento e, com isso, constituir uma unidade de agência.

Das primeiras gesticulações sem verdadeira intenção comunicativa até a aquisição das primeiras expressões intencionalmente comunicativas, a criança vai, gradualmente, constituindo sua agência consciente de si.

A ausência de consciência sobre a própria ação significa proporcionalmente ausência de capacidade de propósito. À medida que a criança, por meio de consecutivas experiências, 
desenvolve a percepção de que ela possui desejos e é capaz de efetivá-los, surgem os primeiros sinais de autonomia e, ao mesmo tempo, surge o interesse por explorar o desconhecido e por se auto afirmar enquanto indivíduo.

Essa nova forma de agência, segundo a qual a criança se vê capaz de "fazer acontecer" ", sugere, por sua vez, a necessidade de uma pedagogia que esteja mais em consonância com essas características psicológicas, a saber, consciência de si e agência autodirigida.

Nesse sentido, essa dinâmica de aprendizagem e de desenvolvimento devem nortear uma nova forma de educação, que pode ser alcançada por meio do método de projeto (KILPATRICK, 1941, p.13).

\subsection{O senso de dever moral}

O desenvolvimento de agência consciente de si na criança não opera independentemente do ambiente, mas em constante relação com esse no que tange ao imperativo da cultura e das instituições. À medida que a criança ganha autonomia de agência, aprende que as ações têm consequências e, então, dentro de uma lógica moral radical, cujos extremos são o certo e o errado, a criança age dentro de um regime de culpabilização por acreditar não haver posição intermediária no espectro moral.

Se por um lado é frequente recair sobre a criança a cobrança por uma conduta incompatível com seu então nível de responsabilidade intelectual-moral, por outro, a ausência de responsabilização desde os primeiros anos da infância em nada contribuirá para seu desenvolvimento moral.

A aprendizagem deve se pautar no quão possível é para a criança ou para o adulto enxergar a multiplicidade de consequências de seus atos, em função da natureza de suas experiências pessoais de vida e levando em consideração uma ética democrática. Uma educação nesses moldes deve problematizar o comportamento infantil a partir dos limites e possibilidades de cada criança, e em cada contexto histórico-social, ao mesmo tempo em que toma como parâmetro ético a vida verdadeiramente democrática numa sociedade sempre em mudança.

Espera-se, portanto, que seja uma aprendizagem significativa e vinculada ao ambiente. Tal objetivo poderá ser alcançado por meio da vivência social e inteligentemente dirigida na vida cotidiana e, principalmente, na escola.

\footnotetext{
${ }^{8}$ A expressão utilizada por Kilpatrick é "I can bring things to pass".
} 


\subsection{A moral tradicional na formação da identidade pessoal}

Segundo Kilpatrick, a cultura ocidental cristã tem sustentado uma educação moral baseada na culpabilização incondicional, pois o "pecado original”, tido como justificativa para qualificar o ser humano mais pelo que lhe falta do que por suas potencialidades, está presente como pano de fundo da educação tradicional.

Para Kilpatrick, esse paradigma moral distancia-se em grande medida do paradigma moral vivido pelos gregos, que não partilhavam dessa noção de pecado ou de culpa.

Essa afirmação explicita a hipótese de Kilpatrick de que um dos caracteres essenciais da identidade pessoal, o dever moral, em qualquer época da história, pode ser, do ponto de vista do desenvolvimento, mais ou menos potencializado em função da cultura predominante na época e no grupo em que se encontra a pessoa. Ou seja, as crianças educadas em uma sociedade como a grega demorariam mais para formarem no caráter a concepção negativa de dever moral, originária da culpa (KILPATRICK, 1941, p.15).

Apesar de aparentemente parecer uma conclusão óbvia, vale ressaltar que nesse argumento subjaz a ideia de que o desenvolvimento do caráter não resulta apenas do desenvolvimento interno do indivíduo, pois, se assim fosse, crianças em diferentes culturas desenvolveriam as mesmas características pessoais. Em outros termos, Kilpatrick está afirmando que em função da presença ou da ausência de certos elementos da cultura, o desenvolvimento intelectual-moral pode se dar numa certa direção ou em outra. Desse modo, o autor reafirma a plasticidade da inteligência humana, do ponto de vista psicológico, e, corolariamente, reafirma sua adaptabilidade à mudança, conforme argumentou em Educação para uma Civilização em Mudança.

\subsection{Senso de permanência do self}

Quando os elementos constituintes do self, como agência e dever moral entram em conexão com a crescente noção consciente de tempo, surge o senso da identidade permanente do self.

Essa habilidade é desenvolvida de maneira gradativa pela criança, desde a noção de intervalos de minutos até de anos, e requer a percepção de permanência ao longo do tempo de certos elementos de seu próprio caráter. Do mesmo modo com que percebe as permanências e as mudanças em si própria, a criança as perceberá nos outros, muitas vezes mais jovens ou mais 
velhos, o que, de algum modo, poderá lançar luz à percepção de si própria como ser em transformação.

Nesse sentido, a vida compartilhada entre crianças de diferentes idades ou mesmo entre gerações diferentes tende a formar um quadro social e individual de significados muitíssimo rico, já que a criança, ao conviver com o adulto, naturalmente é provocada a questionar-se sobre seu próprio futuro ou sobre o passado daquele adulto, pois, para ela, não é óbvio o fato de os adultos terem um dia sido criança.

4.6.2.2 O segundo estágio: desenvolvimento de linguagem, comunicação e significado

O segundo estágio da individualidade é alcançado mediante o desenvolvimento da linguagem. Seu papel não é a penas o de meio de comunicação, mas também o de constituição do pensamento por meio dos signos.

Apesar de animais não-humanos haverem desenvolvido muito seu poder comunicativo, por meio de sinais sonoros, de pigmentação ou mesmo por padrões de movimentos corporais, nenhum desses realiza qualquer desses fenômenos com intenção de comunicar significados. Nenhum desses opera, evidentemente, numa base self-other, visto que as reações instintivas que comandam sua "agência", sem que haja necessariamente qualquer adequação no código em função das demandas do receptor da "mensagem".

O balançar da cauda canino se dá em função unicamente da qualidade dos estímulos de entrada, sem levar em consideração o espectador. Embora a comunicação canina seja considerada uma espécie de linguagem, não oferece a possibilidade de representação dos objetos, como o fazem os signos linguísticos, e dessa maneira, não poderia ter o mesmo estatuto que a linguagem humana.

A linguagem humana, por sua vez, está intimamente relacionada com a natureza do receptor. As palavras que conscientemente são utilizadas por alguém são, primeiramente, dirigidas a si próprio, seu outro interno; e, ao mesmo tempo e hipoteticamente, ao other. Esse gesto comunicativo baseia-se num esquema self-other, pois o que importa ao emissor é o comportamento interpretativo de seu receptor após o recebimento da mensagem (KILPATRICK, 1941, p.19-21).

É notória a importância da natureza self-other da agência humana no que concerne à comunicação, sem a qual o desenvolvimento dos seres humanos enquanto indivíduos ou enquanto sociedade humana não seria possível. 


\subsection{O princípio da cooperação}

Como evidenciado anteriormente, o processo self-other supõe que cada um de seus polos é composto por uma parcela de si e uma do outro. Analogamente, a comunicação, pensada sob esse princípio, não pode ser reduzida um modelo bipartite. Emissor e receptor constituemse como duas individualidades em processo de self-other. A comunicação entre ambos opera, então, por meio de uma cooperação envolta por um contexto.

Kilpatrick dá o exemplo hipotético de uma enfermeira que é responsável por um paciente que necessita dormir. Ao deixar o quarto, após o paciente haver adormecido, deparase na porta com o médico também responsável pelo paciente. Ela, nesse momento, faz um gesto com o dedo indicador querendo dizer "silêncio" e logo o aponta na direção do paciente. Nesse mesmo instante, o médico compreende o significado de tais gestos e, juntamente com a enfermeira, sai pela porta e segue em direção ao saguão do hospital.

Durante o encontro, afirma Kilpatrick, médico e enfermeira partilhavam do mesmo fim: o bem-estar do paciente. Essa coincidência de interesses sustentou tanto a comunicação quanto a atitude posterior de ambos de deixar o paciente dormindo. A coincidência de momentos e de intentos (o profissional e o relativo àquele paciente), o conhecimento que cada um detinha sobre o outro e sobre a própria identidade de intentos (por meio do other e do outro interno, respectivamente) e uma convenção prévia de signos garantiram a cooperação de todos esses elementos, que culminaram na ação de deixar o quarto do paciente e dirigirem-se para outro local.

Essa espécie de comunicação intencional, que deduz seu significado da cooperação consciente para buscar um fim compartilhado é o que define linguagem em seu sentido pleno.

Segundo Kilpatrick, a habilidade de conscientemente cooperar e intencionalmente utilizar-se da linguagem para a comunicação no sentido então exposto constitui o segundo estágio do processo de formação do self (KILPATRICK, 1941, p.23-24).

\subsubsection{Terceiro estágio: conflito moral, responsabilidade pessoal, consciência}

O terceiro estágio de complexidade do self se dá em torno da questão moral. Kilpatrick cita James (2007, p.309-317) para afirmar que uma pessoa possui muitos diferentes "eus”, que são centros efetivos das diversas espécies de interesses do indivíduo, os quais, não raramente, rivalizam entre si. 
Apesar de a psicologia de James operar sob enfoque e conceitos diferentes dos de Mead expressos neste trabalho (Cf. SILVA, 2011), o cotejamento entre James e Mead é pertinente a Kilpatrick no sentido de explicitar a existência de uma infinidade de interesses que, em função de seu direcionamento, constituem centros internos que mobilizam, cada qual, os recursos do indivíduo relativos à sua efetivação. Cada centro efetivo de interesses é denominado por James “eu empírico". Desse modo, uma pessoa teria tantos “eus empíricos” quanto fossem os tipos de interesses que os constituíssem, conforme exemplifica James (2007, p.309, tradução nossa) de modo peculiar:

[Diante da] maioria dos objetos de desejo, a natureza física restringe nossa escolha a apenas um dos muitos bens representados, o mesmo ocorre aqui [enquanto escrevo]. Frequentemente, me deparo com a necessidade de me manter diante de um de meus eus empíricos e de abrir mão do restante. Não que eu não fosse, se pudesse, bonito, gordo e bem vestido, um grande atleta, ganhador de um milhão por ano, esperto, bon vivant, um assassino; bem como um filósofo, um filantropo, estadista, guerreiro e explorador africano, poeta e santo. Mas, a coisa é simplesmente impossível.

Kilpatrick, por sua vez, exemplifica a natureza conflitiva dos eus empíricos por meio de um exemplo hipotético: um garoto que deseja fazer algo escondido da mãe por essa não permitir que ele o faça. E por não ter o aval de sua mãe para fazer aquilo que ele deseja, surge o conflito interno. O garoto reconhecerá a existência de um eu parcial que tende a levá-lo contra a determinação da mãe, assim existirá outro eu que é a favor de obedecê-la.

Esse conflito, visto a partir do conceito meadiano de self e do princípio self-other e não mais nos termos de James, se dá em função do embate no self do garoto entre o eu interno e o outro interno, os quais rivalizam entre si com o objetivo de decidir qual dos dois terá maior influência na deliberação. Para esclarecer a questão, é pertinente a citação de Sass (1992, p.240, itálicos nossos):

O self é formado unitariamente pela reciprocidade entre o eu interno (ação do sujeito) e o outro interno (as atitudes da sociedade internalizadas pelo sujeito através do mecanismo da apropriação da atitude do other), cuja característica fundamental é a de possibilitar ao sujeito que ele se converta em objeto para si.

A partir do conteúdo das citações de Casagrande, da citação imediatamente anterior a este parágrafo e da análise de Kilpatrick a partir do exemplo do garoto, é possível afirmar que o conflito do garoto ocorre em função do embate entre o eu interno, desejoso de contradizer a mãe e o outro interno, cuja função é possibilitar que o garoto reflita e delibere sobre o próprio ato por meio do acesso ao conteúdo convencional generalizado. Nas palavras de Kilpatrick 
(1941, p.26, tradução nossa, itálico nosso): "nós temos aqui o outro interno que, na ausência da mãe, sustenta suas vontades, enquanto o eu interno representa o desejo de oposição da criança.".

Em outras palavras, é o embate entre o desejo e a convenção, a qual poderia representar o conceito que a mãe tem do garoto ou o conceito que o garoto tem acerca dos deveres dos filhos para com os pais. Nesse momento, inclusive, um senso tradicional de dever poderia intervir de modo a desenvolver um sentimento de culpa no garoto por desejar desobedecer a sua mãe.

\subsection{Consciência, conflito moral e responsabilidade}

Os conflitos morais surgem, como explanado, após a criança ter formado minimamente sua identidade pessoal e se tornam notórios, principalmente, por conta do contraste comportamental ocasionado entre seu antigo padrão de obediência à autoridade e o novo padrão moral de responsabilidade.

Para Kilpatrick (1941, p.27, tradução nossa, itálico nosso), conflito moral é "quando um eu interno está lutando contra as demandas de um outro interno em função da efetivação de certa regra em ato e fato exteriores", e o ato de decisão se caracteriza pela escolha por um ou por outro à luz das consequências previstas e à luz da ação conscientemente aceita.

Responsabilidade, em Kilpatrick, significa:

a) reconhecimento das possíveis ou atuais diferenças de opinião no mundo exterior acerca do que é certo e próprio no caso em pauta; b) uma escolha consciente de uma linha de ação em preferência a outras linhas à luz da comparação dos resultados derivados dos cursos de ação rivais; c) uma concordância em ser conhecido pelo mundo ao se identificar com o curso escolhido e seus resultados previstos e então assumir o elogio ou a culpa que propriamente couberem à escolha feita (KILPATRICK, 1941, p.28, tradução nossa).

Um dos critérios frequentemente presentes no processo de deliberação é a questão do cumprimento do dever e do respeito à autoridade externa. O terceiro estágio da identidade pessoal é o estágio em que surge a possibilidade de ruptura com a normatização.

Para Kilpatrick, uma consciência voltada para obediência à autoridade externa abre espaço para a conformação do eu integral a um status quo, diferentemente de uma consciência que se coloca a favor de uma nova moral ou moral não-tradicional.

Essa afirmação vai ao encontro da hipótese de Kilpatrick explanada anteriormente de que o senso de dever moral reflete a qualidade da cultura predominante na época e no grupo em que se encontra a pessoa. Diante dessa afirmação, Kilpatrick ressalta a importância da 
criatividade da pessoa em buscar soluções aos seus problemas, a qual é proporcional à riqueza de situações em que se envolveu e à pluralidade de pessoas com as quais se comunicou (ibidem, p.30).

Vale ressaltar que, para Kilpatrick, todo ato moral implica critérios, e o mais importante deles é o da vida digna, inclusive, se o que se quer é resistir à incorporação de um padrão moral vigente (KILPATRICK, 1941, p.30-31).

\subsection{PRINCÍPIO GERAL DA APRENDIZAGEM}

Kilpatrick afirma que a cultura, em função do processo self-other, é um fator determinante na formação das pessoas e das comunidades, que, desde a infância, percebem suas necessidades de forma cultural e, da mesma forma, elaboram seus propósitos, perseguem fins, fazem distinções e utilizam informações. O processo de elaboração interna das experiências se dá marcadamente a partir de fontes culturais de várias naturezas (KILPATRICK, 1941, p.139).

E embora a cultura possa constituir-se de padrões linguísticos, éticos ou estéticos, o processo educacional recai em cada pessoa de maneira singular. De fato, é possível que haja uma camada de semelhança entre as pessoas, um grau de uniformidade, mas, ao se analisar mais profundamente, perceber-se-á cada membro como único em algum sentido ou nível. Isso porque cada indivíduo é uma fonte única e distinta de reação ao seu ambiente, e esse fato desempenha papel determinante na formação do caráter e da personalidade. O resultado é a confluência das contribuições tanto do ambiente cultural quanto do movimento de (re)ação individual. Educação, para Kilpatrick, é isso, cujo resultado é um caráter e uma personalidade únicos (ibidem, p.139).

A aprendizagem, especificamente, é definida como um "fato observável que, de partes ou fases de uma dada experiência, [resulte e] permaneça uma, de tal modo a influenciar, [...] definitiva e necessariamente, as fases posteriores dessa mesma experiência” (ibidem, p.141, tradução nossa).

A experiência de aprendizagem, para Kilpatrick, possui três estágios, a saber: a) uma experiência vivida, um desenvolvimento criativo dentro de mim, uma apresentação para mim mesmo de uma nova fase de desenvolvimento dentro de uma situação; b) o aceite disto que está me ocorrendo; c) o que foi aceito permanece em mim, permeia e pode auxiliar numa outra experiência (ibidem, p.143).

O resultado da experiência de aprendizagem não se resume à mudança no pensar, mas também no falar, nas emoções e nos sentimentos e no agir ético. Nas palavras de Kilpatrick: 
"Em uma palavra, a pessoa entra na experiência ativa de forma inteira, por isso o resultado da aprendizagem inclui não somente pensamento, mas também sentimento, impulsos, decisões, atos corporais - qualquer um e [ao mesmo tempo] todos os aspectos da vida em si." (ibidem, p.144, tradução nossa).

Aprendizagem significa a reconstrução de conteúdos consciente e inconscientemente vivenciados. O significado de inconsciente relaciona-se tão somente àquelas conexões ramificadas de comportamento sobre as quais não se toma consciência, que também incluem pensamentos, sentimentos e impulsos, as quais se evidenciarão na ação ou na reflexão sobre si próprio.

O princípio geral da aprendizagem em Kilpatrick diz: “aprendemos o que vivemos. Aprendemos cada coisa conforme a aceitamos como nossa; e aprendemos na medida em que a consideramos importante ${ }^{9}$ (KILPATRICK, 1941, p.146, tradução nossa).

\subsection{FORMAÇÃO DO CARÁTER}

Caráter é o self cônscio formado a partir do processo self-other, ou seja, formado pelos efeitos da experiência interpenetrados como uma rede sem rupturas (ibidem, p.150).

É preciso considerar que: a) qualquer que seja a natureza do conteúdo permanente resultante da aprendizagem, esse se fixará no caráter; b) que o novo aprendizado, surgido a partir do desenvolvimento da experiência anterior, instantaneamente reintegra-se no fluxo da experiência atual de modo a permeá-la.

Desse modo, o caráter não é um agregado de experiências uma sobre as outras, como uma pilha de blocos em que um é posto sobre o topo do outro. Em vez disso, Kilpatrick considera que "cada elemento novo do caráter tal como vem é ele próprio permeado pelos elementos anteriores cuja reação os trouxe à existência, e por sua vez, como entra pertinentemente em atividade, permeia o restante do desenvolvimento da experiência." (ibidem, p.151, tradução nossa). O resultado dessas ativas relações de permeação forma uma estrutura, chamada caráter, a qual influenciará a experiência e toda a vida ulterior.

Dewey descreve como um elemento entrelaçado no caráter nele permanece fixo. Para Dewey, cada elemento novo no caráter, elemento, esse, o qual chama de hábito, acaba por operar todo o tempo enquanto o indivíduo permanece acordado. E acrescenta:

\footnotetext{
${ }^{9}$ No original: "We learn what we live. We learn each thing as we accept it to act on, and we learn it in the degree that we count it important.".
} 
não fosse pela operação contínua de todos os hábitos em todo ato, não poderia existir algo como o caráter; exitiria, sim, um feixe de atos desconexos e isolados. Caráter é a interpenetração de hábitos. [...] [Assim], um hábito não se torna arraigado ou firme por si mesmo, mas, sim, pelo reforço que recebe de outros, os quais ele absorve (DEWEY, 1956, p.40).

O caráter está em (re)construção durante tanto quanto tempo dure a vida da pessoa. $\mathrm{O}$ que é novo de cada fase sucessiva da experiência mediante a aprendizagem interconectar-se-á sempre com o antigo. Cada novo fato é imediata e diretamente interconectado com todos os antigos que, conscientemente, envolveram-se no processo, e mediata e indiretamente interconectados por meio desses elementos cônscios com as partes constitutivas do caráter com as quais esses antigos elementos conscientemente usados foram previamente conectados. (KILPATRICK, 1941, p.152).

Há um elemento intrínseco que coordena todo o processo de construção do caráter, que é o pensamento do self consciente, o qual observa o que é feito e intervém no processo de modo a assenti-lo ou negá-lo. Primeiramente, o self pondera a adequação do ato no processo para responder a qualquer fim ou interesse interno que está naquele momento preocupado em seguir. Segundo, à luz dos valores pessoais que estão envolvidos com a situação em questão, os atos são aprovados pelo self. Terceiro e finalmente, o self julga tudo a partir de seus ideais, de modo o mais impessoal possível, na medida em que esses são implicados nas consequências do ato proposto. O self agirá eticamente somente se agir a partir de seus ideais e, somente desse modo, concordará em se colocar diante dos outros como responsável e comprometido com seus atos (ibidem, p.153).

É importante notar que, para Kilpatrick, quando se diz "uma experiência”, na realidade trata-se de um feixe de experiências que incluem uma sucessão maior ou menor de experiências distintas, cada uma separada de sua predecessora e sua sucessora por experiências transitórias cuja atenção é menos ativa. Sem qualquer organização, sequer haveria um fluxo nem um feixe de experiências a serem internalizadas. Essas experiências são tomadas pelo self como um único feixe e incorporadas às experiências antigas como um fluxo pessoal, consciente de si e identitário. (ibidem, p.154).

A educação democrática do caráter baseia-se na abundância de oportunidades de se fazer decisões, de modo cada vez mais reflexivo, guiadas por uma visão larga da realidade, quando devem interagir duas coisas: primeiramente, um corpo de princípios de ação conscientemente crítico; e segundo, uma prática sistemática de decisão deliberada sobre o que fazer (ibidem, p.156). 
Kilpatrick considera que o caráter precisa ser ativo e possuir convicção, de modo que: primeiro, a pessoa deve possuir razões conscientemente defensáveis para o curso de ação proposto. Mesmo que haja mudanças contextuais no percurso da ação, a inteligência as deve guiar. Segundo, a pessoa deve estar consciente de que, ao longo da situação atual confrontada, ela possui saberes e convicções abrangentes o suficiente para dar continuidade ao que se propõe, o que exige a elaboração prévia de princípios de pensamento e ação, que englobam valores pertinentes do ponto de vista material, intelectual, estético, social e ético. Terceiro, a pessoa deve ter formado o hábito forte de ação pensada, de traduzir em ação o melhor possível de si. Em suma, um caráter ativo e convicto se define a partir desses três elementos (KILPATRICK, 1941, p.156-157).

\subsubsection{Níveis de agência moral}

A vida é uma constante interação entre organismo e ambiente. Todo indivíduo humano como uma identidade pessoal consciente de si é, pois, continuamente chamado a se ajustar mediante as condições que surgem e, muitas vezes, adaptar-se a elas. Nesse sentido, vida é sinônimo de constante reajustamento ou reconstrução de seu próprio caráter e identidade pessoal (ibidem, p.146-147).

Não raro, crianças que se recusam a encarar a realidade podem ser consideradas identidades mal adaptadas. Desde o nascimento, o ser humano encontra tanto facilidades quanto dificuldades de realização de seus propósitos. Uma educação saudável é aquela em que há mediadores que mantêm o nível do desafio compatível com o desenvolvimento da criança. O que erroneamente pode ocorrer é a ausência de desafios, cuja consequência é uma identidade inadaptada para encarar possíveis condições adversas do ambiente. Mesmo que essa criança aparentemente tenha se desenvolvido, internamente não se adaptou ao seu ambiente cultural e, então, passa a se destacar na multidão como alguém que foge ao surgimento da primeira dificuldade. Do ponto de vista moral, torna-se habituada a desconsiderar o necessário significado das consequências de seus atos, a culpar aos outros ou a queixar-se das situações, buscando realizar somente aquilo que é fácil e prazeroso, e, de acordo com esse tom, constrói sua identidade e consciência de si. Diz, Kilpatrick:

esse desajustamento em particular é muito grave, visto que atinge o ponto crucial do direcionamento ativo da vida em si. [De modo que] falhar nesse aspecto significa errar radicalmente. E o local da falha é no self, [mais especificamente] no caráter do self, até então deturpado sob pretexto de se manter a autoestima da pessoa (ibidem, p.148-149, tradução nossa). 
Em Kilpatrick, a agência moral é determinada por vários fatores, a saber: o estágio atual de desenvolvimento da agência pessoal, o nível de criticidade que envolve o senso de dever moral, o nível de desenvolvimento da responsabilidade, a qualidade da cultura predominante na época e o grupo em que se encontra a pessoa e a qualidade das experiências reflexivas compartilhadas.

Diante desse conjunto de fatores, é notório que para o autor, não há possibilidade de prefixação de estágios de desenvolvimento moral além dos estágios de desenvolvimento da identidade pessoal anteriormente descritos. O que não significa que não se possam estabelecer a posteriori parâmetros de comportamento em função de determinados fatores.

Kilpatrick (1941, p.70) exemplifica a questão ao citar uma pesquisa realizada por Jean Piaget (1932, p.275), publicada em O juízo moral na criança, onde 150 crianças de idades entre 6 e 12 anos foram questionadas acerca de algumas narrativas que foram lidas para elas.

A partir dessas narrativas, Piaget investiga o nível de desenvolvimento do senso de justiça em cada criança em função da idade e de que modo cada criança lida com o conflito interno relativo ao embate entre seu senso de justiça e a obediência à autoridade do adulto (PIAGET, 1932, p.275).

Diante do objetivo deste trabalho, é suficiente a citação de apenas uma das narrativas presentes em $O$ juízo moral na criança, a qual conta que uma tropa de escoteiros fora acampar e que cada grupo ficou responsável pela organização e execução de certas tarefas do acampamento. Um foi às compras num vilarejo próximo de onde estavam, o outro foi buscar madeira e o último limpou o local.

Enquanto cada grupo realizava o combinado, alguém percebeu que a tropa como um todo estava sem pão. Porém, àquela altura não havia o que fazer pois o grupo responsável pelas compras já havia saído. Então, o líder da tropa enviou um dos meninos que já havia terminado seu trabalho ao vilarejo para comprar pão.

Diante da atitude do líder da tropa e do menino que fora comprar pão, Piaget questionou cada criança no sentido de averiguar se ela julgava que a atitude dos escoteiros deveria ter se pautado na justiça, no caso, na equidade de tratamento, ou na obediência à autoridade do líder. Os dados encontrados por Piaget são descritos na Tabela 1:

Tabela 1 - Opinião acerca da obediência ou equidade

\begin{tabular}{ccc}
\hline Idade & Obediência $(\%)$ & Equidade $(\%)$ \\
\hline 6 & 95 & 5 \\
\hline 7 & 55 & 45 \\
\hline 8 & 33,3 & 66,7 \\
\hline 9 & 16,7 & 83,3 \\
\hline
\end{tabular}




\begin{tabular}{ccc}
\hline 10 & 10 & 90 \\
\hline 11 & 5 & 95 \\
\hline 12 & 0 & 100 \\
\hline
\end{tabular}

Piaget (1932, p.277, tradução nossa)

Piaget analisou os dados a partir de quatro critérios, por sua vez citados por Kilpatrick (1941, p.72, tradução nossa):
a) obediência é correta e justa. O líder mandou, deve-se cumprir a ordem;
b) a demanda não é justa, mas, de qualquer modo, deve-se fazê-lo, já que o chefe mandou;
c) a demanda em si não é justa e, portanto, não se deve cumpri-la;
d) a demanda considerada em si não é justa, mas, sob as circunstâncias é melhor fazer como foi pedido (KILPATRICK, 1941, p.72).

Piaget, de posse dos dados e a partir dos quatro critérios citados, considerou a existência de dois grandes grupos de crianças de modo que um é composto pela parcela de crianças mais novas, que expressaram comportamento de obediência; e o outro, formado pela parcela de crianças mais velhas, que expressaram senso de justiça mais desenvolvido.

Embora Kilpatrick desaprove a prefixação de estágios de desenvolvimento da agência moral em função da idade (ibidem, p.74) ou mesmo a ideia de estágios quando se poderia pensar em níveis, o autor não desabona a análise de Piaget sobre a questão, porém e por sua vez, a coloca em outros termos, a saber, sob a capacidade pessoal de deliberação em função da relação estabelecida entre a unidade do self e o other.

A análise de Kilpatrick a partir desse critério evidencia que para os mais novos, a aceitação da autoridade tanto em relação ao que fazer quanto ao que pensar revela uma conduta marcadamente heterônoma, visto que o processo self-other não se desenvolvera a ponto de oferecer a essas crianças qualquer base deliberativa ou de autodeterminação. Apesar de haverem progredido suficientemente na utilização da linguagem, no reconhecimento de si próprias e dos outros como pessoas ou mesmo na conduta guiada por um senso de dever moral ou um princípio de responsabilidade, por ora, essas crianças ainda não haviam desenvolvido uma criticidade moral e, consequentemente, uma autoridade interna capazes de sobrepujar a autoridade externa proveniente do líder da tropa (ibidem, p.72-73).

O segundo grupo de monstra um nível maior de apreensão das convenções sociais, visto que há a comparação mental dos papéis por meio da ação do processo self-other e um certo senso de justiça, mas o hábito condicionado à obediência prevalece na atitude externa (ibidem, p.73).

No terceiro grupo, há a instalação radical do sentido de justiça a partir de fatores mais notórios da situação narrada, visto que o processo self-other proporciona tal base, porém há 
ainda uma desconsideração dos fatores menos notórios da situação, os quais efetivamente viriam a incidir na deliberação do quarto grupo, cujo self demonstra ser mais complexo e, portanto, capaz de considerar a situação sob um número maior de critérios e de relações. Desse modo, um direito específico e isolado não seria suficiente para firmar de modo justo uma atitude, visto que esse grupo trouxe para a deliberação outros elementos tão ou mais importantes que a equidade de tratamento.

Para Kilpatrick, o nível de desenvolvimento do processo self-other é determinante na conduta moral, pois significa uma maior ou menor possibilidade de autodeterminação ética e, consequentemente, de ação responsável e de desenvolvimento do senso de dever moral reflexivo.

\subsection{O PROCESSO SELF-OTHER COMO PRINCÍPIO PARA O DESENVOLVIMENTO DA CULTURA E DAS IDENTIDADES PESSOAIS}

Kilpatrick, em Identidade Pessoal e Civilização, deu especial atenção à discussão sobre o papel da cultura nos processos onto e filogenético de individuação e de constituição da identidade pessoal.

Primeiramente, para Kilpatrick, a cultura

consiste em todos os elementos feitos pelo homem e relacionados à vida humana, [...] tudo o que foi inventado ou descoberto pelo homem e que se insere na dinâmica social. Inclui, portanto, elementos como linguagem, ferramentas, costumes, instituições, ideias, padrões [de comportamento] e ideais (KILPATRICK, 1941, p.33, tradução nossa).

Embora, segundo o autor, seja improvável que todos os membros de um grupo adquiram igualmente toda a cultura disponível, a cultura de um grupo é influenciada por todos os indivíduos, especialmente nas sociedades que possuem maior poder de comunicação.

Algumas das teses defendidas por Kilpatrick em Identidade Pessoal e Civilização que são pertinentes à proposta deste trabalho são as que versam sobre o desenvolvimento e a transmissão da cultura, o processo gradativo de individuação e de formação das identidades pessoais e o papel das instituições na formação dessas identidades. Eis as teses:

a) historicamente, o desenvolvimento da cultura se deu reciprocamente com o desenvolvimento de identidades pessoais cada vez mais complexas. Cada qual, cultura e identidade pessoal, quando formada, influenciou a outra no sentido de se tornar mais bem definida e completa;

b) a participação ativa na vida em grupo é o principal meio de transmissão da cultura de uma geração para a seguinte e do grupo para o indivíduo. E a participação na sua transmissão constitui o principal meio para os processos de individuação e formação identitária; 
c) somente por meio de lentos e dispersos avanços o ser humano pôde alcançar a compreensão e a distinção necessárias ao desenvolvimento do comportamento individualizado;

d) a cultura pode, em um sentido real e específico, ser definida como inteligência comunicável. Nesse sentido, inteligência vem sendo construída para a vantagem dos indivíduos e do grupo e em função das necessidades; [...] (ibidem, p.35, tradução nossa).

A partir dessas teses, o autor desenvolverá sua argumentação com vistas a explicitar a interdependência ontológica entre identidade pessoal e cultura e entre indivíduo e sociedade.

\subsubsection{O processo histórico de complexificação da cultura e das identidades pessoais}

A complexificação da cultura é onto e filogeneticamente concomitante à complexificação das identidades pessoais, sendo uma a causa e o efeito da evolução da outra; evolução, essa, ininterrupta e não necessariamente progressiva no sentido da dignidade humana.

A espécie humana destacou-se dentre as outras espécies pelo uso de ferramentas e pela linguagem. Esses dois elementos, juntamente com o processo de individuação, agiram reciprocamente no processo evolutivo, de modo que o desenvolvimento de qualquer elemento cultural, inclusive o uso de ferramentas, foi profundamente influenciado pela presença da linguagem. A exemplo do macaco que aprendeu a pegar a banana alçando-a com uma vara e seus companheiros, por conta da ausência de comunicação simbólica, não puderam compartilhar dessa aprendizagem e, desse modo, não houve aquisição do uso padronizado dessa ferramenta pelo grupo, ou seja, não houve a assimilação pelos indivíduos de um novo padrão cultural. Como resultado, não desenvolveram cultura, linguagem simbólica ou individualidade (KILPATRICK, 1941, p.35-39).

Kilpatrick revisita Dewey ao afirmar que "a linguagem é a mãe cuidadora de todo significado" (DEWEY, 1929, p.186) e que “eventos quando uma vez que são nomeados, levam uma vida dupla e independente" (ibidem, p.166).

Consoante à essa ideia, Kilpatrick corrobora a interdependência da cultura tanto em relação à linguagem quanto à vida em grupo, visto que, para o autor, os eventos, mesmo sem haverem sido nomeados, continuam a ser eventos dentro de séries causais; porém, quando nomeados, passam a ter, em função da natureza da linguagem e da capacidade cognitiva humana, um novo tipo de existência que se manifesta na comunicação e no pensamento simbólico, os quais, por sua vez, seguem a dinâmica self-other e permitem que tais eventos possam ser imaginados e então rearranjados. De todo modo, conclui Kilpatrick, somente a vida 
em grupo possibilita a existência e compartilhamento interpessoal dos significados da realidade vivenciada individualmente (KILPATRICK, 1941, p.37).

O uso da linguagem para a comunicação e para o pensamento resulta na possibilidade de ampliação da dinâmica self-other e, consequentemente, das possibilidades de cooperação dos e entre integrantes de um grupo. Em qualquer circunstância, os signos tornam-se o principal meio de efetivação dessas cooperações, quando "cada cooperante deve compreender a empresa comum tanto quanto o papel de cada um [dos indivíduos] durante o esforço mútuo" (ibidem, p.37, tradução nossa, itálico do autor).

Por sua vez, a cooperação e o compartilhamento de significados, possibilitados pela linguagem e pelo processo self-other, abriram terreno para que se ampliasse o desenvolvimento tecnológico, o que ocasionou, em última instância, a complexificação tanto da vida humana quanto de seu significado.

Kilpatrick afirma que as ferramentas, surgidas da necessidade coletiva, enquanto auxiliam no trabalho, impulsionam transformações no relacionamento econômico e interpessoal. E, ao mesmo tempo em que trazem soluções, criam dificuldades. Haja vista o quão drásticas foram as transformações provocadas pela máquina a vapor durante a Revolução Industrial, ou o quão influentes são os artefatos tecnológicos no modo com o qual a sociedade se organiza (KILPATRICK, 1941, p.38).

Artefatos tecnológicos cada vez mais complexos tendem a trazer novas demandas éticas, econômicas e sociais ao ser humano, que, em as havendo superado, não retorna ao nível inicial de organização da vida, mas, põe-se a imaginar um mundo novo com outros artefatos ainda mais complexos.

\subsubsection{A interdependência indivíduo-sociedade no que tange à moral e à crítica à cultura}

O processo de individuação e de formação da identidade pessoal da criança se dá, como visto anteriormente, por meio de um processo de discriminação dos elementos do ambiente e dos sons que os designam. Esse processo ocorre na vida em grupo no ambiente de origem da criança e é determinante para a vida que se sucede e que se dá em um universo social cada vez maior.

A linguagem possibilita ao indivíduo seu desenvolvimento identitário por meio da apropriação da cultura pelo self. Nesse fato reside a explicação das diferenças de costumes e de preferências quando se comparam diferentes etnias, diferenças, essas que, segundo Kilpatrick 
(1941, p.41, tradução nossa), têm sua origem na pluralidade cultural e não em aspectos biológicos inatos, ou seja, em certa medida, "a cultura molda a criança ao seu modo".

Os padrões identitários atuais são o resultado do permanente processo de transformação e complexificação tanto da cultura quanto da natureza das relações interpessoais de milhares de anos. Isso significa que a possibilidade de existência de padrões pessoais de comportamento é o resultado de uma extensa série de processos históricos.

Do ponto de vista moral, é notório que para um certo grupo, há elementos culturais e comportamentais que são mais bem aceitos do que outros. Porém, as inevitáveis diferenças que surgem entre os grupos exigem que se estabeleça uma conscientização de cada grupo no sentido de proporcionar uma vida digna a todos os seus membros. É nesse sentido que Kilpatrick afirma que a melhor sociedade "é aquela em que cada pessoa conscientemente sente-se obrigada a respeitar igualmente os direitos e sentimentos dos outros" (KILPATRICK, 1941, p.42, tradução nossa).

Há, pois, um padrão mínimo de comportamento para que esse nível de consciência seja não somente alcançado, mas superado. Em poucas palavras, esse padrão pode ser explicitado por meio do contraste entre um self inclusivo e um self excludente ${ }^{10}$.

Para Kilpatrick (1941, p.42), agir conforme o self inclusivo significa enfaticamente incluir o other nas tomadas de decisão; em contrapartida, o self excludente significa a exclusão consciente desse other nas e das tomadas de decisão. Porém, apesar de haver um espectro ético, estético, político e afetivo de agência individual cujos limites são o self excludente e o self inclusivo, essa agência se dará em função do embate entre os diferentes “eus”, conforme James (2007, p.309).

Do ponto de vista histórico, é notório como a moral predominante no grupo influenciou a formação da agência individual e vice-versa, de tal modo e com tal poder que, em certo momento da história, foi possível ao ser humano espantar-se consigo próprio.

Kilpatrick começa citando os antigos egípcios, que, por exemplo, acreditavam que diante da morte do corpo físico, conforme descrito no Livro da Morte, a alma seria examinada e, então, ganharia determinando destino no além segundo o nível de justiça praticado em vida para com todos, independentemente da casta social de origem.

Evidentemente, a noção de identidade pessoal difundida no século XX não é análoga à difundida entre os antigos egípcios, tampouco é circunscrita à noção de status social. Porém, não se pode negar que, de fato, o conteúdo da crença religiosa descrito por Kilpatrick era afetado

\footnotetext{
${ }^{10}$ Originalmente denominado por Kilpatrick (1941) como broad self e narrow self, respectivamente.
} 
por dois processos: um, de compartilhamento cultural e, outro, de individuação, já que a conduta de cada pessoa, em certa medida, tanto refletia a cultura do grupo quanto refletia inclinações de caráter pessoal. Desse modo, a conduta pessoal era permeada por valores, logo, deveria ser objeto da ética dos egípcios (KILPATRICK, 1941, p.44).

Segundo Kilpatrick (1941, p.44), a ética presente na cultura egípcia relativa à justiça igualitária produziu reverberações entre os babilônicos e, então, na Palestina. Embora os primeiros hebreus, diferentemente dos egípcios, mantivessem seu código moral centrado na tribo, o conteúdo da "Parábola do Bom Samaritano" reflete a ética dos egípcios.

Cerca de dois mil anos depois dos egípcios, Platão também argumentaria sobre a moral inerente à conduta pessoal.

A proposta de Kilpatrick está aquém de uma análise detalhada do pensamento platônico e mesmo sobre o quanto o pensamento platônico fora influenciado pelo pensamento egípcio; porém, Kilpatrick faz alusão ao diálogo platônico Teeteto como forma de exemplificar a presença da temática egípcia na obra platônica (KILPATRICK, 1941, p.45).

Kilpatrick também faz alusão à tradição cristã, que enfatizou o valor supremo do indivíduo humano e que, por sua vez, fora fundada nas contribuições dos hebreus e dos gregos, cujo pensamento moral, segundo Kilpatrick, tivera base não somente nos egípcios, mas também nos indianos e nos babilônicos (ibidem, p.45).

Se os egípcios contribuíram historicamente para a transformação da visão moral, os gregos, por sua vez, ofereceram nada menos que uma nova dimensão ao pensamento, tamanha fora sua contribuição. Anteriormente ao pensamento grego clássico, os grupos eram suficientemente organizados para apenas dar continuidade à sua tradição, visto que os indivíduos careciam da mínima de consciência de si para uma avaliação crítica de suas crenças.

Kilpatrick afirma que foi somente a partir do pensamento grego clássico que fora possível um movimento de autoconsciência e mesmo de autocrítica culturais. Isso em função do confronto intercultural propiciado por sua expansão territorial e pela guerra contra os persas, as quais em certa medida exigiram reflexão sobre a alteridade. $\mathrm{O}$ other, em função desse contexto, tornar-se-ia mais evidente. E então, o espanto diante do outro provocaria o espanto diante de si próprio (ibidem, p.46).

Nesse ínterim, fixaram-se questões fundamentais: por que penso o que penso e como penso (ibidem, p.46).

Kilpatrick (1941, p.47) comenta:

Tal foi a glória da Grécia Clássica. Depois da linguagem [humana] em si, essa realização dos gregos [referente à crítica da cultura] marca o maior avanço 
intelectual já feito pelo homem. Nele, a personalidade humana avançou surpreendentemente. Talvez, muitos entre nós concordam com a afirmação de Sir Henry Maine (1822-1888) [, a saber]: 'Exceto as forças ocultas da natureza, não há nada que se mova nesse mundo que não seja grego na origem'.

De fato, a inteligência do mundo ganhou uma nova dimensão, tanto em relação ao volume e à qualidade do saber produzido quanto à capacidade de crítica à própria cultura. Tanto é que, segundo Kilpatrick, se passariam dois mil anos até que o pensamento desse outro passo de mesma dimensão, e esse fora dado, segundo o autor, por Galileu e o pensamento experimental, o qual se estende até os dias atuais e que embasa a educação defendida pelo autor.

Em suma, segundo Kilpatrick, evidencia-se historicamente que, de fato, por meio do processo self-other a civilização pode desenvolver de modo interdependente a tecnologia, a cultura, a linguagem, a inteligência e a individualidade.

Durante todo o processo de evolução, do advento da espécie aos dias atuais, um grande salto no desenvolvimento cultural ocorrera com a tentativa de tratamento igualitário entre as pessoas, cuja essência motriz subjaz nas crenças religiosas da época e posteriormente na própria democracia moderna. Séculos depois das civilizações hebraica e egípcia, os gregos desenvolveriam a habilidade e a disposição de, conscientemente, criticar a própria cultura; crítica, essa, que, mais tarde, conduziria o ser humano ao desenvolvimento de métodos científicos e filosóficos de investigação e de pensamento.

Quando, na modernidade, a aceitação do conhecimento advindo do método experimental conduziria o ser humano a considerar esse método como forma de se pensar a própria vida.

Vale ressaltar que, para Kilpatrick, o desenvolvimento do mundo social e do mundo pessoal, da cultura e das identidades pessoais, ocorrem simultânea e correlativamente na história por meio do princípio self-other, de modo que um significa a possibilidade de existência da outro (KILPATRICK, 1941, p.49-50).

\subsection{INDIVIDUALIDADE}

Em Kilpatrick, identidade pessoal e individualidade assumem significados diferentes. A primeira, tratada anteriormente, denota um estado de profunda e ativa consciência de si, consciência daquilo que na e segundo a pessoa, a torna quem ela é, ao mesmo tempo que a faz projetar-se no futuro em função de suas motivações e preferências do presente. A individualidade, por sua vez, marca por meio de um movimento de distinção em relação ao 
other o limite entre aquilo que a caracteriza e aquilo que não lhe é próprio; em certa medida, trata-se de um esforço em encontrar o que a distingue do other. A individualidade possui quatro característica, a saber:

a) a ideia de singularidade - não haverá duas individualidades exatamente iguais; b) a ideia de auto-determinação - individualidade precisa de algum modo construir-se e agir por si própria; c) a ideia de padrão, que descreve e define a conduta individual, não o mesmo padrão para todos - longe disso mas um padrão reconhecidamente consistente o qual fornece a singularidade desejada; d) o fator self-other, para que a individualidade não somente crie a si própria verdadeiramente, mas para que também saiba como seus padrões diferem dos padrões de outros e porque e então deseja o resultado diante do mundo (ibidem, p.191, tradução nossa).

A partir da noção de democracia em Kilpatrick, tratada anteriormente, a individualidade implica respeito e valorização pessoal mútuos, com o intuito de que tanto a individualidade quanto a identidade pessoal sejam suscitadas a autenticamente expressar-se num regime de liberdade. Nesse sentido, Kilpatrick compreende sociedade democrática, individualidadeidentidade pessoal e liberdade como elementos imbricados e interdependentes. Desse modo, a noção de liberdade em Kilpatrick assume notória importância, e, em virtude dessa importância, será explanada no item que segue.

\subsection{LIBERDADE}

Kilpatrick, em Identidade Pessoal e Civilização, explana quatro significados de liberdade e suas implicações para a conduta moral e para a educação, que são: liberdade como autodeterminação; liberdade vista sob o princípio universal de causa; liberdade em função do preconceito; liberdade efetiva por meio de formas institucionais próprias.

\subsubsection{Liberdade como autodeterminação}

A liberdade como autodeterminação é explanada por Kilpatrick em seu sentido pessoal e ético, de modo a relacioná-la ao aspecto intencional da pessoa em não apenas fazer algo, mas em fazê-lo de modo conexo à consciência sobre as circunstâncias e os resultados previstos (KILPATRICK, 1941, p.166).

Para Kilpatrick, o agir ético implica dever moral reflexivo e responsabilidade, que são condições cuja possibilidade de existência se dá na dinâmica self-other. Diz, Kilpatrick (1941, p.167, tradução nossa): 
quando, portanto, uma pessoa aprende a planejar e a dirigir sua vida de maneira pensada, a par dos direitos e sentimentos dos outros, ela está, na mesma medida, demonstrando uma autodeterminação ética. [...] [E como tal], na medida em que ela pensa sobre o que faz, aceita a conduta com sua. Identifica-se com ela. Admite voluntariamente para si própria e para os outros que ela, pessoa, é - ou se propõe a ser - o tipo de pessoa que realiza tais atos. A habilidade e disposição para agir como tal implica um tipo de liberdade, [visto que,] para engajar-se em tal autodeterminação é preciso ser livre eticamente.

Por outro lado, embora a autodeterminação ética implique propósito por parte de quem age, a inclinação por um tipo de conduta, a responsabilidade e o dever moral que acompanham o ato fazem com que esse tipo de liberdade esteja associado também aos resultados não intencionados (ibidem, p.167). Desse modo, o valor moral da ação não está somente no que fora proposto e nos prováveis resultados da ação, mas também no desejo pessoal de os resultados sejam alcançados e na própria reflexão sobre como alcançá-los. A habilidade de intencionar eticamente, no sentido posto, depende de uma individualidade que se constituiu de maneira adequada e de forma intencional em relação ao próprio processo de formação. É nesse sentido que Kilpatrick afirma que a individualidade-identidade pessoal deve ser livre para autodeterminar-se, quando o self é intencionalmente agente e paciente.

No que concerne à educação, deve-se considerar que o educando, em marcha de desenvolvimento, necessita ser levado tanto pelos educadores quanto pela família a pensar antes de agir e a aprender com os resultados de seus atos. A formação autodeterminante do senso reflexivo de dever moral, que implica o exercício de agir deliberadamente, contribui para que se efetive progressivamente a liberdade e, desse modo, a autodeterminação ética da pessoa.

\subsubsection{Liberdade vista sob o princípio universal de causalidade}

Neste tópico, o autor traz para discussão as implicações éticas para o que é conhecido por "lei de causalidade". Kilpatrick, nesse ponto, não está preocupado em discutir formalmente a lei de causalidade. Tão apenas almeja trazer à tona um princípio cuja "influência no passado fora difundida particularmente entre estudantes das ciências naturais e aqueles que aceitaram a ciência natural como modelo para a psicologia e para as demais ciêcias humanas (KILPATRICK, 1941, p.170, tradução nossa). Portanto, o autor visa a explicitar os resultados dessa influência não somente para o campo da psicologia, mas também para o campo da educação.

O argumento favorável à causalidade pode ser sintetizado conforme o que segue: 
não é verdade que todos os fenômenos da natureza, incluindo o comportamento do homem, são regidos pela 'lei do reino natural'? Especificamente, não é 'a lei de causação' tão universal e tão inclusiva que todos os atos de cada homem indivídual são tão completamente determinados como são os dos tijolos ou os das mariposas e que o homem, por consequência, não é, de fato, mais livre que eles, mas somente diferente, como o comportamento do gato é diferente do comportamento canino e a ação do hidrogênio é diferente da ação do oxigênio (ibidem, p.169, tradução nossa)?

Em suma, o que está em questão é o questionamento sobre se a liberdade humana seria mera ilusão. Kilpatrick apresenta duas respostas a esse questionamento, conforme será exposto nos parágrafos que seguem.

A primeira vai ao encontro da análise do comportamento humano sob a perspectiva da lei de causalidade. Poder-se-ia pensar: se pela lei universal de causalidade todos os eventos e resultados que se sucederão de agora em diante são dados a priori pelas "leis da natureza", portanto, esses resultados estão prescritos na linha do tempo e as próprias escolhas do homem são dadas da mesma forma. Ou seja, tanto a escolha de se esforçar quanto o próprio esforço realizado pelo homem, justificável em função das melhorias que proporciona à vida, são naturalmente dados a priori.

É notório como essa ideia cria um lapso nas crenças de cada pessoa sobre si própria e no próprio sentido da vida. Porém, a concepção do comportamento humano a partir desse princípio não se mostrou profícua, e Kilpatrick dá o exemplo por meio de duas situações cotidianas.

A primeira descreve a uma cozinheira que, diante da tarefa de servir o jantar na hora certa, tem plena consciência de que se não iniciar os preparos com antecedência, o jantar não estará pronto segundo o combinado. A segunda situação refere-se, ironicamente, aos cientistas newtonianos que, a despeito da lei de causalidade, sabem que se os experimentos não forem planejados e deliberadamente supervisionados, os resultados serão diferentes daqueles que se obteriam mediante planejamento e supervisão.

Apesar da discordância do autor em relação à aplicação cega dos princípios da física para a compreensão do comportamento humano, o autor não argumenta no sentido de invalidar tais princípios. Em vez disso, Kilpatrick estabelece uma relação coerente entre as leis da física e o comportamento ético. Diz, o autor:

a ciência descobriu certas uniformidades na natureza (frequentemente chamadas "leis") as quais o ser humano utiliza para seu desenvolvimento. Quanto mais o homem intera-se dessas uniformidades, maiores são as chances de se encontrar caminhos apropriados aos seus fins. Nesse caso, saber é poder. Em outras palavras, quanto mais o homem conhece, maior é liberdade com a 
qual realiza seus propósitos. As leis da natureza tornam-se, desse modo, meios para a liberdade (KILPATRICK, 1941, p.172, tradução nossa).

Porém, segundo Kilpatrick, o equívoco na aplicação irrestrita de princípios da física aos estudos do comportamento ético surge da intenção de tornar absolutas leis que são condicionais, ou seja, que dependem de certas condições para serem replicadas e atingirem os mesmos resultados. Em suma, essas leis constituem o chamado determinismo cósmico, segundo o qual todas as coisas e todos os eventos, em todos os detalhes, foram prefixados desde o começo no universo.

Contudo, há outra hipótese, relativa um determinismo específico ou local, segundo o qual "vivemos em um mundo de novidades realmente emergentes, onde os resultados dos eventos são [, aos nossos olhos,] contingentes, embora em cada detalhe a natureza aja com uniformidades confiáveis." (ibidem, p.174, tradução nossa).

Segundo essa hipótese, esforço e responsabilidade não somente fazem sentido como são extraordinariamente importantes, sendo que a cada descoberta científica, o homem torna-se mais livre para controlar o curso da história de acordo com fins conscientemente escolhidos. E mesmo para aqueles que declaram a primeira hipótese como a mais plausível, o fazem em função de descobertas científicas que demandaram experimentos e esforços que retratam a hipótese da contingência, que considera o mundo ainda não determinado.

Sobre a deliberação pessoal, pautada na hipótese da contingência, Kilpatrick remonta ao pensamento deweyano quando afirma que a escolha é produto de um processo de deliberação, cuja essência consiste na suposição das prováveis consequências de várias alternativas pertinentes, sendo que todas as conjecturas realizadas durante o processo de deliberação são constituídas pela experiência entre elementos atuais e elementos resultantes de experiências anteriores, sendo que os elementos antigos agem como fatores determinantes na escolha. Nesse sentido específico há, sem dúvida, causalidade, porém de modo não absoluto.

\subsubsection{Liberdade $x$ preconceito}

Por atitude preconceituosa entende-se que alguém assumiu uma posição sem pensamento crítico, ou ao menos sem pensamento crítico até o ponto em que o preconceito age. Significa que o pensamento estacionou em determinado nível e não busca acompanhar o desenvolvimento dos fatos. Nesse sentido, Kilpatrick busca avaliar em que medida o preconceito afeta o pensar e o aprender e, consequentemente, a liberdade de ação. 
Agir inteligentemente significa conhecer tanto as fraquezas quanto a potencialidade de uma opinião ou de um princípio e saber até que ponto é seguro confiar em tais afirmações e, se se acredita ser importante pensar antes de agir, esse pensar deve ser suficientemente específico em cada contexto (KILPATRICK, 1941, p.177).

Agir preconceituosamente significa desconsiderar o estado atual da situação e as possíveis novidades que poderiam mudar o curso da ação. Como resultado, o agente é conduzido por concepções do passado. Assim, na mesma proporção em que o preconceito se mantém presente e ativo, a pessoa manter-se-á enclausurada em si própria. Do contrário, a pessoa é livre na mesma proporção em que decide seu curso de ação por ela mesma e o faz não segundo capricho ou preconceito, mas sob mérito do caso examinado cuidadosamente (ibidem, p.178).

A liberdade de pensar possui três componentes que convergem no intuito de possibilitar um agir pensado. O primeiro é o pensar sem interferência de preconceitos ou de qualquer hábito que limite a qualidade desse pensar. O segundo é a liberdade política e social de pensar e decidir por si próprio, que é constituída genericamente tanto pelas atitudes das pessoas dentro de um contexto cultural quanto por seus direitos políticos, também peculiares a esse contexto. $\mathrm{O}$ terceiro é uma filosofia que cada um traz consigo e que se faz presente no intuito de tornar o pensamento autônomo e que proporciona uma mais acurada individualidade.

Acerca da possibilidade de superação dos preconceitos, Kilpatrick afirma que desde a infância até a idade mais avançada, a reflexão e a aprendizagem influenciam-se mutuamente, de modo que cada pessoa possui a tarefa de transformar o conteúdo inadequado das aprendizagens em novas formas adequadas de pensamento. Essa constante reconstrução da experiência opera de forma a proporcionar uma progressiva autoconsciência e autodeterminação. Seja em face da tentativa de superar os limites do autoconhecimento ou do conhecimento do ambiente, o desejo de constantemente reconstruir o significado das coisas é salutar, pois leva a pessoa a um estado cada vez maior de liberdade espiritual, e por que não a um estado de felicidade e a uma forma individual de pensar, o que se chama de uma filosofia própria (KILPATRICK, 1941, p.180).

\subsubsection{Liberdade por meio das instituições}

Exercer a liberdade por meio das instituições significa promover arranjos institucionais que possibilitem aos indivíduos de um grupo organizar-se conjuntamente na busca pelo bemestar comum. Primeiramente, é preciso que haja três elementos: uma individualidade adequada 
ao viver bem e crescer melhor; a contraparte externa na promoção do bem-estar, que vai além de somente os elementos essenciais de sobrevivência; e instituições sociais ajustadas para suprir essas necessidades e para regular adequadamente a vida coletiva. Em segundo lugar, é preciso suporte cultural consonante a esse fim, sendo que as instituições se encarregarão da difusão dessa cultura. Esse é o caminho para uma liberdade institucional efetiva (ibidem, p.181-182).

Nesse ínterim, é preciso se perguntar: até que ponto a atual cultura interage com a individualidade de modo que, por um lado, continuamente alarga, refina e integra os selves realmente em processo, e por outro, continuamente provê maior liberdade de expressão desses selves, como citado anteriormente? Por exemplo, quais os limites dentro dos quais trabalhadores dos mais variados ramos são livres para viver o tipo de vida que gostariam? Ou ainda: a quais transformações deveríamos almejar e quais espíritos deveriam ser cultivados para que sejam institucionalmente oferecidas oportunidades de livre expressão (ibidem, p.182-183)?

Kilpatrick afirma que numa sociedade democrática, diferentemente do que ocorreria num regime autoritário, há um efeito educativo na participação final no governo, assim como há o fortalecimento do autorrespeito pela individualidade; e com o poder supremo localizado nas pessoas, essas têm o direito de preservá-lo. Em uma sociedade democrática, a individualidade encontra esse caminho aberto para se desenvolver (KILPATRICK, 1941, p.186).

Considerando os casos em que a liberdade é cerceada por necessidades econômicas, torna-se evidente que as condições básicas de vida são o ponto inicial do estabelecimento de um regime de liberdade e de um sistema econômico que possibilite pleno desenvolvimento das capacidades pessoais do autorrespeito e do fortalecimento da identidade pessoal.

Em tom crítico, Kilpatrick ressalta a importância da imprensa do ponto de vista ético, político e intelectual para a formação das identidades. Diz, o autor, sobre os jornais:

em vez de contar a verdade de modo imparcial e buscar, por meio de um
comentário editorial, uma melhor explicitação da ideia, eles propagam a
verdade distorcida e escrevem editorialmente de forma tendenciosa e
preconceituosa. Tais jornais, degradando tanto quanto efetivamente podem as
mentes e almas de seus leitores, pecam não somente contra aqueles que
difamam, mas, sobretudo, pecam contra o bem comum (ibidem, p.188,
tradução nossa).

Para o autor, a imprensa como instituição deve incorporar os mesmos princípios que regem a liberdade das pessoas: do ponto de vista cultural, colocando-se, criticamente, em uma posição além do preconceito; do ponto de vista ético-político, colocando-se a favor do bem comum; do ponto de vista subjetivo, colocando-se a favor do fortalecimento das identidades pessoais. 


\section{CONSIDERAÇÕES FINAIS}

Como foi dito, este trabalho visou à exposição da filosofia da educação de William Heard Kilpatrick, buscando, primeiramente, identificar o núcleo, os princípios e paradigmas e, então, averiguar de que modo esses elementos mantiveram-se relevantes para o autor ao longo de sua trajetória intelectual. Em segundo lugar, buscou-se averiguar de que modo esses princípios e paradigmas manifestaram-se em seu pensamento sobre a educação e a democracia.

O âmago da obra de Kilpatrick é tributário do pensamento de Charles Darwin, particularmente de A descendência do homem e a seleção em relação ao sexo e A origem das espécies, de modo que a herança darwiniana manifesta-se no pensamento de Kilpatrick principalmente sob a forma do princípio da mudança permanente da natureza, no bojo do qual engloba os conceitos darwinianos de evolução, de interação organismo-ambiente e de autopreservação pela adaptação.

Enquanto princípio, a mudança permanente revela-se em Kilpatrick no conteúdo de seu pensamento filosófico, pedagógico e psicológico.

Do ponto de vista filosófico, a mudança está presente quando, a partir do conceito de experiência, os pragmatistas estabelecem a contingência como princípio em vez do prédeterminismo. A mudança também se manifesta na abordagem da relação indivíduo-sociedade e na corolária defesa da democracia como forma de vida. A democracia, em Kilpatrick, é sinônimo de possibilidade de promoção da vida digna, cujo ponto nevrálgico é relação ética indivíduo-sociedade, relação, essa, nuclear também na discussão acerca da relação entre educação e democracia.

Em relação ao pensamento pedagógico, o elemento da mudança é presente em Kilpatrick desde a discussão sobre didática, enfaticamente realizada na perspectiva do método de projeto, até a discussão sobre o currículo, quando é levantada a questão sobre prefixação do conteúdo.

$\mathrm{Na}$ discussão referente às teorias da psicologia, a mudança é presente na abordagem sobre processos de aprendizagem, na argumentação sobre as tendências de mudança da civilização moderna e na argumentação sobre as necessárias transformações culturais para que seja superado o descompasso entre o ritmo de mudança material e o espiritual ocasionado por essas tendências.

Ao partir do conceito darwiniano de interação organismo-ambiente, o pragmatismo entende a ruptura indivíduo-sociedade como insustentável do ponto de vista filosófico. Dewey, 
pautado em Darwin, no conceito de experiência e no princípio de continuidade, também foi de encontro a essa ruptura.

Esse movimento crítico da ruptura indivíduo-sociedade dos ponto de vista ético e político é elemento central no pensamento de Kilpatrick, o que procuramos evidenciar neste trabalho.

Essa crítica, em Kilpatrick, pode ser notada em função de alguns elementos-chave, como o conceito de educação, de pedagogia, de democracia, de indivíduo e a sua defesa pela não prefixação absoluta de conteúdo no currículo escolar.

De uma definição mais abrangente de educação, como a que define educação como processo de reconstrução e reorganização da experiência com vistas a ampliação de significados, Kilpatrick deduz sua própria definição de educação e a reelabora de modo a explicitar o elemento comportamental do indivíduo.

Em Educação para uma Civilização em Mudança, por exemplo, têm-se educação como processo pelo qual se adquire modos de comportamento, como crenças, tendências e modos de reação.

Por sua vez, a educação, em Identidade Pessoal e Civilização, é vista como a confluência das contribuições tanto do ambiente cultural quanto do movimento de ação e reação individual, cujo resultado são o caráter e a personalidade singulares.

Diante de ambas as definições, são notórios três aspectos: primeiro, a mudança do comportamento como meio e fim do processo de aprendizagem; segundo, a dinâmica do comportamento vista como elemento intrínseco à dinâmica do ambiente, o que torna a aprendizagem um processo único e singular; terceiro, diante de ambas as definições, na segunda houve a valorização da componente ambiental no processo de aprendizagem.

Do ponto de vista pedagógico, constatou-se um pensamento que visa a integração indivíduo-sociedade principalmente em relação ao aspecto didático, ou seja, o ensino segundo o método de projeto.

A democracia, por sua vez, é definida como a possibilidade do desenvolvimento e da expressão de cada pessoa de tal forma que, da própria expressão, resulte simultaneamente o desenvolvimento e a expressão de todos os membros do grupo ou da sociedade. Para Kilpatrick, ninguém capaz de expressar-se deve ficar à margem. Segundo essa definição, em termos éticos e políticos, a relação indivíduo-sociedade é compreendida a partir de sua continuidade, segundo a qual cada membro é constituído e constituinte em relação ao todo social.

Diante das consequências do desgovernado processo de industrialização por que passava os Estados Unidos, Kilpatrick, em Educação para uma Civilização em Mudança, 
afirma que uma das tendências daquela sociedade é a de integração social movida principalmente pela dependência econômica entre as pessoas.

Juntamente com a integração social e a ampliação do poder de comunicação, veio a obsolescência de muitas profissões - e a consequente substituição dos trabalhadores pela máquina -, a atomização social e a perda do poder político de se posicionar perante os demais. Esse cenário provocou a reação de muitos intelectuais e educadores, dentre eles, Kilpatrick, que buscou, nessa obra, argumentar em defesa da promoção de uma educação que valorizasse o sentimento de pertencimento e de respeito mútuo entre as pessoas, de modo a superar a fragmentação ética e política entre indivíduo e sociedade que vinha ocorrendo.

Ainda sobre a relação indivíduo-sociedade, do ponto de vista ético-político, Kilpatrick lança mão da discussão do conceito de autoridade, o qual é posto em pauta a partir de seus extremos, a saber: autoridade interna e externa. A primeira, como foi dito, refere-se ao dever moral reflexivo, a segunda, ao dever moral imposto pela tradição ou pela coerção. Kilpatrick afirma que a autoridade interna é digna da democracia como modo de vida moral, a segunda, dos regimes autoritários.

Até Fundamentos do Método, Kilpatrick reconhecia a continuidade inerente na relação entre cada indivíduo dentro do grupo, continuidade, essa, de caráter moral, afetivo, político, cultural, linguístico e econômico. Porém, sua proposta pedagógica enfatizava a aquisição pelo indivíduo de respostas frente ao ambiente, e esse entendido de forma reducionista, ou como uma espécie de "fonte de estímulos" para que se efetivasse o arco estímulo-resposta. Como foi ressaltado neste trabalho, nessa obra, Fundamentos do Método, Kilpatrick parece inaugurar o que fora um longo processo de mudança intelectual qualitativa sobre a relação indivíduo-grupo. Processo, esse, que teria seu apogeu em Identidade Pessoal e Civilização, cuja argumentação gira em torno não somente de uma relação indivíduo-sociedade pautada no tempo presente, mas vista sob uma perspectiva histórica da evolução da espécie humana e da construção das identidades pessoais, dadas sob o processo self-other.

E, em suma, admite-se como verdadeira a afirmação de que Kilpatrick, ao longo da vida, realizara um movimento teórico ao encontro da integração indivíduo-sociedade, tendo em vista sua crítica ao behaviorismo, a argumentação em relação à ruptura do paralelismo mente-corpo, a abordagem crítica sobre a psicologia vista sob o paradigma newtoniano e a educação, a cultura e a identidade pessoal pensadas a partir do self meadiano. 


\section{REFERÊNCIAS}

ANDRADE, E. N. F. de; CUNHA, M. V. da. O discurso pedagógico de John Dewey. Revista Brasileira de Educação, Rio de Janeiro, v. 18, n. 53, p.339-494, abr. 2013. Disponível em: <http://www.scielo.br/scielo.php?script=sci_arttext\&pid=S1413-24782013000200006>. Acesso em: 02 maio 2019.

ASSIS, R. M. de; CAMPOS, R. H. de F; LOURENÇO, É. Lourenço Filho, a escola nova e a psicologia. In: LOURENÇO FILHO, Manoel Bergström. Introdução ao estudo da escola nova. 14. ed. Rio de Janeiro: Eduerj, 2002. p. 15-53.

BEINEKE, J. A. And there were giants in the land: the life of William Heard Kilpatrick. New York: Peter Lang, 1998. 500 p. (History of Schools and Schooling. Vol.5).

BIN, A. C. Concepções de conhecimento e currículo em William Heard Kilpatrick e implicações do método de projeto: implicações do método de projeto. São Paulo: Feusp, 2012. Dissertação de mestrado.

CASAGRAnde, C. A. G. H. Mead e a educação. Belo Horizonte: Autêntica, 2014. 127 p. Coleção Pensadores e educação.

COSTA, R. A. da. Os elementos constituintes e as características da concepção de experiência na obra de John Dewey. 2016. 130 f. Dissertação (Mestrado). USP: São Paulo, 2016.

CREMIN, L.A. The transformation of the school: Progressivism in American Education, 1876-1957. Vintage Books Edition: New York, 1964.

DEWEY, J. A criança e o programa escolar. São Paulo: Abril Cultural, 1980a. (Os pensadores). Tradução de Anísio S. Teixeira. Original: (The child and the curriculum).

DEWEY, J. A natureza humana e a conduta: introdução à psicologia social. Bauru: Brasil S.A., 1956. Trad. Eugênio Marcondes Rocha e Jacob Thealdi. Original: (The human nature and the conduct)

DEWEY, J. Como pensamos: como se relaciona o processo reflexivo com o processo educativo. 4. ed. São Paulo: Ed. Nacional, 1979a. 292 p. (Atualidades pedagógicas). Tradução de Haidée Camargo Campos.

DEWEY, J. Democracia e educação: introdução à filosofia da educação. 4. ed. São Paulo: Ed. Nacional, 1979b. 416 p. (Atualidades pedagógicas). Tradução de Godofredo Rangel e Anísio Teixeira.

DEWEY, J. Experience and nature. George Allen and Unwin Ltd: Londres, 1929. 443p.

DEWEY, J. Interesse e esforço. In: Vida e educação. 10 ed. São Paulo: Melhoramentos, 1978. Tradução de Anísio S. Teixeira. Original: (Interest and effort in education).

DEWEY, J. Teoria da vida moral. Tradução de Leonidas Contijo de Carvalho. São Paulo: Abril Cultural, 1980b. Original: (Theory of moral life).

GHIRALDELLI Jr, P. O que é Filosofia Contemporânea. Col. Primeiros passos. São Paulo: Brasiliense, 2008.

HILL, Laurie Gertrude. Principles for Education of The Social Reconstructionists and Critical Theorists: A Yardstick of Democracy. 2006. 253 f. Tese (Doutorado) - Curso de Educação, Georgia Southern University, Statesboro, 2006. Disponível em: 
$<$ https://digitalcommons.georgiasouthern.edu/cgi/viewcontent.cgi?article=1461\&context=etd >. Acesso em: 02 maio 2019.

JAMES, W. The principles of psychology. New York: Cosimo, 2007. 689 p. Vol.1.

KILPATRICK, W. H. Remaking the curriculum. New York e Chicago: Newson And Company, 1936. 128 p.

KILPATRICK, W. H. The project method: the use of purposeful act in the educative process. The Teachers College Record. New York, p. 319-335. Set. 1918.

KILPATRICK, W. H. A Democracia e o respeito da personalidade. In: Democracia e educação. Washington: União Pan-americana, 1942.

KILPATRICK, W. H. A filosofia da educação de Dewey. Revista Brasileira de Estudos Pedagógicos. v. 17, n. 2, p.77-91, jan. 1953. Tradução de Célia Neves.

KILPATRICK, W. H. Educação para uma Civilização em Mudança. São Paulo: Melhoramentos, 1978.

KILPATRICK, W. H. Foundations of method: informal talks on teaching. New York: The Macmillan Company, 1925. 382 p.

KILPATRICK, W. H. Philosophy of education. New York: Macmillan, 1951. 465 p.

KILPATRICK, W. H. Selfhood and civilization: a study of the self-other process. New York: The Macmillan Company, 1941. 243 p.

KNOLL, M. A"I had made a mistake": William H. Kilpatrick and the Project Method. The Teachers College Record. New York, p. 1-45. Fev. 2012. Disponível em: <https://www.academia.edu/14351331/_I_had_made_a_mistake_William_H._Kilpatrick_and _the_project_method_2012_>. Acesso em: 10 jan. 2018.

LEITE, A. C. C. de A. A noção de projeto na educação: o método de projeto de William Heard Kilpatrick. São Paulo: Puc, 2007. Dissertação de mestrado.

LEMME, Paschoal. O Manifesto dos Pioneiros da Educação Nova e suas repercussões na realidade educacional brasileira. Revista Brasileira de Estudos Pedagógicos. Brasília, v.86, n.212, p.163-178, jan/abr.2005.

LOURENÇO FILHO, Manuel Bergstrom. Introdução ao estudo da escola nova: bases, sistemas e diretrizes da pedagogia contemporânea. 14. ed. Rio de Janeiro - Rj: Eduerj, 2002. $392 \mathrm{p}$.

PAGNI, P. A. Anísio Teixeira: experiência reflexiva e projeto democrático: a atualidade de uma filosofia da educação. Petrópolis, RJ: Vozes, 2008.

PAGNI, P. A. Anotações sobre a filosofia da educação de Anísio Teixeira. Conferência apresentada no GT de Filosofia da Educação. Anped. Disponível em:< http://23reuniao.anped.org.br/textos/te17.PDF >. Acesso em: 06 de mar. 2019.

PAGNI, P. A. Do manifesto de 1932 à construção de um saber pedagógico: ensaiando um diálogo entre Fernando de Azevedo e Anísio Teixeira. Ijuí, RS: UNIJUÍ, 2000. 344p.

PEIRCE, C. S. The essential Peirce: selected philosophical writings. Bloomington, 1998. 2 v. V.1

PIAGET, J. The Moral Judgment of the Child. New York: Harcourt-Brace, 1932.

SASS, Odair. Crítica da razão solitária: A psicologia social de George Herbert Mead. São Paulo: Puc, 1992. 269 p. Tese de Doutorado. 
SAVIANI, Dermeval. Escola e democracia. 37. ed. Campinas: Autores Associados, 2008. 112 p. (Coleção Educação Contemporânea).

SILVA, A. O. M e. Um estudo sobre a filosofia de William James. 2011. 179 f. Dissertação (Mestrado) - Curso de Filosofia, USP: São Paulo, 2011.

TANNER, D.; TANNER, L. History of the School Curriculum. New York: The Macmillan Company, 1990. 399 p.

TEIXEIRA, A. A pedagogia de Dewey. In: DEWEY, J. Vida e educação. 10 ed. São Paulo: Melhoramentos, 1978.

TEIXEIRA, A. Educação Progressiva: uma introdução à filosofia da educação. 2 ed. São Paulo: Companhia Editora Nacional, 1934.

TENENBAUM, S. William Heard Kilpatrick: trail blazer in education. New York: Harper and Brothers Publishers, 1951.

THORNDIKE, E. L. The original nature of man. In: Educational Psychology. New York: The Mason-henry, 1913a. 327 p. Vol. 1.

THORNDIKE, E. L. The psychology of learning. In: Educational Psychology. New York: The Mason-henry, 1913b. 452 p. Vol. 2.

WAAL, C. de. Sobre pragmatismo. São Paulo: Loyola, 2007. (título original: On Pragmatism. Tradução: Cassiano Terra Rodrigues.

WATSON, J. B. Behavior. New York: Henry Holt, 1914. p.351.

WEISS, A P. A theoretical basis of human behavior. Columbus: R.G. Adams, 1929. p.54. 